\title{
norden
}

\section{Perfluorinated alkylated substances (PFAS) in the Nordic environment}

\author{
Authors: \\ Roland Kallenborn, Norwegian Institute for Air Research (NILU) \\ Urs Berger, Norwegian Institute for Air Research (NILU) \\ Ulf Järnberg, Institute for Applied Environmental Research (ITM), \\ Stockholm University, Sweden \\ Contributing authors: \\ Maria Dam, Food, Veterinary and Environmental Agency of the Faroe Islands \\ Ola Glesne, Norwegian Pollution Control Authority \\ Britta Hedlund, Swedish Environmental Protection Agency \\ Juha-Pekka Hirvi, Finnish Environment Institute \\ Alf Lundgren, The Swedish Chemicals Inspectorate (representing the Nordic Chemicals \\ Group). \\ Betty Bügel Mogensen, National Environmental Research Institute of Denmark \\ Albert S. Sigurdsson, Environment and Food Agency of Iceland
}




\section{Perfluorinated alkylated substances (PFAS) in the Nordic environment}

TemaNord 2004:552

(C) Nordic Council of Ministers, Copenhagen 2004

ISBN 92-893-1051-0

ISSN 0908-6692

Nordic Council of Ministers

Store Strandstræde 18

DK-1255 Copenhagen K

Phone (+45) 33960200

Fax (+45) 33960202
Nordic Council

Store Strandstræde 18

DK-1255 Copenhagen K

Phone (+45) 33960400

Fax $\quad(+45) 33111870$

www.norden.org

\section{Nordic Environmental Co-operation}

Environmental co-operation is aimed at contributing to the improvement of the environment and forestall problems in the Nordic countries as well as on the international scene. The cooperation is conducted by the Nordic Committee of Senior Officials for Environmental Affairs. The co-operation endeavours to advance joint aims for Action Plans and joint projects, exchange of information and assistance, e.g. to Eastern Europe, through the Nordic Environmental Finance Corporation (NEFCO).

\section{The Nordic Council of Ministers}

was established in 1971. It submits proposals on co-operation between the governments of the five Nordic countries to the Nordic Council, implements the Council's recommendations and reports on results, while directing the work carried out in the targeted areas. The Prime Ministers of the five Nordic countries assume overall responsibility for the co-operation measures, which are co-ordinated by the ministers for co-operation and the Nordic Co-operation committee. The composition of the Council of Ministers varies, depending on the nature of the issue to be treated.

\section{The Nordic Council}

was formed in 1952 to promote co-operation between the parliaments and governments of Denmark, Iceland, Norway and Sweden. Finland joined in 1955. At the sessions held by the Council, representatives from the Faroe Islands and Greenland form part of the Danish delegation, while Åland is represented on the Finnish delegation. The Council consists of 87 elected members - all of whom are members of parliament. The Nordic Council takes initiatives, acts in a consultative capacity and monitors co-operation measures. The Council operates via its institutions: the Plenary Assembly, the Presidium and standing committees. 


\section{Table of contents}

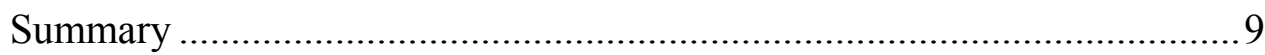

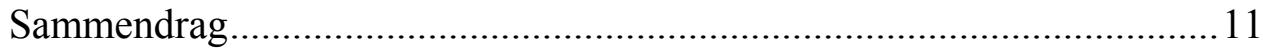

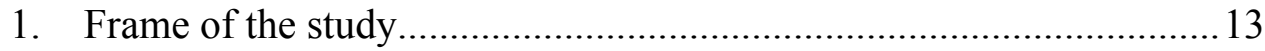

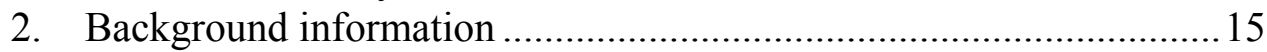

2.1. Applications and product information ....................................... 17

3. Samples for PFAS screening in the Nordic environment ................... 19

3.1. Sample selection: Criteria and priorities..................................... 19

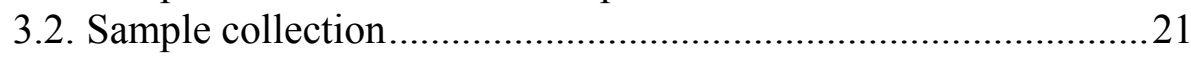

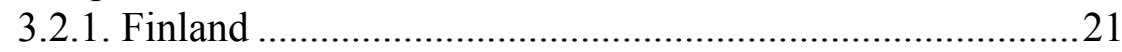

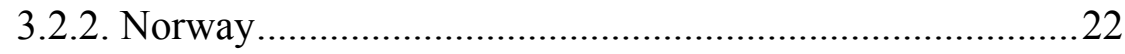

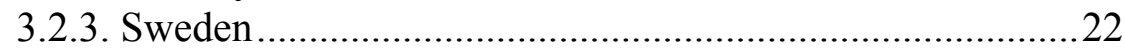

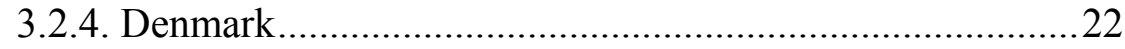

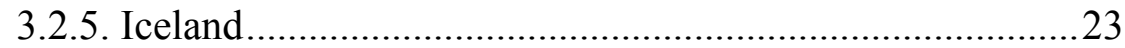

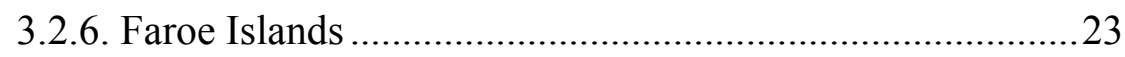

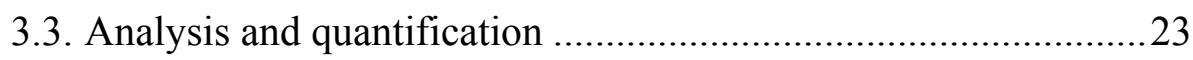

3.3.1. Preparation of sediment and sludge samples ................... 24

3.3.2. Preparation of water samples .......................................... 24

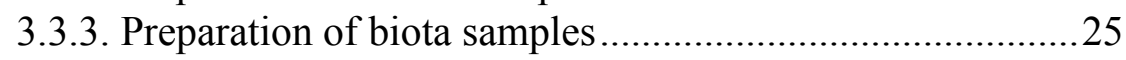

3.3.4. Quantification of abiota samples ......................................26

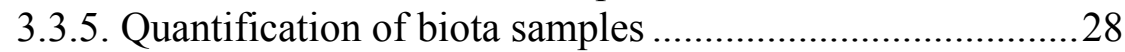

3.4. Quality control and method comparison.....................................28

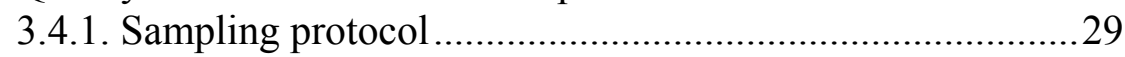

3.4.2. Limit of detection/ limit of quantification ......................... 30

3.4.3. Laboratory and field blanks .......................................... 30

3.4.4. Performance tests (parallel samples) ................................ 32

3.4.5. Laboratory intercomparison........................................... 33

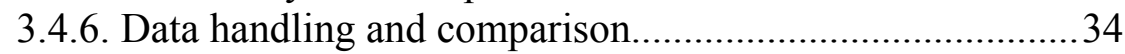

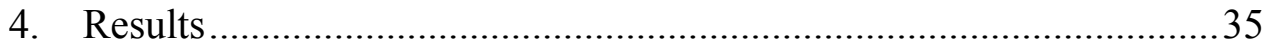

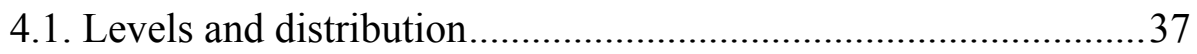

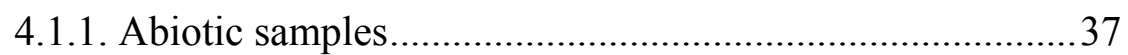

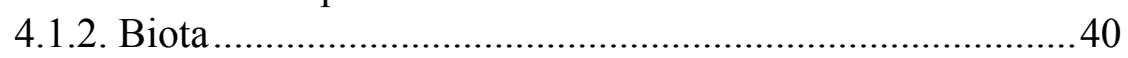

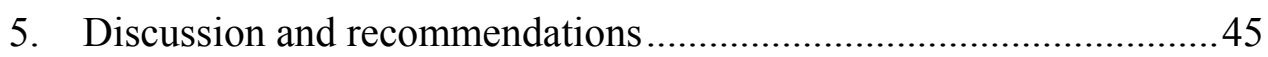

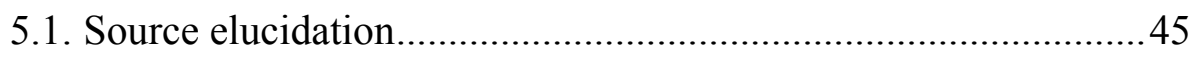

5.2. Sample specific patterns and fate estimation ..............................48

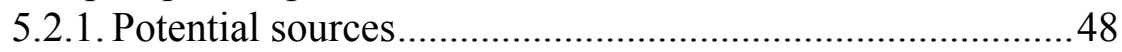

5.2.2. Seawater, fresh water and rain water samples...................49

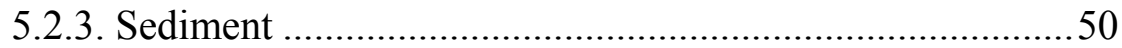

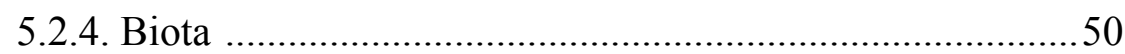

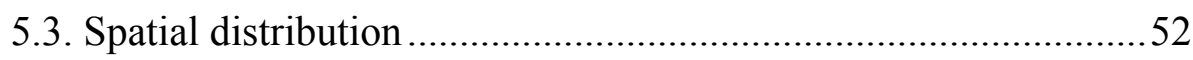

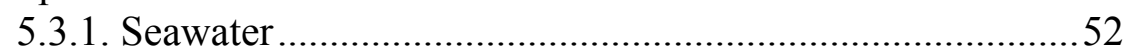

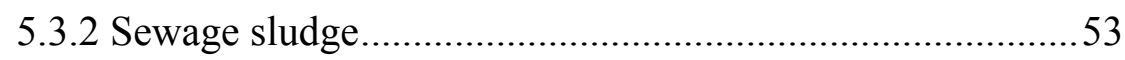

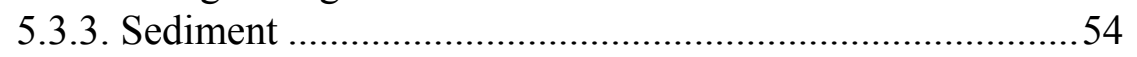




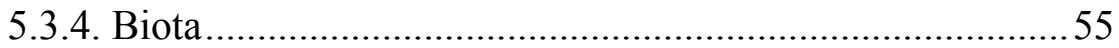

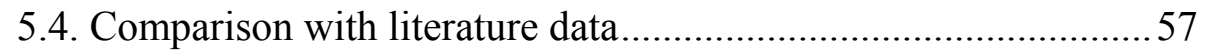

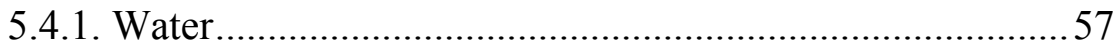

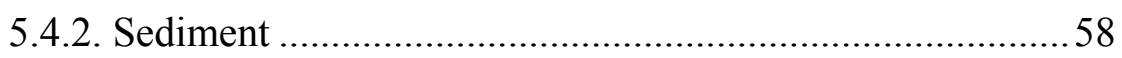

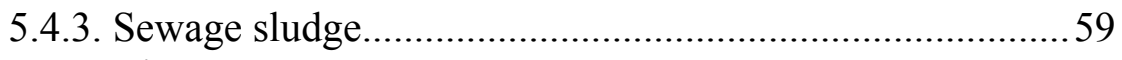

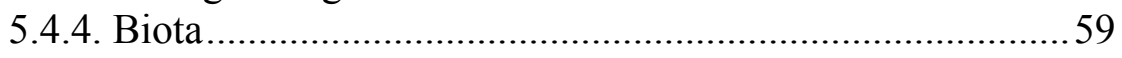

5.5. Level comparison with conventional "legacy" persistent

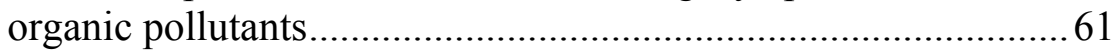

5.5.1. Concentration comparison in Seawater ............................. 61

5.5.2. Concentration comparison in Fresh water ..........................61 61

5.5.3. Concentration comparison in rain water ............................ 61

5.5.4. Concentration comparison in sediments ............................ 61

5.5.5. Concentration comparison in sewage effluent................... 62

5.5.6. Concentration comparison in sewage sludge..................... 62

5.5.7. Concentration comparison in landfill effluent................... 62

5.5.8. Concentration comparison in marine mammals ................ 62

5.5.9. Concentration comparison in marine fish.......................... 62

5.5.10. Concentration comparison in fresh water fish .................. 64

5.5.11. Concentration comparison in seabirds............................. 64

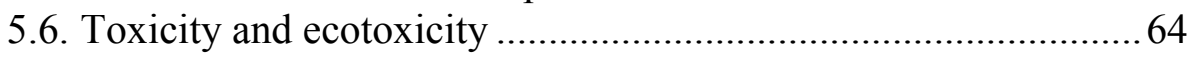

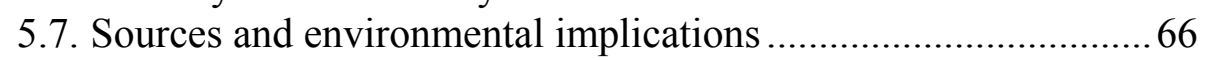

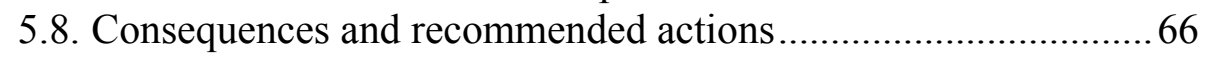

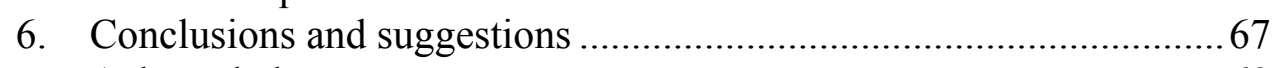

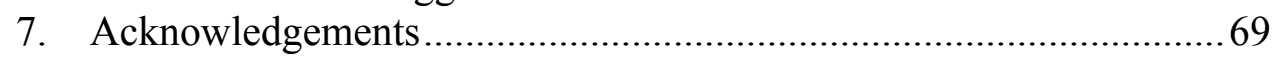

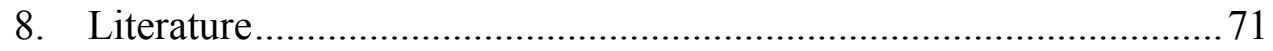

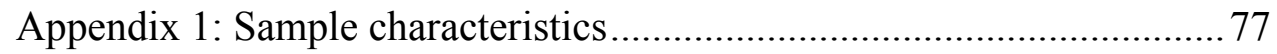

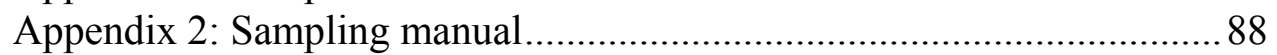

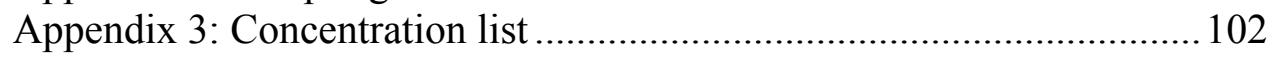

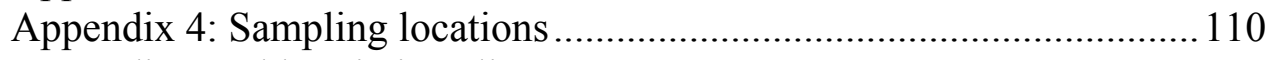

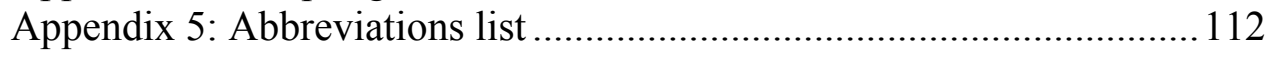




\section{Preface}

During the past decade, the identification of a new relevant group of environmental pollutants (i.e., perfluorinated alkylated substances $=$ PFAS) has opened a new chapter within the various disciplines of environmental sciences. A relatively rapid development within the field of instrumental trace analysis, in combination with increased public environmental awareness has led to new concepts in detection, evaluation and remediation of potentially hazardous chemicals in the environment.

However, the group of perfluorinated alkylated substances (PFAS), recently marked as already ubiquitously distributed around our globe, demands new evaluation tools with regard to the technical detection as well as risk evaluation. The unique physicochemical properties of the substance group are still a considerable challenge for environmental scientists as well as for regulatory authorities.

1.) The trace analysis of these compounds in environmental samples requires new highly sophisticated analytical instruments, such as high-performance liquid chromatography coupled to mass selective detectors in order to allow sufficient sensitive detections in the environment. Currently, these analytical methods, which are still under development, are suitable for research and method development but in most cases, not sufficiently validated for long-term monitoring in environmental compartments.

2.) PFAS residues are virtually both lipophobic and hydrophobic. In addition, these compounds express strong surface-active properties and usually adsorb strongly on natural surfaces. Thus, risk assessment tools, highly useful for conventional persistent organic pollutants (POPs), like the octanol-water partitioning coefficient $\left(\mathrm{K}_{\mathrm{OW}}\right)$ etc., are not suitable for evaluation of the environmental fate of PFAS residues.

3.) Due to the strong C-F binding in the PFAS molecule, most of these compounds are extremely persistent, virtually indestructible and are, thus, expected to prevail in the environment.

International regulatory authorities are currently discussing adequate measures to control and reduce the presence of PFAS related residues in the environment. The here presented report contribute to the world-wide efforts to evaluate and put in place suitable effective measures to reduce environmental hazards posed by PFOS and other relevant PFAS related chemicals.

\section{The project team}




\section{Summary}

The here presented screening study on occurrence, distribution and fate of perfluorinated alkylated substances (PFAS) and related chemicals in the Nordic environment revealed an ubiquitous distribution of perfluorinated contaminants. Six Nordic countries participated in the screening study (Denmark, Faroe Islands, Finland Iceland, Norway and Sweden). Compound specific distribution patterns in the different sample types confirmed that the physico-chemical properties in combination with release patterns and bioaccumulation potential are important and selective parameters for PFAS contamination.

High concentrations of PFAS related residues in sewage sludge and landfill effluents confirmed that these sample types are important primary anthropogenic sources for releases into the environment. Perfluorooctane sulfonate (PFOS) and perfluoroctanoic acid (PFOA) dominated in sewage sludge samples. Landfill effluent was highest contaminated of all aqueous samples. PFOA was dominating in landfill effluents. Lake water, seawater and rainwater (precipitation) samples were relatively low contaminated. However, measurable amounts of PFAS were found in all samples. The Nordic biota samples showed signals of species dependent distribution and levels. Highest PFAS levels were found in top predating Danish harbour seal (Phoca vitulina) samples with PFOS as predominant PFAS contaminant. However, in Faroe Island pilot whales (Globicephala melas), PFOSA and PFOS were dominating with up to $364 \mathrm{ng} / \mathrm{g}$ wet weight. Also Finnish and Norwegian pike samples (Esox lucius) are highly contaminated with PFOS (PFOS $=551 \mathrm{ng} / \mathrm{g} \mathrm{ww}$ ) demonstrating that also the freshwater ecosystem is contaminated with PFAS related chemicals. The patterns found in biota point towards both country specific release patterns and species depended up-take/ accumulation properties. The fact that PFOS and PFOSA were also detected in anadromous Arctic char in the Faroe Islands indicates that long-range transport in air and/or precipitation is occurring.

Thus, PFAS related chemicals are widely distributed in the Nordic environment. The presence of this type of compounds is generally confirmed for all environmental compartments. It is therefore recommended to include the relevant PFAS-related chemicals in environmental monitoring and consider further measures to reduce the burden of PFAS to the Nordic environment. 


\section{Sammendrag}

En første nordisk "screening"-undersøkelse om perfluorerte alkylerte stoffer (PFAS) med fokus på skjebne og fordeling av stoffene i miljøet, ble gjennomført med finansiell støtte av Nordisk ministerrådet (NMR). Seks nordiske land deltok i undersøkelsen (Denmark, Finland, Færøyene, Island, Norge og Sverige).

Komponent-spesifikke fordelingsmønstre i de ulike prøvetypene bekrefter at kjemiske egenskaper, i kombinasjon med utslippsmønster og akkumuleringspotensial er svært viktige parametre for opptak og spredning av PFAS i miljøet.

Høye nivåer av PFAS i kloakk og sigevannsprøver peker på at dette er viktige menneskeskapte primære kilder for utslipp og spredning av PFAS i det nordiske miljø. Perfluoroktansulfonat (PFOS) og perfluoroktansyre (PFOA) dominerer i kloakkprøvene fra alle seks nordiske land. I sigevannsprøvene (tatt fra lokaliteter i to nordiske land: Norge og Finland) dominerer PFOA. Sigevannsprøvene er betydelig høyere belastet med PFAS enn kloakkprøvene (opp til SUM PFAS = 1537 ng/g ww). Sammenlignet med kloakk og sigevann er PFAS nivåene i ferskvann (Mjøsa), saltvann og regnvann relativt lave. Men tilstedeværelsen av PFOS og PFOSA i anadrom røye fra Farøyene er en indikasjon for at atmosfærisk langtransport og nedbør er viktige kilder for PFAS i miljøet.

Indikasjoner for artspesifikke anrikningsmønster ble funnet i det biologiske materialet (16 ulike marine og ferskvann arter). Relativ høye PFAS-konsentrasjoner er påvist i marine og ferskvanns topp-predatorer. Høyest PFAS-belastning ble funnet i steinkobbe (Phoca vitulina) lever fra Danmark (PFOS $=551 \mathrm{ng} / \mathrm{g} \mathrm{ww})$, men også i grindhval (Globicephala melas) fra Færøyene var PFAS nivåene høyt (PWFAR09: PFOSA =364 ng/g ww). PFOS dominerte i selene, mens PFOSA var høyest konsentrert i grindhvallever.

I ferskvannsfisk ble det funnet høye konsentrasjoner av PFAS i gjedde (Esox lucius). Konsentrasjoner i ferskvannsfisk var sammenlignbart med nivåene detektert i marine topp-predatorer (PFOS $=551 \mathrm{ng} / \mathrm{g} \mathrm{ww}$ ). Også i lever fra gjedde var PFOS den dominerende PFAS komponenten.

Basert på resultatene fremlagt i denne rapporten kan det konkluderes at PFAS også finnes $\mathrm{i}$ betydelige konsentrasjoner $\mathrm{i}$ det nordiske miljø. I alle prøvetyper som er analysert ble det funnet PFAS. Det anbefales derfor å inkludere PFAS i nasjonale overvåkingsprogrammer vurdere ytterlige tiltak som kan redusere belastningen fra PFAS i miljøet. 


\section{Frame of the study}

A first screening project on the fate of perfluorinated alkylated substances (PFAS) in the Nordic environment was initiated by a project group with representatives of National Environmental Research Institute of Denmark, Finnish Environment Institute, Environment and Food Agency of Iceland, Food, Veterinary and Environmental Agency of the Faroe Islands, Norwegian Pollution Control Authority and Swedish Environmental Protection Agency. The project was financed and supported by the Nordic Council of Ministers through the Nordic Chemicals Group and the Nordic Monitoring and Data Group as well as the participating institutions.

The respective participating Nordic countries organized sample selection, collection and transport based on a sample protocol and manuals provided by the analytical laboratories. Sample preparation, trace analysis and quantification were performed jointly by the Norwegian Institute for Air Research (NILU, Kjeller, Norway) and the Institute for Applied Environmental Research (ITM, Stockholm, Sweden). For this first screening, six PFAS related chemicals with potential for accumulation in the environment were chosen. In addition, the analytical laboratories voluntarily added two PFAS compounds (PFBS and PFDS,) to the list of target chemicals (table 1).

The selected PFAS related compounds were chosen due to the following priority criteria:

- Perfluorooctane sulfonate (PFOS) and perfluorooctanoic acid (PFOA) are the two compounds best documented of all PFAS related compounds so far with regard to environmental hazards. PFOS and PFOA, thus, are the major motivation for the presented screening project.

- Perfluorooctane sulfonamide (PFOSA) is suspected to be a major precursor of PFOS in the environment.

- Perfluorobutane sulfonate (PFBS), perfluorohexane sulfonate (PFHxS) and perfluorodecane sulfonate (PFDS) are expected to be found in the environment due to their similar structure compared with PFOS. However only sparse information about environmental properties and toxicity is available yet. In addition, PFBS is announced as successor for PFOS-related products.

- Perfluorohexanoic acid (PFHxA), perfluoroheptanoic acid (PFHpA) and perfluorononanoic acid (PFNA) are expected to be present in the environment due to their resemblance with PFOA. However, only sparse information about environmental properties and toxicity is available yet.

For most of the substances included, indications existed already for their occurrence in the environment. The expected results will allow assessing the existing level of contamination (spatial distribution monitoring) and indicating regional differences. This spatial screening programme will enable the determination of the representativeness of the monitoring sites with regard to spatial variability in contaminant concentrations and 
will give valuable information about the ubiquity of PFAS distribution in the Nordic countries.

Table 1: Selected PFAS related chemicals chosen for the presented Nordic screening programme.

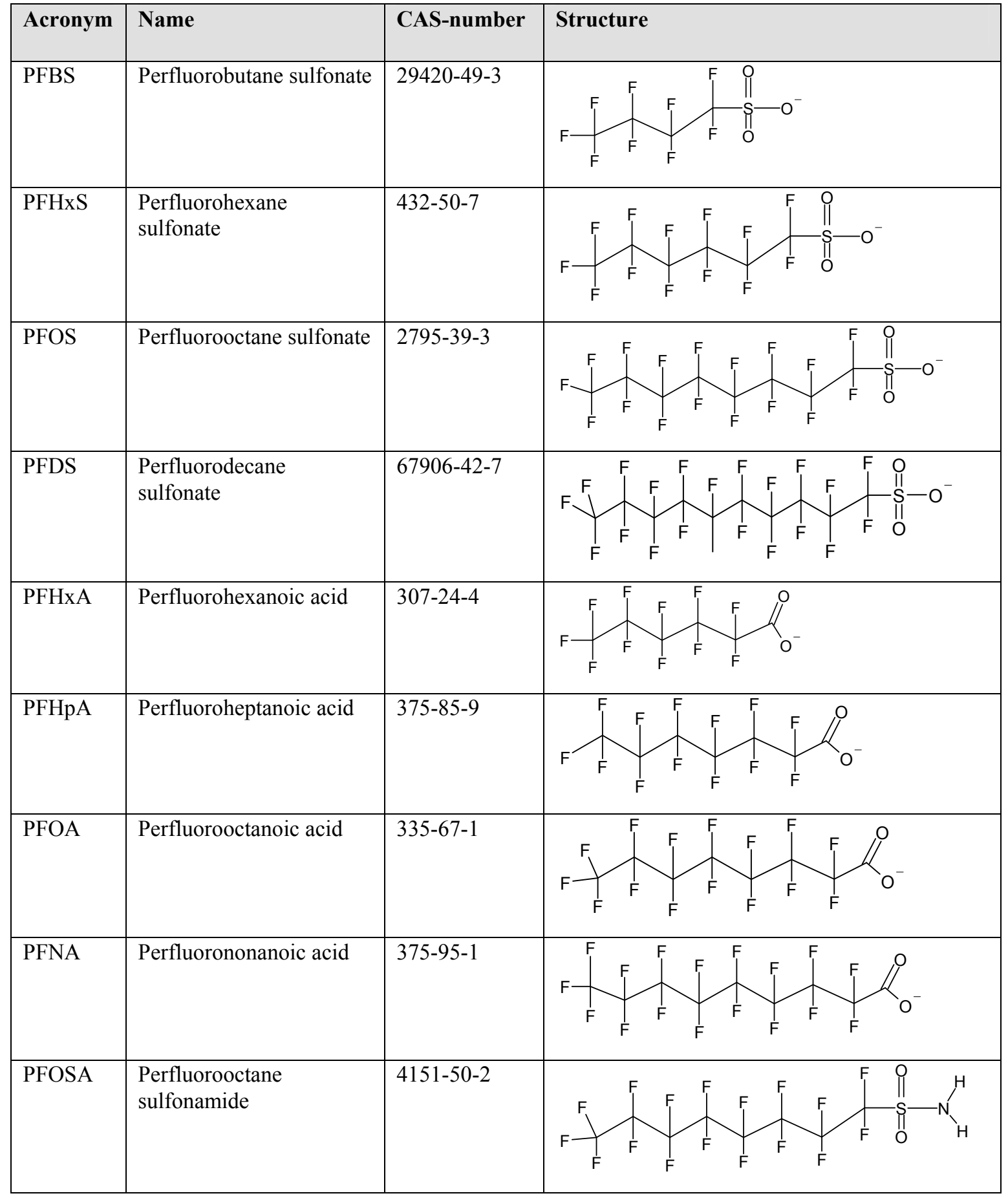




\section{Background information}

Within the past 50 years, industrial application as well as consumer uses of perfluorinated alkylated substances (PFAS) such as perfluorooctane sulfonate (PFOS) and perfluorooctanoic acid (PFOA), as well as their related products have increased tremendously.

Perfluorinated compounds are commonly produced by electrochemical fluorination (ECF). As starting reaction for the production of PFOS related chemicals, the $3 \mathrm{M}$ corporation has introduced the fluorination of 1-octanesulfonyl fluoride to perfluorooctanesulfonyl fluoride (POSF), described in figure 1 (Anonymous, 1999).

\begin{tabular}{|c|c|c|}
\hline $\mathrm{C}_{8} \mathrm{H}_{17} \mathrm{SO}_{2} \mathrm{~F}+17 \mathrm{HF}$ & $4.5-7.0 \mathrm{~V}$ & $\mathrm{C}_{8} \mathrm{~F}_{17} \mathrm{SO}_{2} \mathrm{~F}+17 \mathrm{H}_{2}$ \\
\hline $\begin{array}{l}\text { 1-Octanesulfonyl } \\
\text { fluoride }\end{array}$ & $\mathrm{ECF}$ & $\begin{array}{l}\text { Perfluorooctanesulfonyl } \\
\text { fluoride (POSF) }\end{array}$ \\
\hline
\end{tabular}

Figure 1: Industrial formation of PFAS related chemicals via ECF (Anonymous, 1999).

Perfluorooctanesulfonyl fluoride (POSF) is thereafter used as starting chemical for a huge variety of different products within the PFAS group used in a vast array of products and applications. ECF produced PFAS related substances usually are containing a sulfonyl- or carboxylic group in their molecular structure.

During the past decades, consumers in western countries embraced these chemical products as important chemical tools for all types of household related processes (e.g., cooking, clothing, furniture, etc.) as described in a comprehensive report (Hekster et al. 2002). The chemicals of the PFAS group are characterized by carbon chains with variable lengths, to which fluorine atoms are covalently bonded. The strong C-F bond is yielding ultimately in virtually indestructible chemicals that until recently were thought to be completely biologically inert and, thus, not bioavailable for biochemical processes.

Since the late 1990s, increasing numbers of published scientific studies, pinpointing the potential environmental hazards posed by this type of chemicals, have brought PFAS related chemicals in the focus of international public environmental concern. Besides being an important industrial group of compounds, PFAS related residues are today considered as highly toxic, extraordinarily persistent chemicals that pervasively contaminate human blood and wildlife all over the world. In contrast to welldocumented persistent organic pollutants like polychlorinated biphenyls (PCB), chlorinated- $p$-dibenzodioxins and furans $(\mathrm{PCDD} / \mathrm{F})$, governments and scientists are today especially concerned that the most pervasive and toxic members of the PFAS group will never degrade in the environment.

Already in 2000, the U.S. Environmental Protection Agency (EPA) banned PFOS from the US market. Shortly thereafter, the manufacturer $3 \mathrm{M}$ also stopped voluntarily the 
production of PFOA. Currently, PFOA is also evaluated for regulatory actions by U.S.EPA.

The production of sulfonyl-based fluorochemicals has recently been estimated around 6.5 million pounds world-wide only for the year 2000 (U.S. Environmental Protection Agency 2000). For PFOS only, a global production volume of 831 metric tons are estimated for the year 2000 (Anonymous 2002). Current environmental studies confirmed that PFAS are shown to be globally distributed, environmentally persistent and bioaccumulative (van de Vijer et al. 2003, Kannan et al. 2001 a,b, 2002 a,b, Giesy and Kannan 2001, Martin et al. 2004) with implication also for human exposure (Olsen et al. 2003, Taniyasu et al. 2003, Levitt \& Liss 1986).

Under the joint leadership of UK and USA, the OECD co-operation on the Investigation of Existing Chemicals group performed a first risk assessment on PFOS and its salts in 2002 concluding that PFOS is persistent, bioaccumulative and toxic to mammalian species (Anonymous 2002). There are species differences in the elimination half-life of PFOS; the half-life is 100 days in rats, 200 days in monkeys, and years in humans. The toxicity profile of PFOS is similar among rats and monkeys. Repeated exposure results in hepatotoxicity and mortality (Anonymous 2002).

Also the Swedish Chemicals Inspectorate performed a preliminary national study on the risk evaluation status and possible national risk mitigation strategies in Sweden and other European countries on PFOS and its salts (Cederberg et al. 2004). The document reports on the strategy of the UK Department for Environment; Food and Rural Affairs (DEFRA) and the UK Environment Agency to develop a risk evaluation manual on PFOS and its potential to degrade under natural conditions (Brook et al. 2004). Based on this study, in UK the main application areas of PFOS and related compounds are as follows:

Impregnation/ waterproofing of textiles and fur products: $49 \%$ (195 tons in 2001)

Impregnation/ waterproofing of paper related products : $15 \%$ (60 tons in 2001)

Outdoor activities: $18 \%$ (70t in 2001)

Flame retardants: $16 \%(65 \mathrm{t}$ in 2001$)$

Others: $2.5 \%$ (10 tons in 2001)

The European Union plan to adopt the resolutions according to the UK lead work on risk evaluation on PFOS and related compounds.

Also in the Netherlands a first evaluation of environmental risk posed by PFOS and related compounds revealed than $60-105$ tons/y (2002) are released through various products (Hekster et al. 2002).

Already in the 1980s, the acute toxicity of perfluorooctanoic acid (PFOA) and nonadecafluoro- $n$-decanoic acid (NDFDA) was evaluated in male Fischer rats (Olsen \& Andersen 1983) and human B cells (Levitt \& Liss 1986). In both studies toxic potency for PFOA and NDFDA was reported. Some of the toxic effects found for NDFDA were remarkably similar to those known for 2,3,7,8-tetrachlorodibenzo- $p$-dioxin (TCDD). It was assumed that the acute toxicity of NDFDA might be due to the ability to interfere with fatty acid metabolism. Thus, further studies of its toxicity have been recommended as valuable in understanding toxicological mechanisms of action of TCDDs as well.

Due to the well-documented environmental concerns related to PFAS, the $3 \mathrm{M}$ Cooperation (St Paul, MN, USA) decided to discontinue its product line for most of the PFOS related products with the effective end of production occurring already around 
November 2001. In addition US-EPA has initiated regulation actions with respect to PFOS-related chemicals. However, the EPA's initial actions and 3M's phase out apply only to PFOS and its derivatives. Telomer-based PFAS (e.g. fluorotelomer alcohols) will continue to be produced and no disruption of supplies will or has been experienced so far. These telomer-based PFAS related compounds are chemical products of a telomerisation process where tetrafluoroethylene (TFE) as "building blocks" is used resulting in fluorinated alcohols with varying alkyl-chain length and usually one nonfluorinated carbon atom behind the hydroxylated final carbon atom.

US-EPA is currently assessing other perfluorinated chemicals like PFOA and related chemicals such as telomer products (Fluorotelomer alcohols: FTOH) with regard to possible environmental hazards and respective regulatory actions.

Currently, international research is concentrating on assessing the mechanisms of PFOS toxicity, identifying the full range of impacts in order to get a comprehensive understanding of contamination levels in the environment incl. people and wildlife.

Most of the selected PFAS compounds chosen for the presented screening exercise, are neither water nor lipid soluble, except for PFOSA, which is found to be surprisingly lipophilic and, thus, is expected to accumulate in the course of the food webs. Thus, relatively high levels were found in all biota samples.

\subsection{Applications and product information}

A first survey of the product and application information available in the respective Nordic countries revealed that the excess of actual date is still difficult and often impossible for PFAS related compounds.

Norway is currently working on a material flow analysis. The preliminary estimates shows that fire fighting foams cover more than half the total PFOS-related substances and other PFAS used in the country. In protective coating and textiles the amounts is less than half of the total. In floorwax/polish and electronic industries the amounts are approximately 100-200 kg. The total amount for PFAS used in Norway is estimated with approximately $23-26$ tons. However, there may be considerable uncertainties in these estimates (personal com., Ola Glesne).

The total sales of PFOS based chemicals to the Swedish market in 1999 was 38 tons $(3 \mathrm{M}$, personal com.) most of which was used in textile and leather treatment and as industrial surfactant. 


\section{Samples for PFAS screening in the Nordic environment}

Based on recently raised concerns about possible environmental impact of perfluorinated residues in pristine environments including Northern regions, the NTEM "Nordic Chemicals Group" of the Nordic Council of ministers has initiated a first screening on the presence and distribution of selected perfluorinated alkylated substances (PFAS) in the Nordic environment.

\subsection{Sample selection: Criteria and priorities}

Based on already available scientific information on distribution and concentration levels, the NTEM "Nordic Chemistry group" in co-operation with the analytical laboratories in charge, the Norwegian Institute for Air Research (NILU, Kjeller, Norway) and the Institute for Applied Environmental Research (ITM, Stockholm, Sweden) selected a priority list of 6 compounds of the PFAS group (see table 1). In addition, the analytical laboratories have voluntarily added two priority compounds:

Perfluorobutane sulfonate (PFBS): This compound is announced as official successor for the PFOS related products by the manufacturers. According to the manufacturers, PFBS is not accumulating in biota. In accordance with this postulation, no PFBS traces were confirmed in biota samples yet.

Furthermore, perfluorodecane sulfonate (PFDS) has been included in the PFAS screening of biological samples.

A comprehensive selection of sample types spanning from seawater and precipitation towards marine mammals, as representatives for top predators, have been selected by NTEM, the working group of the Nordic council of Ministers.

Sampling locations are presented in two separate maps for sites were biota and abiotic samples were collected (see appendix 4).

For the abiotic environment, 7 sample types have been analysed and for the biotic environment, 16 species have been selected, representing freshwater and marine environments (table 2). Exclusively liver samples were analysed except for the fulmars from the Faroe Islands were eggs samples were pooled. The sample characteristics for the material provided by the 6 participating Nordic countries can be found in appendix 1. 
Table 2: Sample types selected for the first Nordic PFAS screening.

\begin{tabular}{|c|c|c|c|c|c|c|c|}
\hline & Finland & Sweden & Norway & Danmark & Iceland & aroe Island & SUM samples \\
\hline \multicolumn{8}{|l|}{ ABIOTA } \\
\hline Seawater & 4 & 0 & 0 & 3 & 1 & 3 & 11 \\
\hline Rainwater & 2 & 3 & 0 & 0 & 0 & 0 & 5 \\
\hline Landfill effluent & 1 & 0 & 5 & 0 & 0 & 0 & 6 \\
\hline Sewage effluent & 2 & 0 & 2 & 0 & 0 & 1 & 5 \\
\hline Sediment & 3 & 3 & 3 & 0 & 1 & 3 & 13 \\
\hline Sewage sludge & 4 & 3 & 2 & 3 & 2 & 1 & 15 \\
\hline Lake water & 0 & 0 & 4 & 0 & 0 & 0 & 4 \\
\hline \multicolumn{8}{|l|}{ BIOTA } \\
\hline Flounder & 0 & 0 & 0 & 4 & 0 & 0 & 4 \\
\hline Eelpout & 0 & 0 & 0 & 1 & 0 & 0 & 1 \\
\hline Herring & 0 & 0 & 0 & 1 & 0 & 0 & 1 \\
\hline Harbour seal & 0 & 0 & 0 & 5 & 0 & 0 & 5 \\
\hline Grey seal & 0 & 3 & 0 & 0 & 0 & 0 & 3 \\
\hline Pike & 8 & 0 & 1 & 0 & 0 & 0 & 9 \\
\hline Sculpin & 0 & 0 & 0 & 0 & 1 & 2 & 3 \\
\hline Dab & 0 & 0 & 0 & 0 & 1 & 2 & 3 \\
\hline Cod & 0 & 8 & 0 & 0 & 0 & 1 & 9 \\
\hline Arctic char & 0 & 0 & 0 & 0 & 0 & 2 & 2 \\
\hline Trout & 0 & 0 & 1 & 0 & 0 & 0 & 1 \\
\hline Pilot whale & 0 & 0 & 0 & 0 & 0 & 4 & 4 \\
\hline Fulmar & 0 & 0 & 0 & 0 & 0 & 2 & 2 \\
\hline Long-rough dab & 0 & 0 & 0 & 0 & 2 & 0 & 2 \\
\hline Minke whale & 0 & 0 & 0 & 0 & 5 & 0 & 5 \\
\hline burbot & 0 & 0 & 1 & 0 & 0 & 0 & 1 \\
\hline Perch & 0 & 4 & 1 & 0 & 0 & 0 & 5 \\
\hline SUM per country & 24 & 24 & 20 & 17 & 13 & 21 & 119 \\
\hline
\end{tabular}

The following marine and freshwater species were analysed for PFAS residues:

\section{Marine fish:}

Flounder (Platichthys flesus)

Eelpout (Zoarces viviparous)

Herring (Clupea harengus)

Shorthorn Sculpin (Myoxocephalus scorpius)

Dab (Limanda limanda)

Long-rough dab (Hippoglossoides platessoides)

Atlantic cod (Gadus morhua)

\section{Freshwater fish:}

Pike (Esox lucius)

Trout (Salmo trutta)

Arctic char (Salvelinus alpinus)

Perch (Perca fluviatilis)

Burbot (Lota lota)

\section{Marine mammals:}

Harbour seal (Phoca vitulina)

Grey seal (Halichoerus grypus)

Pilot whale (Globicephala melas)

Minke whale (Balaenoptera acutorostrata)

Marine birds:

Fulmar (Fulmarus glacialis) 
A total of 119 samples have been analysed covering a large and challenging variety of matrices. In addition, 13 abiotic and 3 biota samples have been collected as parallel samples in order to provide information about method robustness and variability (table $3)$.

Table 3: Parallel samples for method performance tests collected in all six participating Nordic countries*

\begin{tabular}{|c|c|c|c|c|c|c|c|c|c|c|c|c|c|}
\hline & Noway & & Finland & & Sweden & & Danmark & \multicolumn{3}{|c|}{ Faroe Islands } & Iceland & \\
\hline Sample type & samples & parallels & samples & parallels & samples & parallels & samples & parallels & samples & parallel & samples & parallels & SUM parallels \\
\hline Seawater & & & & & & & SWDANO2 & 2 & & & SWICE01 & 4 & 6 \\
\hline Rainwater & & & & & RWSWE01 & 2 & & & & & & & 2 \\
\hline Lake water & LWNOR04 & 2 & & & & & & & & & & & 2 \\
\hline Landfill effluent & LFNOR05 & 2 & LFFIN07 & 3 & & & & & & & & & 5 \\
\hline Sewage effluent & SENOR11 & 2 & SEFIN09 & 2 & & & & & & & & & 4 \\
\hline Sediment & & & SDFIN10 & 3 & & & & & & & SDICE02 & 5 & 8 \\
\hline Sewage sludge & & & SSFIN14 & 3 & & & & & & & SSICE03+04 & 4 & 7 \\
\hline Fresh water fish & & & & & PESWE3 & 2 & & & ACFAR06 & 2 & & & 4 \\
\hline Marine fish & & & & & & & & & & & LDICE01 & 3 & 3 \\
\hline Sum samples & 3 & 6 & 2 & 5 & 2 & 4 & 1 & 2 & 1 & 2 & 4 & 16 & 41 \\
\hline
\end{tabular}

* Sample characteristics can be found in appendix 1

\subsection{Sample collection}

As a guideline for appropriate sampling, the laboratories in charge provided a sampling manual for the sampling personnel in the Nordic countries participating in the screening exercise (Appendix 2). Detailed procedures for sampling, storage and transport were given. Sampling protocols for all sample types were implemented in the sampling manual.

Detailed information on the sampling locations are provided by the respective participating countries (see also appendix 1):

\subsubsection{Finland}

\section{Abiotic samples:}

The waste water (sewage) treatment plants of Espoo, Helsinki and Porvoo are the biggest plants in Finland taking care of both industrial and municipal waste waters. The treatment systems are of the most modern quality and technique in Finland. In the plants there are treated the following amounts of waste water given in peq -values: Espoo $=235000$ person equivalent (peq), Helsinki $=815000$ peq, Porvoo $=170000$ peq.

The landfill effluent studied was collected from the very large Waste Treatment Centre in Espoo, s.c. Ämmässuo landfill.

The solid wastes are collected from the city areas of Helsinki, Espoo, Vantaa, Kauniainen and Kirkkonummi having the population over one million. The amount of waste received in 2002 was calculated to 670000 tons.

\section{Biota:}

All Finnish pike samples were caught in the coastal water near the main urban city area of Helsinki (old City bay) about 200-500 $\mathrm{m}$ from the coastline. The area has influences 
of polluted waters and sediment deposits since industrial PFA-substances were introduced into use.

\subsubsection{Norway}

\section{Abiotic samples:}

The sampling of landfill effluents was performed on the vicinity of 5 landfill locations situated close to the Kristiansandfjord and the Oslofjord area. The landfill sites were selected in co-operation with the Norwegian State Pollution Control Authorities (SFT). Local-co-operation partners and scientists from the Norwegian Centre for Soil and Environmental Research (Jordforsk) suggested priority sites and the scientists of the institute prepared the sampling equipment. Samples were collected during the period July - October 2003. The rest of the abiotic samples were all collected in Lake Mjøsa or at sewage treatment plants with effluents to the lake (Appendix 1).

\section{Biota:}

All freshwater fish samples were collected from the Norwegian Lake Mjøsa close to sewage treatment plants or potential source locations by scientists of the Norwegian Institute for Water Research (NIVA).

\subsubsection{Sweden}

\section{Abiotic samples:}

Rain water samples were collected from the Råö research station. Sampling periods: RWSWE01: 02.10.2003 -11.11.2003, RWSWE02: 11.11.2003 - 03.12.2003., RWSWE03: 03.12.2003-15.12.2003. The freshwater sediment samples were collected from potential accumulation sited upstream and downstream the municipality of Kristianstad. Representative sewage sludge samples were collected over an entire week with representative daily sampling and unification after one week (week 39, 2003). Sewage was collected from the Sewage treatment plants (STP) Kistianstad Centrala ARV, Köpinge ARV and Tollarp (supposedly household waste water only).

\section{Biota:}

Freshwater fish (Perch) was collected close to the freshwater sediment sites at the potential accumulation sitein the vicinity of the STP Kristianstad. Pooled samples containing in average 10 livers were provided. Atlantic cod were collected from one near shore site and one off-shore site (Hanöbukten, Hoburgen). Grey seal samples stem from three different locations from the Swedish Baltic coast (Gästrikland, Uppland, Sörmland)

\subsubsection{Denmark}

\section{Abiotic samples:}

Aqueous and solid abiotic samples were collected in the vicinity of potential sources. Sewage sludge samples were chosen from large sewage treatment plants from the cities of Roskilde (Sewage treatment plant (STP) Bjergmarken), Odense (STP Stige) and Copenhagen (STP Lynetten). Seawater samples were collected in coastal areas close to the city of Rinkøbing. Sampling sites for sweater sampling close to the seage effluent of 
Copenhagen (STP Lynetten), Odense (S1: Sedenstrand) were chosen. As reference site, the station 60 (st.60) situated relatively remote to effluent influences was also sampled.

\section{Biota:}

All biota samples were collected in the vicinity of potential primary PFAS sources. Flounders were caught in the coastal water close to the capitol Copenhagen. Eelpout and herring were collected in the inner part of the Roskilde fjord. The harbour seal samples were collected close to settlements (Limfjord, Hesselø, Samsø and Øresund).

\subsubsection{Iceland}

\section{Abiotic samples:}

Sediment and seawater samples were collected close to the landfill site Gufunes. Sewage sludge was sampled from the two STPs Klettagardar and Ananaust.

\section{Biota:}

The Icelandic Minke whale samples were collected during a research expedition in the period August/ September 2003 in the North Atlantic waters (appendix 1). All marine fish samples were collected close to city of Reykjavik (capitol of Iceland). Long-rough dab, dab and sculpin samples were collected in the harbour areas of Reykjavik, close to potential PFAS sources (e.g.,Gufunes landfill).

\subsubsection{Faroe Islands}

\section{Abiotic samples:}

Seawater, Sewage effluent, Sediment and Sewage sludge was collected from sites close to potential PFAS sources. Seawater samples were collected from the harbour area of Torshavn city (the capitol of the Faroe Islands). Two sediment samples were collected in the Torshavn harbour area and nearby Kaldbaksfjord. Sewage sludge was sampled from the STP Sersjantvikin in Torshavn.

\section{Biota:}

Pilot whales were caught near shore at Sandagerdi in September 2002. The Arctic char samples stem from a landlocked population in a freshwater lake (á Mýranar). The fulmar eggs were collected from a bird cliff at Vidareidi. The Atlantic cod, sculpin and dab samples were collected in coastal waters close to settlements (Kaldbak, Kirkjubö and Torshavn)

\subsection{Analysis and quantification}

All samples were sent by the national institution responsible for sampling directly to the analytical laboratories responsible according to the procedure described in the sampling manual (Appendix 2). The abiotic samples (sea water, precipitation, sediment, sewage sludge, landfill effluent, sewage effluent and freshwater) were sent for analysis to the laboratories of the Norwegian Institute for Air Research (NILU, Kjeller, Norway), whereas the biological samples (16 species) were analysed by the Institute for Applied Environmental Research (ITM, Stockholm, Sweden). 


\subsubsection{Preparation of sediment and sludge samples}

All samples were stored at $6{ }^{\circ} \mathrm{C}$ prior to sample preparation. No water content in sediment and sludge samples was determined. According to the supplement to the sampling manual (Appendix 2), the sewage and sediment samples should be sent to the laboratory in pre-tried or desiccated conditions. However, not all samples have been sent as required. Therefore, the samples were partly dried by filtering using a water-jet vacuum pump prior to analyses to ensure comparable sample conditions. Thereafter, quantification was based on a wet weight basis including the remaining water in the solid samples. Sediment and sludge samples were extracted using accelerated solvent extraction (ASE, Dionex, Sunnyvale, CA).

A stainless steal (11 ml volume) ASE cell was used for extraction. About $2 \mathrm{~g}$ rinsed and pre-cleaned sea sand (rinsed with methanol, then $200{ }^{\circ} \mathrm{C}$ for $4 \mathrm{~h}$ ) was filled in bottom of the cell. Thereafter, approx. $5 \mathrm{~g}$ sample was transferred into ASE cell. Finally, the ASE extraction cell was completely filled with sea sand. Prior to extraction, $50 \mu 1$ internal standard (ISTD) was added according to the standard listed in table 4.

Table 4: Internal and recovery standards used for PFAS quantification in aqueous samples, sediment and sludge

\begin{tabular}{|l|l|}
\hline $\begin{array}{l}\text { Internal quantification standard } \\
\text { (ISTD) }\end{array}$ & Recovery standard (RSTD) \\
\hline $\begin{array}{l}0.1 \mathrm{ng} / \mu \mathrm{l} \\
(7 \mathrm{H}-\mathrm{PFH} \text {-perfluoroheptanoic acid }\end{array}$ & $\begin{array}{l}0.2 \mathrm{ng} / \mu \mathrm{l} \text { 3,5-bis(trifluoromethyl)phenyl } \\
\text { acetic acid in methanol }\end{array}$ \\
\hline
\end{tabular}

Accelerated solvent extraction (ASE) was performed three times with methanol (17 $\mathrm{min} /$ cycle, $150{ }^{\circ} \mathrm{C}, 2000 \mathrm{psi}$ ). The three extracts were combined in a Turbovap container (Zymark, Hopkinton, MA, USA) and concentrated with a Turbovap evaporator to approx. $500 \mu \mathrm{L}$. Final concentration to $200 \mu \mathrm{L}$ took place under gentle nitrogen stream $\left(\mathrm{N}_{2}, 5.0\right.$ quality, Hydrogas, Porsgrunn, Norway).

Subsequently, $50 \mu \mathrm{L}$ of recovery standard (see table 4) and $250 \mu \mathrm{L} 4 \mathrm{mM}$ ammonium acetate buffer (in deionised water) was added. The closed sample vials were treated for 10 minutes in an ultrasonic bath. In order to remove precipitation, the samples were filtrated using a Microcon YM-3 centrifugal filter device (Millipore Corp., Billerica, MA) at 14000 rounds per minutes (rpm) for $45 \mathrm{~min}$. finally, aliquots of the sample extract were transferred into autoinjector vials for quantification with high-performance liquid chromatography coupled to mass spectrometric detection.

\subsubsection{Preparation of water samples}

About $500 \mathrm{ml}$ of the collected water samples were used for PFAS analysis. Approx. 0.5 vol.-\% formic acid ( $\mathrm{HCOOH}, 2.5 \mathrm{ml}$ for $500 \mathrm{ml}$ water) was added to prevent uncontrolled microbiological degradation processes. As a first sample preparation step, the water samples were filtered (using a water-jet vacuum pump) through a glass fibre 
filter (GFF: $142 \mathrm{~mm}$, PALL Life Sciences, New York, USA, cat. no. 61635). GFF and aqueous sample are, thereafter separately prepared for analysis.

The GFF was folded into an $11 \mathrm{~mL}$ ASE-extraction cell. $50 \mu$ ISTD (table 4) was added and extraction is performed according to the ASE method described earlier for sediment and sludge samples.

For water analysis, $80 \mathrm{mg}$ ammonium acetate (approx. $2 \mathrm{mM}$ ) and $50 \mu \mathrm{l}$ ISTD was added. Finally the sample bottle (PET or PP) containing the water samples was weighed prior to solid phase extraction (SPE) using an analytical balance.

For solid phase extraction (SPE), HLB Plus SPE cartridges (0.25 g, Waters cooperation) were used. Prior to extraction, the SPE system was rinsed with approx. $20 \mathrm{ml}$ methanol. The cartridge was thereafter conditioned using about $10 \mathrm{ml}$ Milli-Q water. The water samples were extracted through the SPE cartridge with approx. 2 drops/sec. After sample extraction, the empty bottle (still containing small amounts of residual water) was again weighed. The weight difference is used as sample amount for concentration calculation.

Prior to elution, the SPE cartridge was rinsed with $2 \mathrm{~mL}$ methanol/water (40/60). PFAS elution is performed with $8 \mathrm{~mL}$ methanol. The methanol extract was, thus, concentrated to $200 \mu \mathrm{l}$ by a combination of Turbovap and nitrogen concentration (see method description for sludge and sediment sample preparation) and $200 \mu \mathrm{l}$ of a $4 \mathrm{mM}$ solution of ammonium acetate in water was added.

Both filter and aqueous sample extracts were finally spiked with $50 \mu \mathrm{RSTD}$, filtered if necessary as described for sediment and sludge extracts (in case of precipitation) and transferred to autoinjector vials for subsequent HPLC/MS analysis and quantification

\subsubsection{Preparation of biota samples}

As appropriate target tissue in all fish and marine mammal samples, liver was chosen. All samples were collected according to the sampling manual provided (appendix 2). The collected samples were thereafter send to the analytical laboratory (ITM) for quantification. The tissue samples were thoroughly homogenized before preparation of aliquots for analysis. Liver samples in excess of a total of $40 \mathrm{~g}$ were homogenized using a Braun turbo mixer (Braun, Kronberg, Germany). This procedure was also used for the preparation of pooled samples from individual samples delivered to the laboratory. Aliquots were then further homogenized in high-purity lab water (one part sample, 5 parts MilliQ-water; MilliQ, Millipore Corp.) using an Ultra-Turrax homogenizer. From this homogenate aliquots of $1 \mathrm{ml}$ were taken to analysis and for replicates as well as for matrix spikes.

The extraction method was based on ion pairing as described firstly by Ylinen et al. (1985) and further elaborated by Hansen et al. (2001) An aliquot of $1 \mathrm{~mL}$ of the homogenate was transferred to a polypropylene (PP) tube, mixed with $2 \mathrm{~mL}$ of $0.25 \mathrm{M}$ sodium carbonate buffer, and $1 \mathrm{~mL}$ of $0.5 \mathrm{M}$ tetrabutylammonium solution (TBA, adjusted with $\mathrm{NaOH}$ to $\mathrm{pH} 10$ ). The resulting mixture was vortex mixed for 20 seconds. $5 \mathrm{~mL}$ methyl tertiary butyl ether (MTBE) was added and the tube gently turned for 20 minutes. The MTBE was quantitatively transferred to a second PP-tube and another 5 $\mathrm{mL}$ MTBE portion added to the first tube and the procedure repeated. The combined MTBE extract was then gently evaporated until dryness using dry nitrogen (5.0 quality) 
and exactly $500 \mu \mathrm{L}$ methanol added. All extracts were finally filtered through a $0.46 \mu \mathrm{m}$ PP-filter prior to subsequent LC/MS determination.

\subsubsection{Quantification of abiota samples}

An Agilent high performance liquid chromatography system (HPLC, 1100 series, Agilent, Palo Alto, CA) in combination with a time-of-flight high resolution mass spectrometer (LC-TOF: Waters-Micromass, Manchester, UK) was used for quantification.

For analysis, $20 \mu \mathrm{l}$ sample extract in methanol/water $(1: 1, \mathrm{v}: \mathrm{v}, 2 \mathrm{mM}$ ammonium acetate) were injected. An ACE $\mathrm{C}_{18}$ reversed phase HPLC column (ACT, Aberdeen, $\mathrm{UK} ; 150 \times 2.1 \mathrm{~mm}, 3 \mu \mathrm{m}$ particle size) was used for PFAS separation in abiotic samples.

For HPLC separation the following parameters were chosen:

Flow rate of the mobile phase: $200 \mu \mathrm{l} / \mathrm{min}$;

Buffer: $2 \mathrm{mM}$ ammonium acetate $\left(\mathrm{NH}_{4} \mathrm{OAC}\right)$ in both methanol (A) and water (B).

Gradient of the mobile phase: $0-1 \mathrm{~min} 50 \% \mathrm{~A}$; $1-6$ min linear increase to $85 \% \mathrm{~A}, 6$ 12 min isocratic $85 \% \mathrm{~A}, 12-13$ min linear change to $99 \% \mathrm{~A}, 13-20 \mathrm{~min}$ isocratic $99 \%$ A. Equilibration time 9 min.

The compounds of interest are transferred into the TOF high-resolution mass spectrometer. PFAS were quantified with electrospray ionisation (ESI) in negative ion mode (cone voltage $-35 \mathrm{~V}$; cone gass $10 \mathrm{l} / \mathrm{hr}$; desolv. gas $400 \mathrm{l} / \mathrm{hr}$; nebulizer max). Full scan mass detection in the range of $\mathrm{m} / \mathrm{z} 200-720$.

The following masses (Table 5) were used for PFAS quantification in abiotic samples collected from Nordic environments (water, sediment and sludge):

Table 5: Quantification masses $(\mathrm{m} / \mathrm{z})$ for the determination of selected PFAS in abiotic samples. Mass tolerance was typically 0.1 mass units.

\begin{tabular}{|l|l|l|l|l|l|l|l|l|l|}
\hline Comp. & PFOSA & PFOS & PFHxS & PFBS & PFNA & PFOA & PFHxA & RSTD & ISTD \\
\hline $\mathbf{m} / \mathbf{z}$ & 498.0 & 499.0 & 399.0 & 299.0 & 419.0 & 369.0 & 269.0 & 227.0 & 281.0 \\
\hline
\end{tabular}

Please note, the selected analytes differ between biota and abiotic samples (e.g., PFHpA, PFDcS was not analysed in abiota whereas PFBS was only analysed in abiota).

Representative mass traces for LC-TOF and LC-MS-MS quantification in environmental samples (landfill effluent and grey seal liver) are presented in figure 2 (a and $b$ ). 
A:

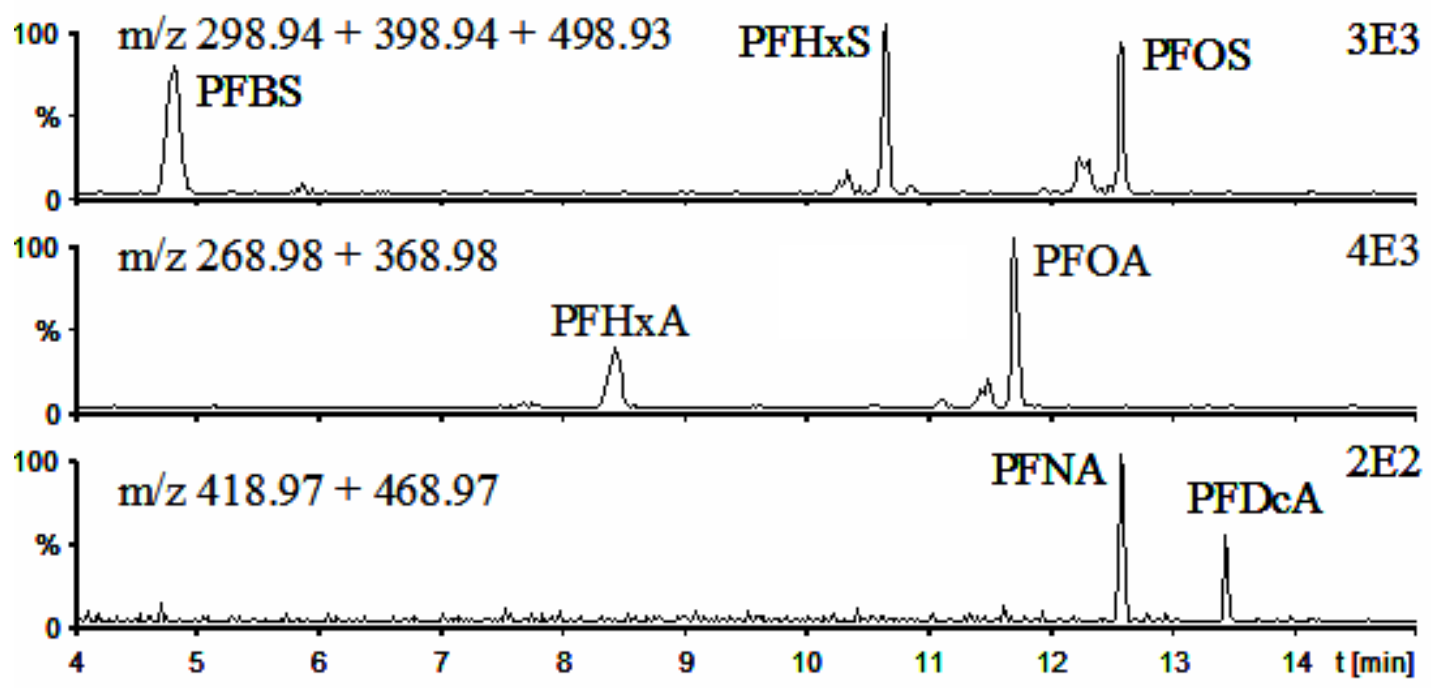

B:

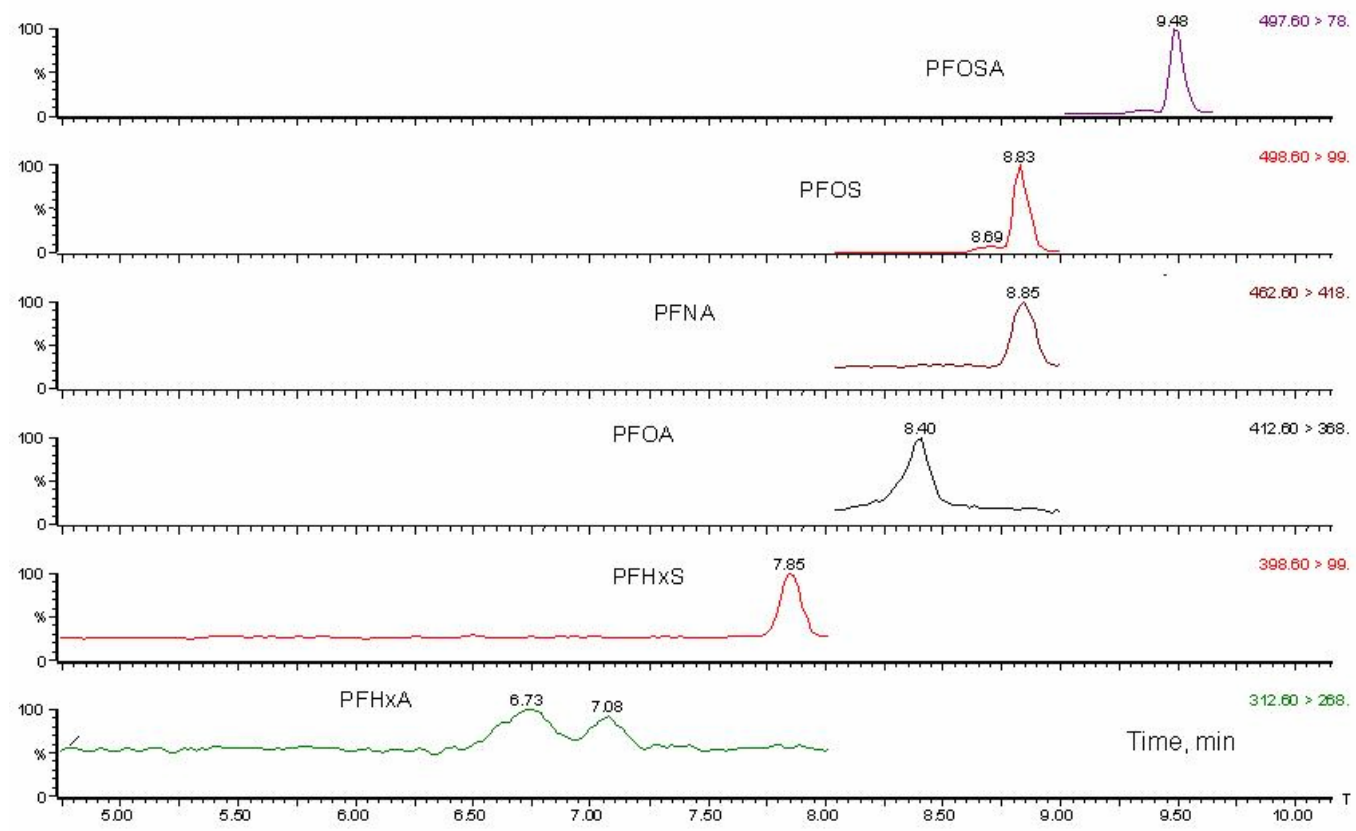

Figure 2: A.) Typical LC/MS-TOF mass traces for a landfill effluent sample.

B.) Typical LC/MS-MS chromatogram for a grey seal sample

Due to the different physico-chemical properties of the target compounds, especially for ionic compounds (sulfonates and acids) in sewage sludge, the method developed for PFOSA in sewage sludge is still considered as semi-quantitative but evaluated as sufficient for the here presented screening. 


\subsubsection{Quantification of biota samples}

Identification and quantification was done by retention time using authentic reference compounds and selected reaction monitoring (Figure 2b: SRM-MS/MS, Micromass Quattro II, Altrincham, U.K.) with argon as a reaction gas and monitoring the transitions listed in table 6 . The MS/MS instrumental conditions were identical to those described by Giesy and Kannan (2001). The detection limit was calculated from a low level spiked and extracted sample and was considered to be equal to three times the area noise level in each transition in the region of the target compound.

Table 6. Monitored MS/MS transitions

\begin{tabular}{|l|l|l|l|}
\hline Analyte & Abbrev. & Precursor ion & Product ion \\
\hline Perfluorohexanoic acid & PFHxA & 313 & 269 \\
\hline Perfluoroheptanoic acid & PFHpA & 363 & 319 \\
\hline Perfluorooctanoic acid & PFOA & 413 & 369 \\
\hline Perfluorononanoic acid & PFNA & 463 & 419 \\
\hline Perfluorohexane sulfonate & PFHxS & 399 & 99 \\
\hline Perfluorooctane sulfonate & PFOS & 499 & 99 \\
\hline Perfluorodecane sulfonate & PFDS & 599 & 99 \\
\hline Perfluorooctane sulfonamide & PFOSA & 498 & 78 \\
\hline
\end{tabular}

The LC system consisted of a C18 - column $(2.1 \mathrm{~mm}$ x $50 \mathrm{~mm}$ x $5 \mu \mathrm{m}$, Hypurity C18, ThermoHypersil, U.K.) with methanol/water as the eluent and $10 \mathrm{mM}$ ammonium acetate as modifier. The eluent was delivered at a flow of $0.2 \mathrm{ml} / \mathrm{min}$ by a Waters Alliance 2690 pump (Waters Corp., Milford, MA. U.S.A.) with a gradient program starting at $40 \%$ methanol increased to $95 \%$ at $5 \mathrm{~min}$, kept for $15 \mathrm{~min}$ and then returned to $40 \%$ at $20 \mathrm{~min}$. Total run time was $35 \mathrm{~min}$., including time for conditioning of the column. All calculations were done using multilevel calibration curves of respective matrix extracts spiked with external standard mixtures and using corrections for recovery of the different analytes. Generally, at least two spike levels were included for each new matrix and/or batch. Method blanks consisting of extracted MilliQ-water (Millipore, Billerica, MA, USA) were included with each batch and one field blank consisting of triolein was also analysed.

\subsection{Quality control and method comparison}

Adequate quality control measures and documentation were introduced covering the entire analytical chain: sampling procedures, storage, transport, sample preparation and, ultimately analysis and quantification. For an appropriate sampling procedure with the aim to minimise contamination risk and document possible artefacts during sampling and transport, sampling protocol was developed in close co-operation between the analytical laboratories and the screening project's steerning project. 


\subsubsection{Sampling protocol}

Annex 1: Sampling protocol for sea-/river-/lake-water samples

\begin{tabular}{|l|l}
\hline Sample name: & Sample material:
\end{tabular}

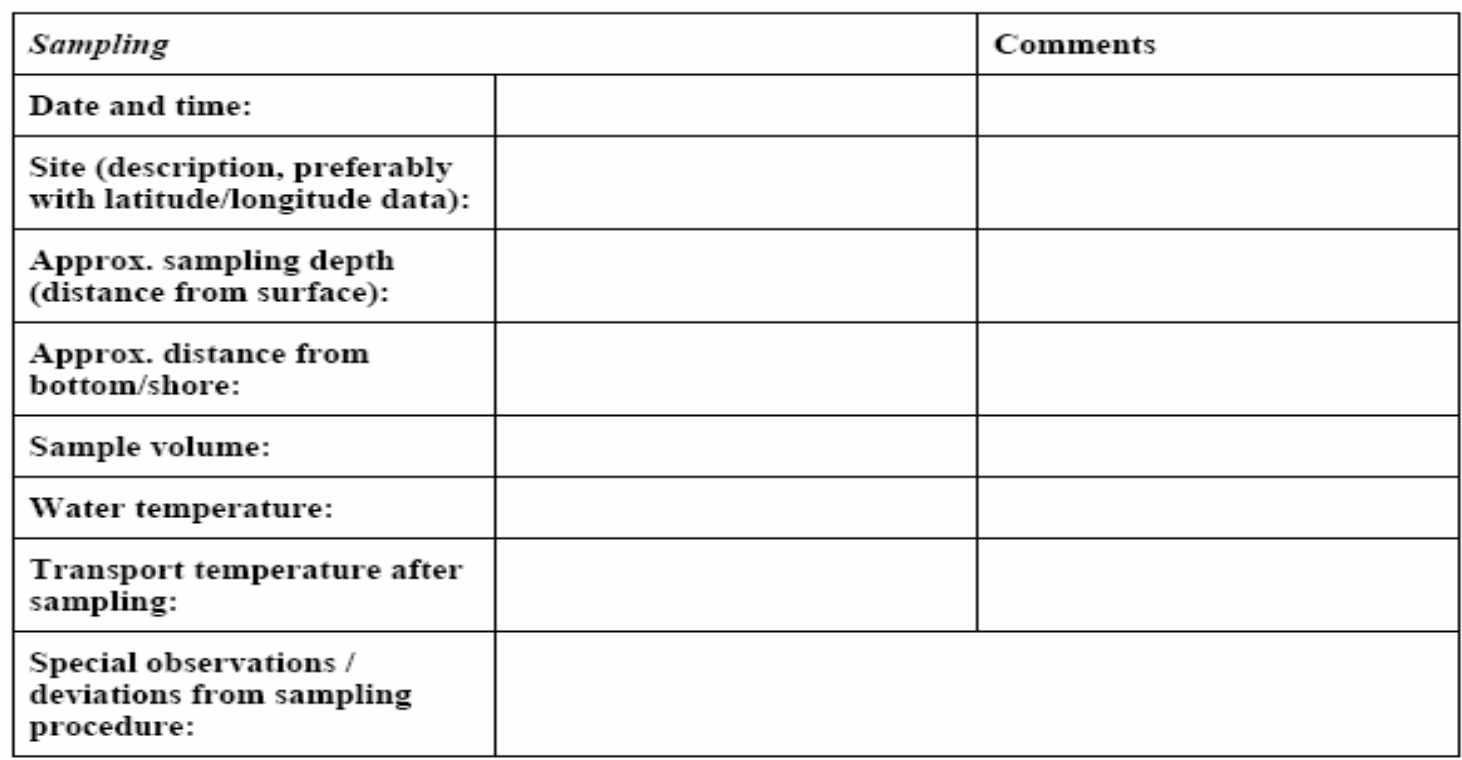

\begin{tabular}{|l|l|l|}
\hline Storage & & Comments \\
\hline Storage time: & & \\
\hline Storage temperature: & & \\
\hline Special observations: & & \\
\hline
\end{tabular}

\begin{tabular}{|l|l|l|}
\hline Shipping & & Comments \\
\hline Date sample sent: & & \\
\hline Shipping temperature: & & \\
\hline Date sample received*: & & \\
\hline Condition upon receipt*: & & \\
\hline Special observations*: & & \\
\hline * To be filled in by NILU
\end{tabular}

Figure 3: Sampling protocol sheet for the collection of sea-, river and lake water samples for the Nordic PFAS screening project.

The sampling protocol (Appendix 2, sampling manual) was developed with the overall aim to address two major needs:

1.) Guidance for the personnel, responsible for sampling to avoid contamination.

2.) Ensure a complete documentation of the sampling procedure, quality of the sample and environmental circumstances during the sampling period.

Sampling protocols for seven major sample types were developed and distributed to the participating institutions. A typical sampling sheet is presented in figure 3, the 
complete selection can be found in appendix 2 (sampling manual incl. supplementary information).

\subsubsection{Limit of detection/ limit of quantification}

Limit of detection (LOD) and limit of quantification (LOQ) are considered as two priority parameters, describing the quality of a quantitative analytical method. According to IUPAC (McNaught and Wilkinson 1997, Thomsen et al. 2003), the LOD, expressed as the concentration, $c \mathrm{~L}$, or the quantity, $q \mathrm{~L}$, is derived from the smallest measure, $x \mathrm{~L}$, that can be detected with reasonable certainty for a given analytical procedure. The value of $x \mathrm{~L}$ is given by the equation: $\mathrm{xL}=x \mathrm{bi}-+k s \mathrm{bi}$

where $x \mathrm{bi}-$ is the mean of the blank measures, sbi is the standard deviation of the blank measures, and $k$ is a numerical factor chosen according to the confidence level desired.

For abiotic and biotic samples $k=3$ ( $3 \mathrm{x}$ signal/noise) was chosen for the present screening study.

According to guidelines developed by the "US great Lakes monitoring programme", the limit of quantification is defined as the lowest concentration of an analyte that produces a signal/response that is sufficiently greater than the signal/response of lab reagent blanks to enable reliable detection (and thus quantification) during routine laboratory operating conditions. The analyte response at the limit of quantification (LOQ) should be at least 5 times the response compared to the blank response (www.epa.gov/glnpo/monitoring/data_proj/glenda/codes/r_lim_tp.pdf).

During the present screening exercise, for PFAS analysis in abiotic samples the LOQ was set $5 \mathrm{x}$ compound level in the highest field blank for the respective sample type. For PFAS determination in biota, the LOQ was defined as $3 \mathrm{x}$ compound level in the highest field blank for the respective sample type.

LOD and LOQ determination was performed in accordance to the guidelines given in the above described documents.

\subsubsection{Laboratory and field blanks}

Laboratory and field blank analysis was an essential part of the quality control program. For all sample types relatively low laboratory and field blank levels have been determined except for PFOA where elevated concentration levels were found indicating possible contamination during transport and sample preparation (table 7 and 8).

Table 7: Laboratory and field blank determination for aqueous samples

\begin{tabular}{|c|c|c|c|c|c|c|c|c|c|c|}
\hline \multirow[t]{2}{*}{ Sample ID } & \multirow[t]{2}{*}{ Sample matrix } & \multirow[t]{2}{*}{ Blank } & \multicolumn{8}{|c|}{ Total concentration in water samples (ng/l, water phase) } \\
\hline & & & \begin{tabular}{|r|} 
PFOSA \\
\end{tabular} & PFBS & PFHxS & PFOS & PFHxA & PFOA & PFNA & Recovery (\%) \\
\hline LAWABL01 & Milli $Q$ water & Lab-blank (Water) & 0.00 & 0.00 & 0.00 & 0.03 & 0.00 & 0.26 & 0.00 & 73 \\
\hline LAWABL02 & Milli $Q$ water & Lab-blank (Water) & 0.00 & 0.00 & 0.00 & 0.04 & 0.00 & 0.27 & 0.00 & 76 \\
\hline WABLFIN01 & Ion free water & water (Finland) & 0.00 & 0.00 & 0.00 & 0.04 & 0.00 & 0.24 & 0.00 & 62 \\
\hline \begin{tabular}{|l} 
WABLNOR01 \\
\end{tabular} & lon-exchange water & Water (Norway) & 0.00 & 0.00 & 0.00 & 0.01 & 0.00 & 0.25 & 0.00 & 67 \\
\hline WABLDAN01 & Milli Q water & Water (Danmark) & 0.00 & 0.00 & 0.00 & 0.04 & 0.00 & 0.44 & 0.00 & 65 \\
\hline WABLICE01 & & Water (Iceland) & 0.00 & 0.00 & 0.00 & 0.05 & 0.00 & 0.59 & 0.00 & 85 \\
\hline WABLFAR01 & & Water (Faroe Iceland) & 0.00 & 0.00 & 0.00 & 0.02 & 0.00 & 0.25 & 0.00 & 73 \\
\hline \multicolumn{3}{|c|}{ LOD water (instrumental signal-to-noise 3:1) } & 0.01 & 0.03 & 0.01 & 0.02 & 0.06 & 0.06 & 0.05 & \\
\hline \multicolumn{3}{|c|}{ LOQ water ( 5 times highest field blank) } & 0.05 & 0.03 & 0.07 & 0.25 & 0.15 & 3.00 & 0.10 & \\
\hline
\end{tabular}


The recovery rates for the abiota blank samples (table 7 and 8) was calculated for the internal standard (ISTD: 7H-PFHpA) against the recovery standard (RSTD: 3,5bis(trifluoromethyl)phenyl acetic acid $=100 \%$ ) assuming representative behaviour of the ISTD compared to the unknown PFAS target analytes (see table 14).

The method limit of quantification (LOQ) was set as $5 \mathrm{x}$ highest field blank levels determined (table 8) or, if no blank levels were present, as $5 \mathrm{x}$ background noise in the chromatogram.

For biota standard spiked extracted matrix experiments have been performed to determine the respective recovery rates for all target analytes.

The detection limit was calculated from a low level spiked and extracted sample and was considered to be equal to three times the area noise level in each transition in the region of the target compound. The concentrations of target analytes were in the following range: low level spiked $=3-8 \mathrm{ng} / \mathrm{g}$; high level spiked $=30-80 \mathrm{ng} / \mathrm{g}$.

Table 8: Laboratory and field blank determination for sediment and sewage sludge samples [ng/g ww].

\begin{tabular}{|c|c|c|c|c|c|c|c|c|c|}
\hline Sample ID & Sample matrix & Blank & PFOSA & $\mathrm{PFHxS}$ & PFOS & PFHxA & PFOA & PFNA & $\begin{array}{r}\text { Recovery } \\
(\%)\end{array}$ \\
\hline LASEBLFAR01 & Sea-sand & Sediment/sludge (Faroe Islands) & 0 & 0 & 0 & 0 & 16 & 0 & 66 \\
\hline \begin{tabular}{|l} 
LASEBLFAR02 \\
\end{tabular} & Sea-sand & Sediment/sludge (Faroe Islands) & 0 & 0 & 0 & 0 & 15 & 0 & 78 \\
\hline SEBLNOR01 & Silica + water & Sediment (Norway) & 3 & 0 & 5 & 0 & 59 & 0 & 90 \\
\hline SEBLICE01 & Silica & Sediment (Iceland) & 4 & 0 & 10 & 0 & 67 & 0 & 53 \\
\hline SSBLSWE01 & Silica + tap water & Sludge (Sweden) & 0 & 2 & 7 & 0 & 60 & 0 & 77 \\
\hline \multicolumn{3}{|c|}{ LOD (instrumental signal-to-noise 3:1) } & 1 & 0 & 2 & 5 & 6 & 5 & \\
\hline \multicolumn{3}{|c|}{ LOQ (5 times highest field blank) } & 18 & 7 & 50 & 10 & 200 & 10 & \\
\hline
\end{tabular}

- = not analysed.

The Finnish participants sent one field blank sample of triolein (standardised lipid: $\mathrm{C}_{57} \mathrm{H}_{104} \mathrm{O}_{6}$; CAS-nr. 122-32-7) to ITM. No target analytes were detected in this sample. The field blank was analysed in parallel with the Finnish pike samples with high recovery $(50-80 \%)$ for all target analytes.

Analytical method blanks (MilliQ water) have accompanied each series and instrument blanks $(\mathrm{MeOH})$ were included with each instrument series. Limit of detection levels are calculated as instrument detection limit at 100\% recovery (table 9). The method LOD describes the lowest detection range depending on sample matrix (see 3.4.2).

For the PFAS analysis in biota, the recovery rates were found to be highly matrix dependent. The recovery ranges are listed in Table 10. Recovery is corrected for by quantifying each sample using a spiked and extracted sample from each series and matrix type. 
Table 9: Limit of detection (instrument and method) for the target PFAS compounds in biota $[\mathrm{ng} / \mathrm{g}]$.

\begin{tabular}{|l|l|l|l|l|l|l|l|l|}
\hline Compound & PFHxA & PFHpA & PFHxS & PFOA & PFNA & PFOS & PFOSA & PFDS \\
\hline LOD type & Instrument Instrument & Instrument & Instrument & Instrument & Instrument & Instrument & Instrument \\
& LOD & LOD & LOD & LOD & LOD & LOD & LOD & LOD \\
\hline LOD [ng/g ww] & $\mathbf{0 . 5}$ & $\mathbf{0 . 3}$ & $\mathbf{0 . 4}$ & $\mathbf{0 . 4}$ & $\mathbf{0 . 4}$ & $\mathbf{0 . 5}$ & $\mathbf{0 . 1}$ & $\mathbf{1 . 4}$ \\
\hline LOD Type & Metod & Metod & Metod & Metod & Metod & Metod & Metod & Metod \\
& LOD & LOD & LOD & LOD & LOD & LOD & LOD & LOD \\
\hline LOD [ng/g ww] & $\mathbf{0 . 5 - 1 . 3}$ & $\mathbf{0 . 3 - 0 . 4}$ & $\mathbf{0 . 4 - 1 . 4}$ & $\mathbf{0 . 6 - 1}$ & $\mathbf{0 . 6 - 1}$ & $\mathbf{0 . 6 - 1}$ & $\mathbf{0 . 8}$ & $\mathbf{1 . 4 - 1 . 8}$ \\
\hline
\end{tabular}

Table 10: Recovery ranges for PFAS in biota [\%]

\begin{tabular}{|l|l|l|l|l|l|l|l|}
\hline PFHxA & PFHpA & PFHxS & PFOA & PFNA & PFOS & PFOSA & PFDS \\
\hline $67-105$ & $72-111$ & $70-90$ & $40-72$ & $43-82$ & $55-78$ & $26-36$ & $22-78$ \\
\hline
\end{tabular}

Repeated injection of selected biota samples revealed the low variation in the quantification method for PFAS quantification in biota using LC-MS/MS techniques (table 11).

Table 11: Repeated PFOS quantification for Swedish and Finnish biota samples

\begin{tabular}{|l|l|l|}
\hline Sample & Day 1 & Day 2 \\
\hline COSWE06 & 9.1 & 10.9 \\
COSWE07 & 8.1 & 9.0 \\
COSWE08 & 8.7 & 9.0 \\
COSWE09 & 20 & 24.5 \\
COSWE10 & 6.4 & 8.4 \\
COSWE06 & 6.4 & 11.0 \\
\hline & & \\
\hline PIFIN01 & 594 & 551 \\
PIFIN02 & 220 & 204 \\
PIFIN03 & 227 & 211 \\
PIFIN04 & 258 & 240 \\
PIFIN05 & 284 & 263 \\
PIFIN06 & 273 & 253 \\
PIFIN07 & 530 & 492 \\
\hline
\end{tabular}

\subsubsection{Performance tests (parallel samples)}

As a part of an accompanying quality control programme abiotic samples (seawater, precipitation (rainwater), landfill effluent, sewage effluent, sediment and sewage sludge samples) as well as biota (long-rough dab, Arctic char and perch) have been collected in parallel to document the representativeness of sampling methods as well as analytical method variability and robustness of sample preparation (table 3). From 6 countries 6 
different sample types (16 samples) were collected in parallel (2- 5 parallel samples respectively). The complete dataset can be found in appendix 3 (concentration lists).

Depending on sample type, sample numbers and absolute concentration the relative deviation varied between $3 \%$ and $22 \%$ for the method used for abiotic compounds. The variability in the parallel sampling test documents that the method repeatability is sufficient for the present screening exercise. In addition, sample types and amounts showed to be sufficiently representative for the screening exercise.

\subsubsection{Laboratory intercomparison}

For a first method intercomparison and as an integrated part of the quality control program, a standard solution (in methanol) was prepared for parallel quantification of PFAS compounds using the respective trace-analytical methods developed by the two participating Nordic laboratories. The results are summarised in table 13.

Table 12: Method intercomparison between the NILU and the ITM method used for PFAS determination and quantification (see method description).

Concentration of the standard solution in methanol $=$ Theoretical values

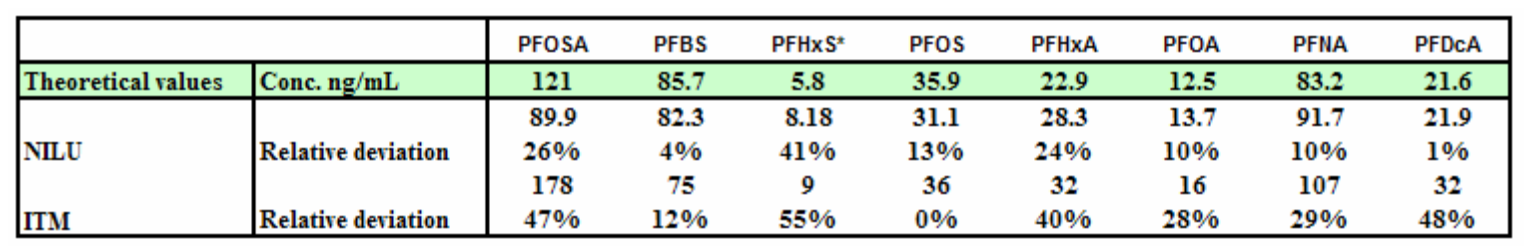

*please note, PFHxS is present as contamination in the PFOS standard mixture. Therefore, the theoretical value for PFHxS is probably underestimated.

For both methods deviations from the expected concentration value up to $55 \%$ have been found (table 12) demonstrating the results of the analytical methods used in this studies are considered acceptable compared with well-established and fully evaluated monitoring methods. However, a more comprehensive method comparison is needed to fully evaluate the analytical methods. The overall results of this first method intercomparison showed a good quality of the analytical and quantification methods sufficient for the here performed screening exercise with regard to accuracy and comparability of the method.

Thus, for future quality control and assurance tests, sample preparation methods as well as matrix related method intercomparison will be considered as additional necessary step in direction of a fully evaluated and quality assured trace analytical method. 
Table 13. Differences between the NILU and ITM PFAS quantification method.

\begin{tabular}{|l|l|l|}
\hline Topic & Laboratory \\
\hline Standard calibration & $\begin{array}{l}\text { Internal and external } \\
\text { quantification standard } \\
\text { calibration }\end{array}$ & $\begin{array}{l}\text { External matrix spike } \\
\text { standard for calibration }\end{array}$ \\
\hline Recovery & Internal recovery standard & Spiked extracted matrix \\
\hline Instrumentation & LC-TOF (ESI) & LC-quadrupole MS (ESI ${ }^{-}$) \\
\hline $\begin{array}{l}\text { Identification/ } \\
\text { quantification }\end{array}$ & $\begin{array}{l}\text { High resolution single m/z } \\
\text { quantification }\end{array}$ & SRM-MS/MS transition \\
\hline
\end{tabular}

As already outlined before, both methods are developed following different concepts with regard to sample preparation, analysis and quantification. The major differences are identified for the final LC/MS analysis and quantification (Table 13).

\subsubsection{Data handling and comparison}

Compound- specific comparison of PFAS related residues in the various sample types is performed using median values instead of arithmetic mean since concentration distribution is not assumed to be normal distributed. 


\section{Results}

The here presented data sets represent the first attempt to evaluate the distribution of PFAS related compounds in the Nordic environment. Institutions from 6 Nordic nations participated in the here presented screening exercise. A comprehensive selection of 23 different sample types representing abiotic and biotic environments were selected for the study (table 2).

Table 14A: Nomenclature for the selected abiotic samples within the Nordic PFAS Screening.

\begin{tabular}{|l|l|l|l|l|}
\hline Sample type & Abbreviation & Country & Abbreviation & Sample Number \\
\hline Sediment & SD & Finland & FIN & $10-12$ \\
\hline Sediment & SD & Faroe islands & FAR & $5-7$ \\
\hline Sediment & SD & Norway & NOR & $12-14$ \\
\hline Sediment & SD & Sweden & SWE & $4-6$ \\
\hline Sediment & SD & Iceland & ICE & $2(a-e)$ \\
\hline Sewage sludge & SS & Finland & FIN & $13,14(a-c)-16$ \\
\hline Sewage sludge & SS & Norway & NOR & $15-16$ \\
\hline Sewage sludge & SS & Denmark & DAN & $4-6$ \\
\hline Sewage sludge & SS & Iceland & ICE & $3(a-b)-4(a-b)$ \\
\hline Sewage Sludge & SS & Sweden & SWE & $7-9$ \\
\hline Sewage sludge & SS & Faroe islands & FAR & 8 \\
\hline Seawater & SW & & & $1-4$ \\
\hline Seawater & SW & Denmark & DAN & $1-2(a-b)-3$ \\
\hline Seawater & SW & Iceland & ICE & $1(a-d)$ \\
\hline Seawater & SW & Faroe islands & FAR & $1-3$ \\
\hline Rain water & RW & Finland & FIN & $5-6$ \\
\hline Rain water & RW & Sweden & SWE & $1(a-b)-3$ \\
\hline Lake water & LW & Norway & NOR & $1-4(a-b)$ \\
\hline Sewage effluent & SE & Finland & FIN & $8-9(a-b)$ \\
\hline Sewage effluent & SE & Norway & NOR & $10-11(a-b)$ \\
\hline Sewage effluent & SE & Faroe islands & FAR & 4 \\
\hline Landfill effluent & LE & FIN & $7(a-c)$ \\
\hline Landfill effluent & LE & Norway & NOR & $5(a-b)-9$ \\
\hline
\end{tabular}


Sampling, sample handling, transport, sample preparation and quantification were performed along a detailed quality control program including sampling manual and standardised laboratory procedures ensuring the best possible data quality for the analysed Nordic samples. The nomenclature, chosen for the samples selected within the here presented Nordic screening exercise for perfluorinated organic contaminants (PFAS) is listed in table 14A and B.

According to the above given table 14A, the sample number is composed by the abbreviations of sample type, countries name and the sample number. Thus, the $4^{\text {th }}$ seawater sample from Finland is named SWFIN04. Please note parallel samples are distinguished with letters (a-e).

Table 14B: Nomenclature for the selected biotic samples within the Nordic PFAS screening.

\begin{tabular}{|l|l|l|l|l|}
\hline Sample type & Abbreviation & Country & Abbreviation & $\begin{array}{l}\text { Sample } \\
\text { Number }\end{array}$ \\
\hline Pike & PI & Finland & FIN & $1-8$ \\
\hline Pike & PI & Norway & NOR & 3 \\
\hline Perch & PE & Sweden & SWE & $1-3(\mathrm{a}-\mathrm{b}, 4$ \\
\hline Perch & PE & Norway & NOR & 4 \\
\hline Burbot & BU & Norway & NOR & 1 \\
\hline Atlantic cod & CO & Sweden & SWE & $5-12$ \\
\hline Atlantic cod & CO & Faroe islands & FAR & 5 \\
\hline Grey seal & GS & Sweden & SWE & $14-16$ \\
\hline Harbour seal & HS & Denmark & DAN & $7-11$ \\
\hline Trout & TR & Norway & NOR & 2 \\
\hline Flounder & FL & Denmark & DAN & $1-4$ \\
\hline Eelpout & EP & Denmark & DAN & 5 \\
\hline Herring & HE & Denmark & DAN & 6 \\
\hline Long-rough dab & LD & Iceland & ICE & $1(\mathrm{a}-\mathrm{c})-2$ \\
\hline Shorthorn sculpin & SC & Iceland & ICE & 3 \\
\hline Shorthorn sculpin & SC & Faroe Islands & FAR & $1-2$ \\
\hline Dab & DA & Iceland & ICE & 4 \\
\hline Dab & DA & Faroe islands & FAR & $3-4$ \\
\hline Minke whale & MW & Iceland & ICE & $5-9$ \\
\hline Arctic char & FC & Faroe islands & FAR & $6(\mathrm{a}-\mathrm{b})-7$ \\
\hline Pilot whale & Faroe islands & FAR & $8-11$ \\
\hline Fulmar & Faroe islands & FAR & $12-13$ \\
\hline
\end{tabular}

According to the above given table 14B, the sample number is composed by the abbreviations of sample type, countries name and the sample number. Thus, the $4^{\text {th }}$ pike sample from Finland is named PIFIN04. 
Blank samples are additionally abbreviated with "BL". Thus, the first field blank for Swedish sewage sludge is named SSBLSWE01 (see table 8).

\subsection{Levels and distribution}

A comprehensive sample set consisting of 119 environmental samples:

- 11 seawater samples from 4 Nordic countries

- 5 rainwater samples from 2 Nordic countries

- 6 landfill effluent samples from 2 Nordic countries

- 5 sewage effluent samples from 3 countries

- 15 sewage sludge samples from 6 Nordic countries

- 13 sediment samples from 5 Nordic countries

- 4 Lake water samples from 1 Nordic country

- 23 marine fish samples from 5 Nordic countries

- 18 freshwater fish samples from 4 Nordic countries

- 17 marine mammal samples from 4 Nordic countries

- 2 pooled seabird egg samples from 1 Nordic country.

represents the basis for the here presented first investigation on the fate and distribution of PFAS related residues in the Nordic environment (table 2).

Although a large number of samples is represented, the large variety of sample types collected in each country and the small number of individual samples representing the respective sample type restrict the assessment of general trends and spatial distribution. The differences between sampling locations and sample types within a Nordic country may be as large as between the respective countries. These variations are not considered in the here presented screening study. Thus, the results presented herein, should only be considered and discussed as indications and hints for further in-depth scientific studies.

\subsubsection{Abiotic samples}

The abiotic subset of samples consisted of 59 samples ranging from seawater to sewage sludge and sediments (table 2). For a better comparison the abiotic sample set is divided into two sub-groups: abiotic solid samples and aqueous samples.

\section{Solid abiotic samples}

The highest levels in solid abiotic sample material for PFAS related residues were found for sewage sludge samples (SSSWE09, PFOS = $2644 \mathrm{pg} / \mathrm{g} \mathrm{ww}$ ). Considerable concentration differences were found for the various sample types (figure 4). 


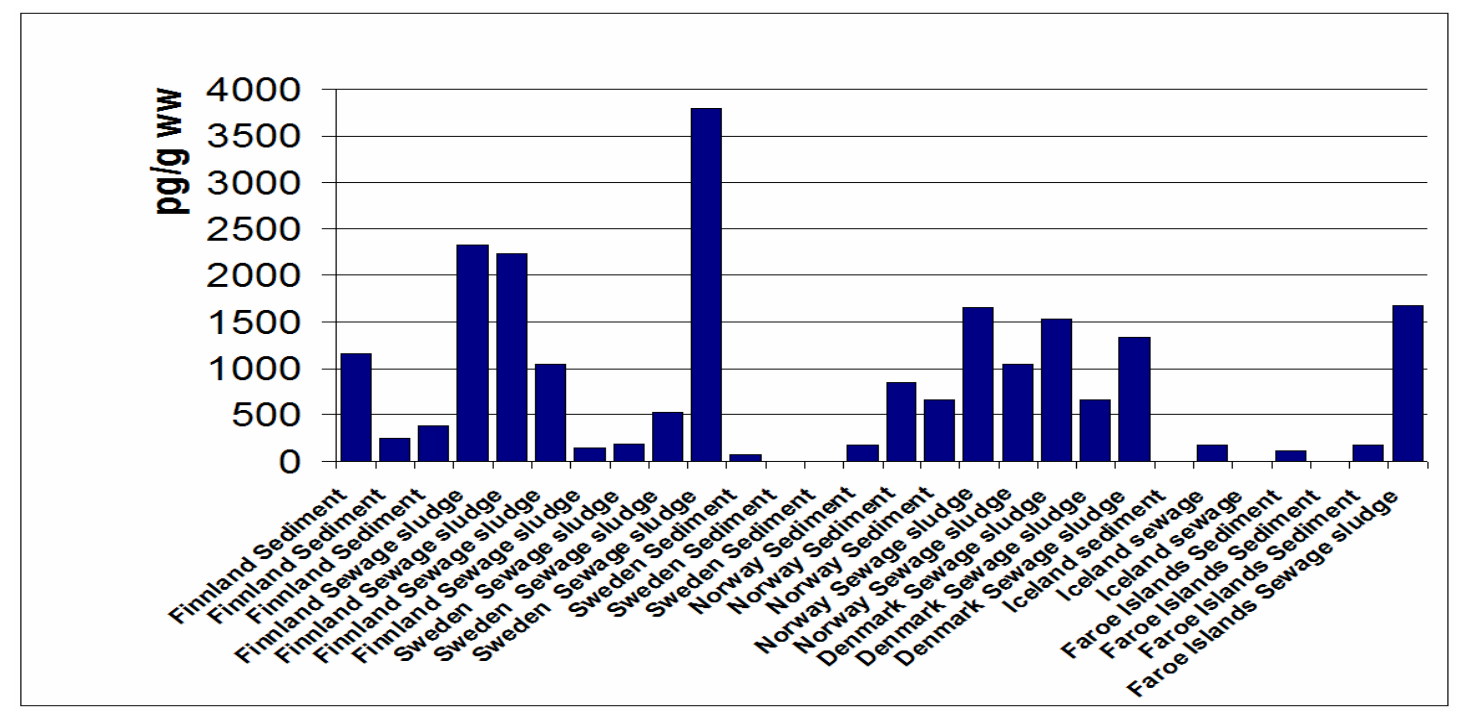

Figure 4: SUM PFAS concentration for solid abiotic samples: Sediment and sewage sludge from Nordic countries.

$$
\text { SUM PFAS }=\text { PFOSA }+ \text { PFHxS }+ \text { PFOS }+ \text { PFHxA }+ \text { PFOA }+ \text { PFNA. }
$$

In general, sewage sludge samples have higher PFAS content compared to sediment samples. However, indications for surprisingly high variability in sewage sludge are found. The lowest contaminated sewage sample was from Finland (SSFIN16: $150 \mathrm{pg} / \mathrm{g}$ ww) and the highest from Sweden (SSSWE09: $3793 \mathrm{pg} / \mathrm{g} \mathrm{ww}$ ). Sum concentrations for sewage sludge in Finland vary between 150 - 2521 pg/g ww, Sweden between, 168 3793 pg/g ww, Norway between: 1048 - 1654 pg/g ww, Iceland around 234 pg/g ww and Faroe islands around $1677 \mathrm{pg} / \mathrm{g} \mathrm{ww}$. The Denmark samples are found in the range between 650 and $1500 \mathrm{pg} / \mathrm{g}$ ww. Country specific sewage sludge release pattern cannot be excluded as possible reason for these differences. However, numerous factors influence the final concentrations in sewage sample (e.g., differences in the concentrations in sewage effluents may be influenced by the amount of clean water passing through the plant). However, also the distribution patterns (figure 5) for the analysed sewage sludge samples reflect the variability of the PFAS compounds found in this specific matrix. 


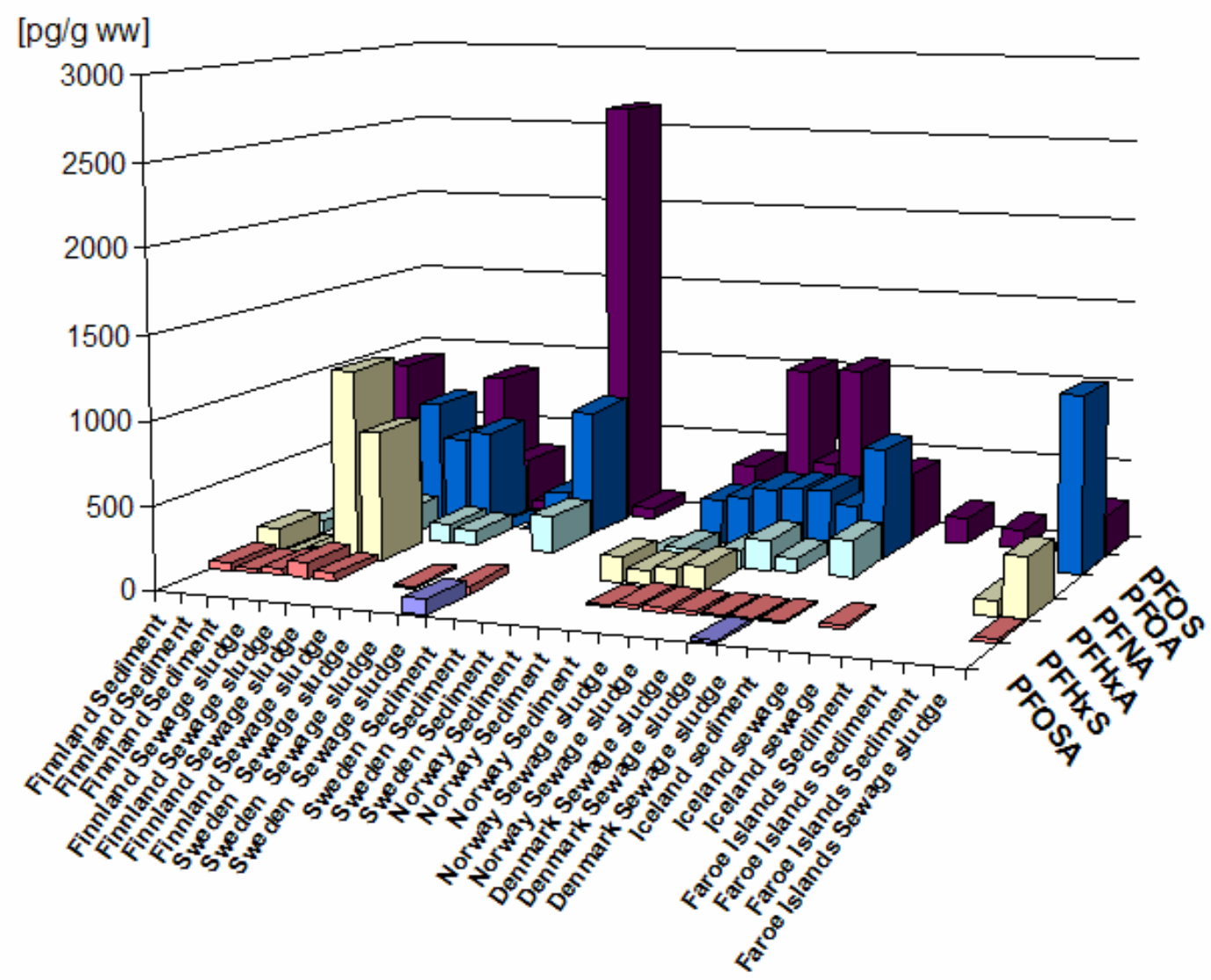

Figure 5: Compound specific levels for PFAS residues in solid abiotic samples: Sediment and sewage sludge. Concentration levels are given in $\mathrm{pg} / \mathrm{g}$ ww (for more sampling details see appendices).

PFOS and PFOA are the predominant PFAS residues in solid abiotic samples. However, in the Finnish sewage sludge samples (see appendix 3: SSFIN13 and SSFIN14) also PFHxA is contributing significantly to the PFAS burden. No detectable PFAS residues were found in the Swedish freshwater sediment samples except for one sample were PFOS was found (SDSWE04: PFOS $=69 \mathrm{ng} / \mathrm{g} \mathrm{ww}$ ). In the only Icelandic sediment sample all PFAS were below limit of quantification (LOQ).

\section{Aqueous samples}

For the here presented screening study five different types of aqueous sample types were chosen: Seawater, lake water, rain water, sewage effluent and landfill effluent (table 2). Remarkable concentration differences were found for the different sample types (Figure 5). Highest levels were found for Norwegian landfill effluent samples $($ LFNOR06 ; SUM PFAS $=1537 \mathrm{ng} / \mathrm{L}$, LFNOR08; SUM PFAS $=1162 \mathrm{ng} / \mathrm{L}$ ). The Finnish landfill effluent samples were collected in parallel and reflect again the good repeatability of the analytical method (see chapter about quality control). Sewage effluent had considerable lower concentration levels (SUM PFAS, SENOR11 = 59 ng/L and SEFIN08 $=105 \mathrm{ng} / \mathrm{L})$. Lowest concentrations were found for lake water and seawater samples (Figure 5) and rainwater levels ranging between sewage effluent and lake water concentrations. In all aqueous samples regardless sample type PFOA represented the predominant PFAS compound (expect for the highest contaminated Landfill effluent sample LFNOR06 where PFHxA was the predominant PFAS related residue). PFOS, the most prominent PFAS residue in solid abiotic samples, is not as 
dominant in the aqueous samples. However in Finnish landfill effluent samples PFOS is found in the same concentration range as PFHxA.

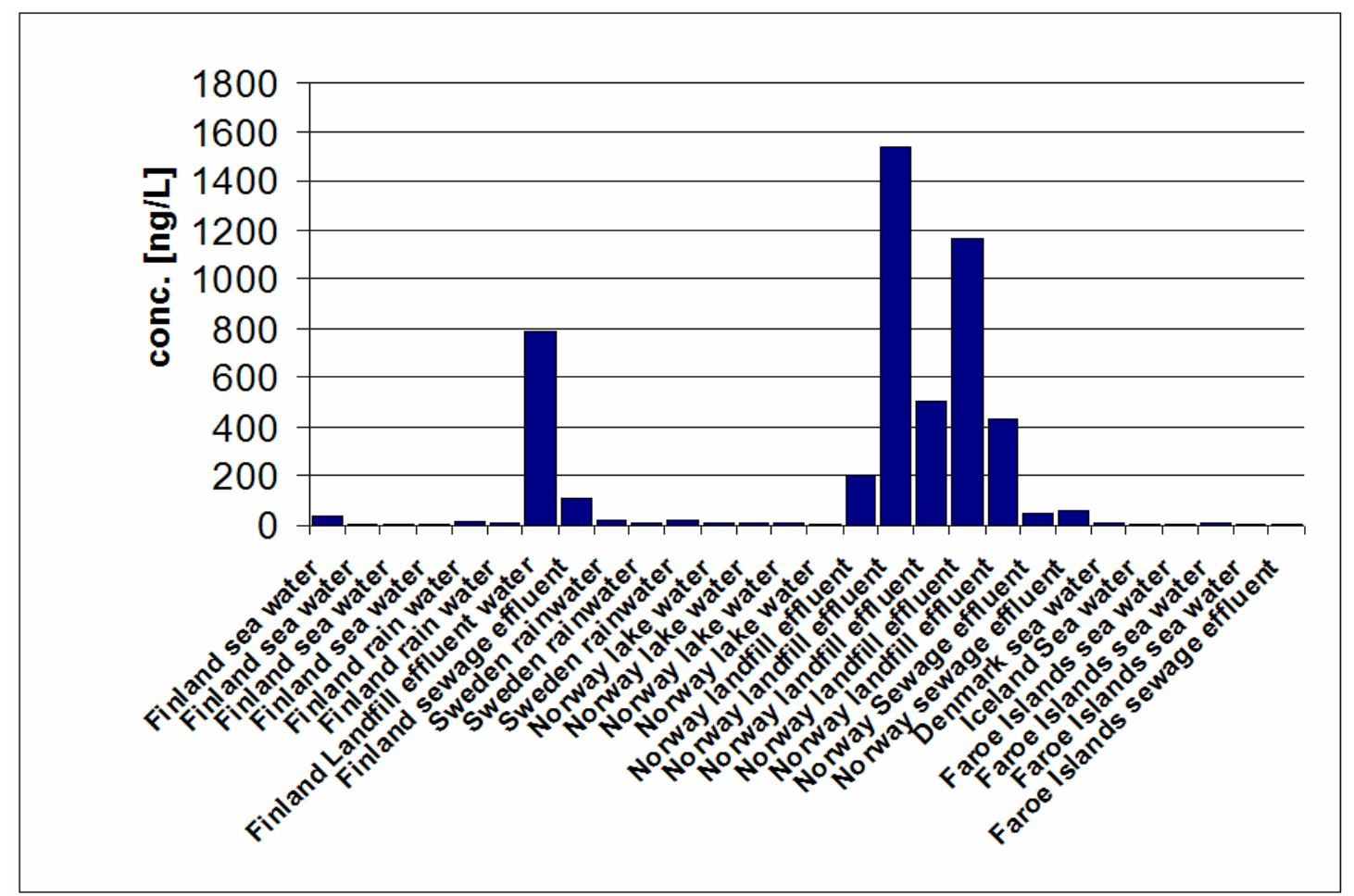

Figure 6: SUM PFAS concentration for aqueous abiotic samples: Seawater, rain water, lake water, landfill effluents and sewage effluents. Concentrations are given in SUM PFAS $=$ ng/L. SUM PFAS = PFOSA + PFBS + PFH $x$ S + PFOS + PFHxA + PFOA + PFNA.

For more information on the sample characteristics see appendices 1 and 3.

\subsubsection{Biota}

For comparison, the biota samples collected for the Nordic PFAS screening are presented as four sub-groups: Freshwater fish, marine fish, seabirds and marine mammals. A total of 60 biota samples are collected whereof 23 are marine fish samples, 18 freshwater fish, 17 marine mammals and 2 marine bird samples (table 2).

The comprehensive selection of biota samples represents various biological and environmental endpoints. Thus, differences in levels and pattern distribution are expected to be related to trophic level, food habit, habitat, age, sex etc (biological information as well as other sample characteristics are summarised in appendix 1).

\section{Freshwater fish}

In all freshwater fish (liver), PFOS is the predominant PFAS representative (figure 7) followed by PFOSA regardless trophic level except for one sample (PINOR03; PFOS = $24 \mathrm{ng} / \mathrm{g} \mathrm{ww}$, PFOSA $=60 \mathrm{ng} / \mathrm{g} \mathrm{ww}$ ) where PFOSA is the most prominent compound. Pike represents the freshwater top predators and, thus, shows the highest PFAS contamination in the analysed freshwater biota. The highest PFAS levels were found in Finnish Pike samples (PIFIN01, PFOS $=551 \mathrm{ng} / \mathrm{g} \mathrm{ww}$, PFOSA $=141 \mathrm{ng} / \mathrm{g} \mathrm{ww}$ ). PFOS and PFOSA represent in all samples more than $90 \%$ of the PFAS burden. 
Although the Swedish perch samples represent a lower trophic level as pike, the PFOS levels are not significantly lower than found for Pike. However, the PFOSA contribution is significantly minor compared to pike pointing towards food chain specific uptake or differences in transformation processes (Figure 7).

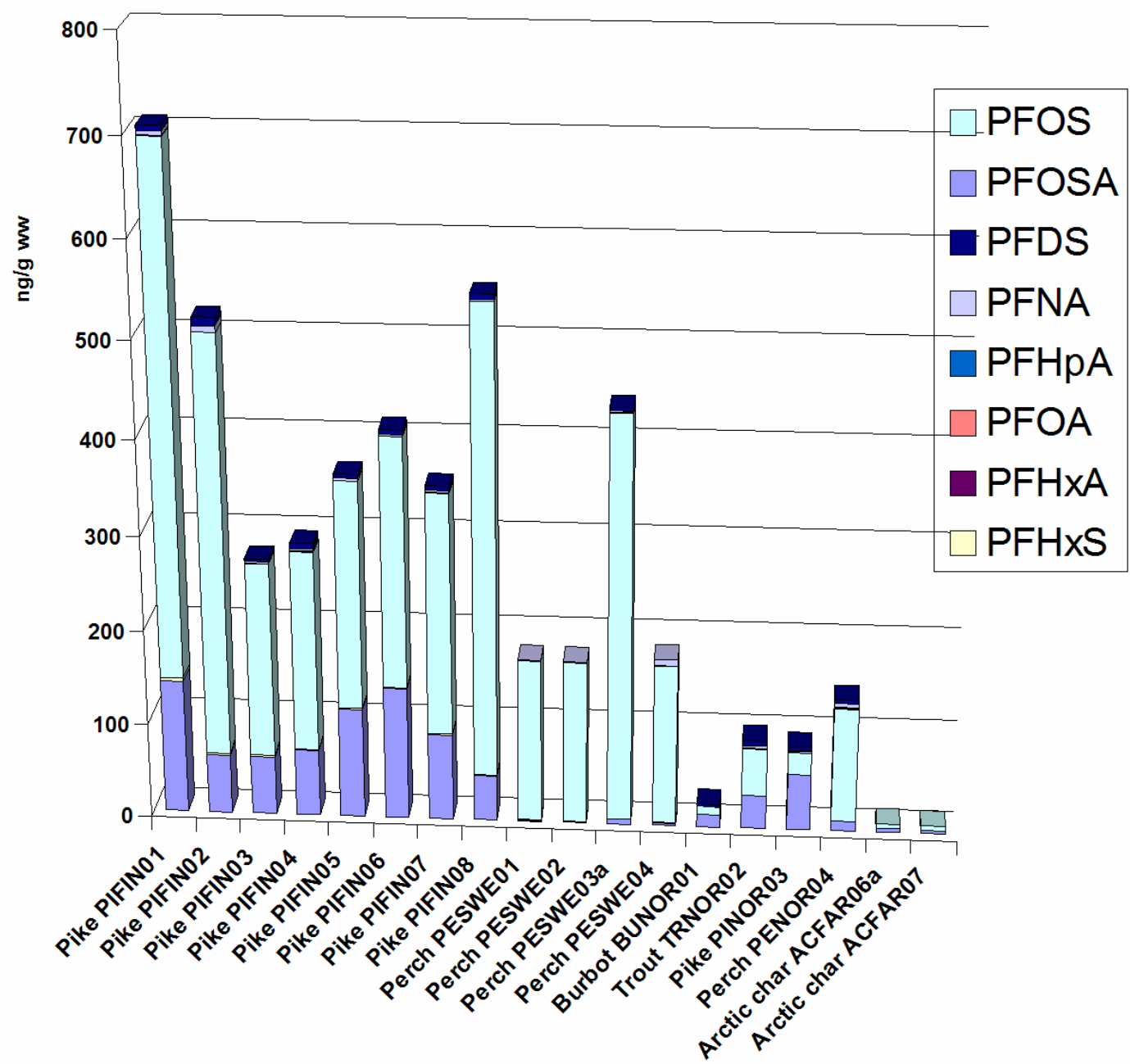

Figure 7: Compound specific level distribution for PFAS residues in freshwater fish liver: Pike (Fin=8, $\mathrm{NO}=1)$, perch $(\mathrm{SWE}=4, \mathrm{NO}=1$,), trout $(\mathrm{No}=1)$, landlocked Arctic char $(\mathrm{FAR}=2)$ and burbot $(\mathrm{NO}=1)$. Concentrations are given in $\mathrm{ng} / \mathrm{g}$ ww. For more information on the sample characteristics see appendices.

Norwegian and Swedish perch showed comparable PFAS concentration and patterns. However the contamination level in the one Norwegian pike sample is considerably lower as found for the Finnish pikes. In addition, PFOS is not the dominating PFAS residue (but PFOSA) in the Norwegian Pike sample as already mentioned before. In addition, the fact that PFOS and PFOSA were also detected in anadromous Arctic char in the Faroe Islands indicate that long-range transport in air and/or precipitation is occurring.

\section{Marine fish}

The PFAS distribution in marine fish species (liver samples) is characterised by a surprisingly high variability reflecting differences in food chain, food habits and transformation strategies. Also for marine fish species, PFOS represents in most cases 
the predominant representative of the PFAS contamination (figure 8). However, in Sculpins, PFOSA is the found as the highest PFAS contaminant. Also for the Atlantic cod sample from the Faroe islands PFOSA is higher concentrated than found for the Swedish cod samples (Figure 8). The highest PFAS levels were found for a Swedish $\operatorname{cod}(\mathrm{COSWE} 12 ;$ PFOS $=62 \mathrm{ng} / \mathrm{g} \mathrm{ww}$ ) and a Danish Eelpout (EPDAN05; PFOS $=60$ $\mathrm{ng} / \mathrm{g} w w)$. Danish Eelpout and Herring contained also measurable amounts of minor PFAS contributors like PFHxA and PFOA. In Long-rough dab and sculpin from Iceland PFHxA is even one of the dominating PFAS contributors. However, PFHxA is not prevalent in the Icelandic dab sample. The marine fish samples from the Faroe Islands are the lowest contaminated samples measured with regard to PFAS. Country specific application pattern can, thus, not be excluded as important reason for pattern distribution and concentration levels.

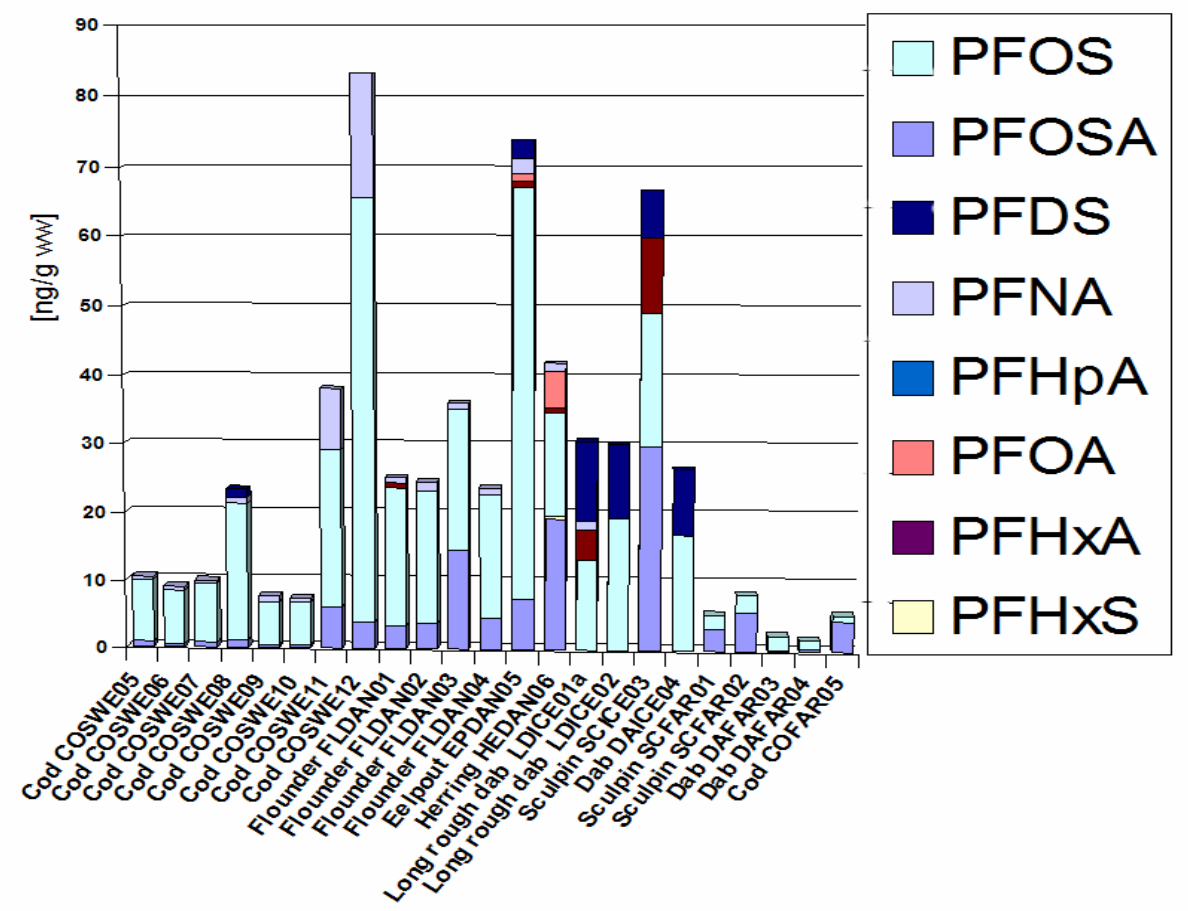

Figure 8: Compound specific level distribution for PFAS residues in marine fish liver [ng/ ww]. PFAS was determined in Atlantic cod $(\mathrm{SWE}=8, \mathrm{FAR}=1)$, Herring $(\mathrm{DAN}=1)$, Flounders $(\mathrm{DAN}=4)$, Eelpout $(\mathrm{DAN}=1)$, Long-rough dab $(\mathrm{ICE}=$ 2), Sculpin ( $\mathrm{ICE}=1, \mathrm{FAR}=2)$, Dab (ICE=1, FAR =2).

Nevertheless, marine fish species are significantly minor contaminated compared with the previously described freshwater samples indicating a certain correlation to the primary source distance. Please not that Perfluorodecane sulfone (PFDS) levels are surprisingly high in all Icelandic marine fish samples.

\section{Marine mammals}

The 17 marine mammal samples (liver samples) selected for the here presented PFAS screening represents the top predators of the marine environment. Marine mammals are considerably higher contaminated as the marine and fresh water fish samples previously described. However, Icelandic minke whales are characterised by a relatively low PFAS contamination compared with the pilot whales from the Faroe Islands (figure 9) indicating a correlation to the position in the food chain and food habits. Swedish and Danish grey seals are highest contaminated with PFAS residues. The highest PFOS 
values were found in Danish Harbour seal samples (HSDAN10; PFOS = $977 \mathrm{ng} / \mathrm{g} \mathrm{ww}$ ). Usually PFOS is the dominating PFAS residue also in marine mammals. However in Pilot whales from the Faroe Islands, PFOSA is equally contributing to the PFAS burden in two cases even exceeding the PFOS levels considerably (PWFAR08; PFOSA $=218$ ng/g ww and PWFAR09; PFOSA = 364 ng/g ww).

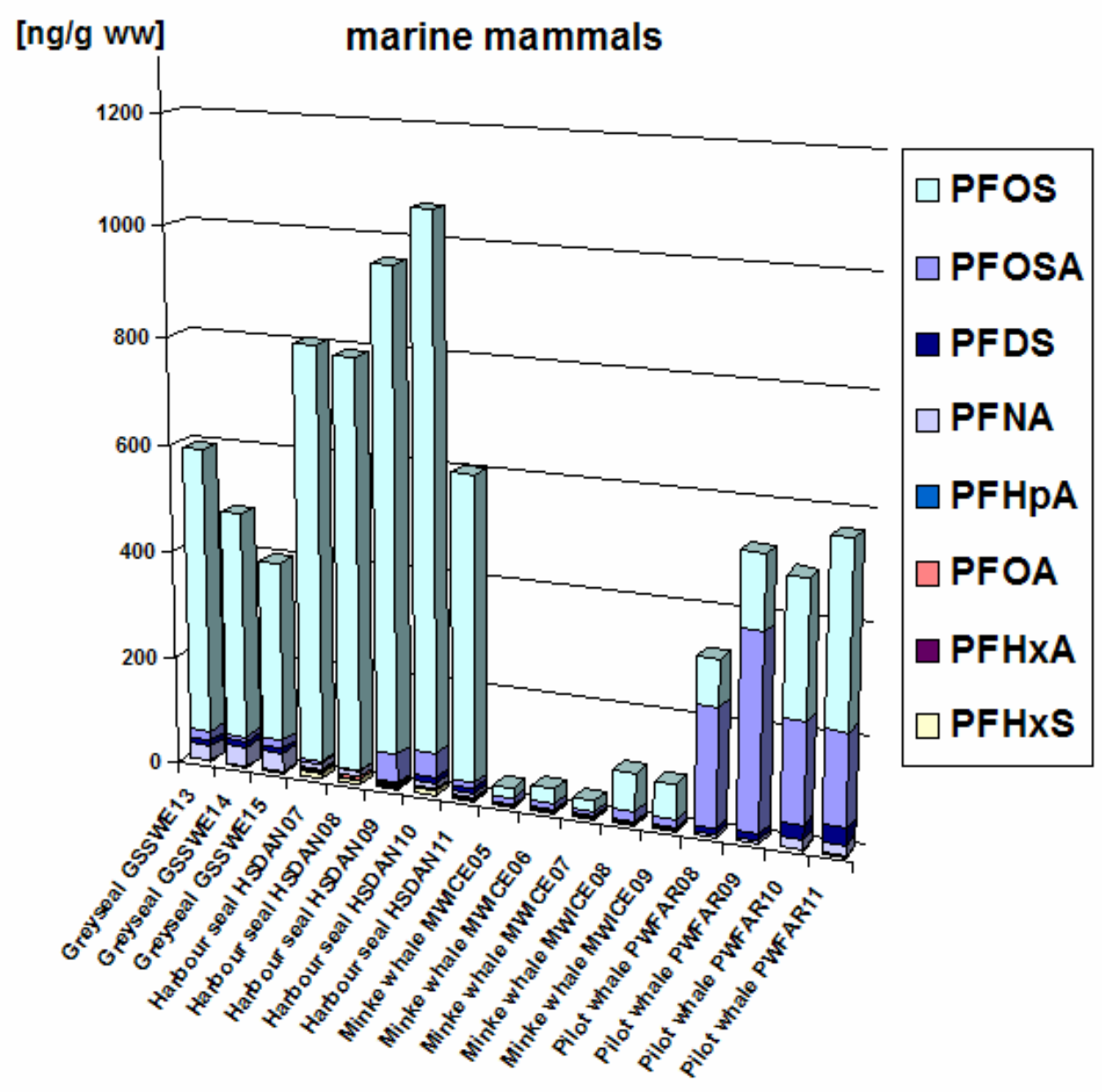

Figure 9: Compound specific level distribution for PFAS residues in marine mammals (livers): Harbour seals (Denmark), grey seals (Sweden), minke whales (Iceland) and pilot whales (Faroe Islands).

In all marine mammal samples, PFDS, a perfluorinated residue with a long-alkylated chain, is found in considerable amounts indicating bioaccumulation potential for this type of PFAS contaminants. Also hexanoic compounds (PFHxS and PFHxA) are found in measurable concentrations in all sample types (highest in harbour seals).

\section{Marine birds}

Two Fulmar samples (pooled eggs) were collected as pooled samples at the Faroe Islands. The PFAS levels were found in the sample concentration range as for marine fish species (Figure 10). Although PFOS is also for Fulmars the predominant PFAS residue, PFOSA is not as dominant as found for the other biota samples. In Fulmars, PFNA is the second highest PFAS contaminant. Nevertheless, PFOS stands for about 95 $\%$ of the PFAS contamination in the Fulmar samples from the Faroe Islands. 


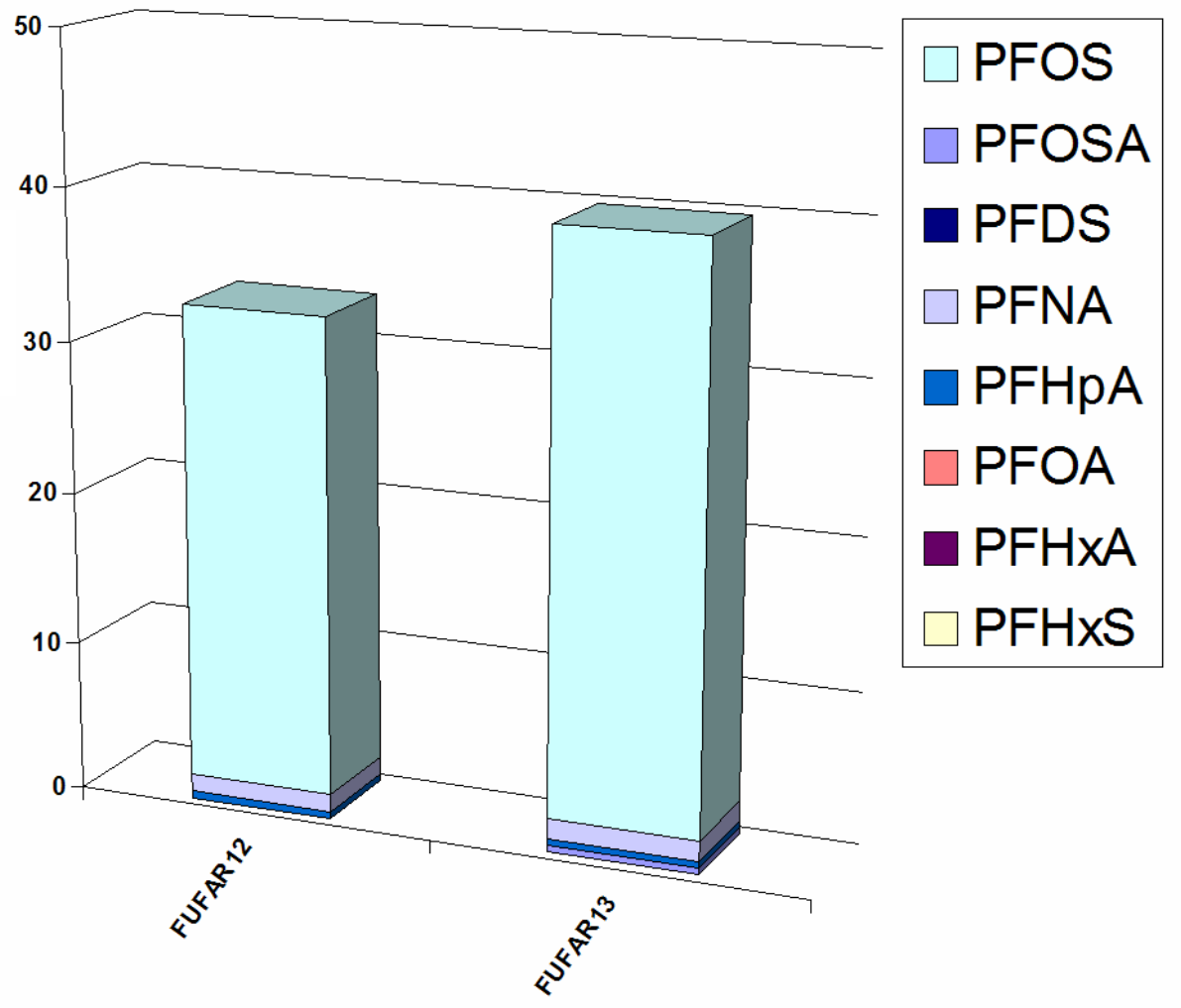

Figure 10: Compound specific level distribution for PFAS residues in pooled Fulmar egg samples from the Faroe Islands [ng/g ww]. 


\section{Discussion and recommendations}

The first Nordic screening on fate and distribution of PFAS related residues in environmental samples confirmed that PFAS residues are widely present in the Nordic environment. The first overview indicates that sewage sludge and landfill effluents are contributing as important anthropogenic sources for the release of PFAS into the environment. Large amounts of PFAS related contaminants are, thereafter, deposited in sediment. Whether remobilisation from the sediments into the adjacent water column and the food web also is an important contribution remains still unknown at present. However, significant amounts of PFAS related chemicals mostly dominated by PFOS are accumulating in the marine and freshwater food web into the top predating organisms reaching surprisingly high concentration levels.

\subsection{Source elucidation}

Already during preparation of the presented Nordic PFAS screening, sewage and landfill was identified as major anthropogenic sources based on general literature survey. Thus, sewage sludge, sewage effluent and landfill effluent was collected to document the concentration burden in this specific sample types representing primary environmental releases (figure 11-13).

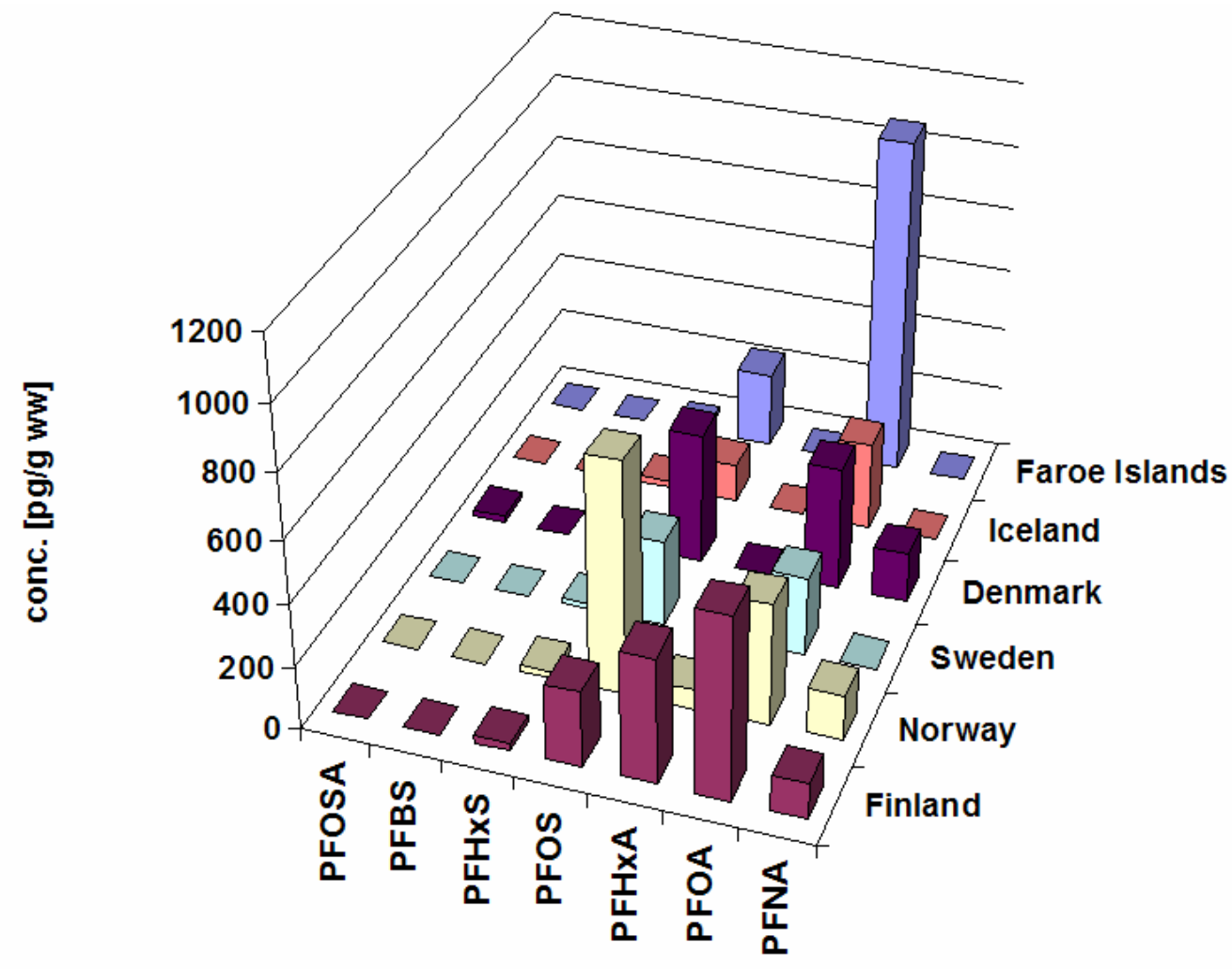

Figure 11a: Median distribution [pg/g ww] compounds in Nordic sewage sludge samples. 


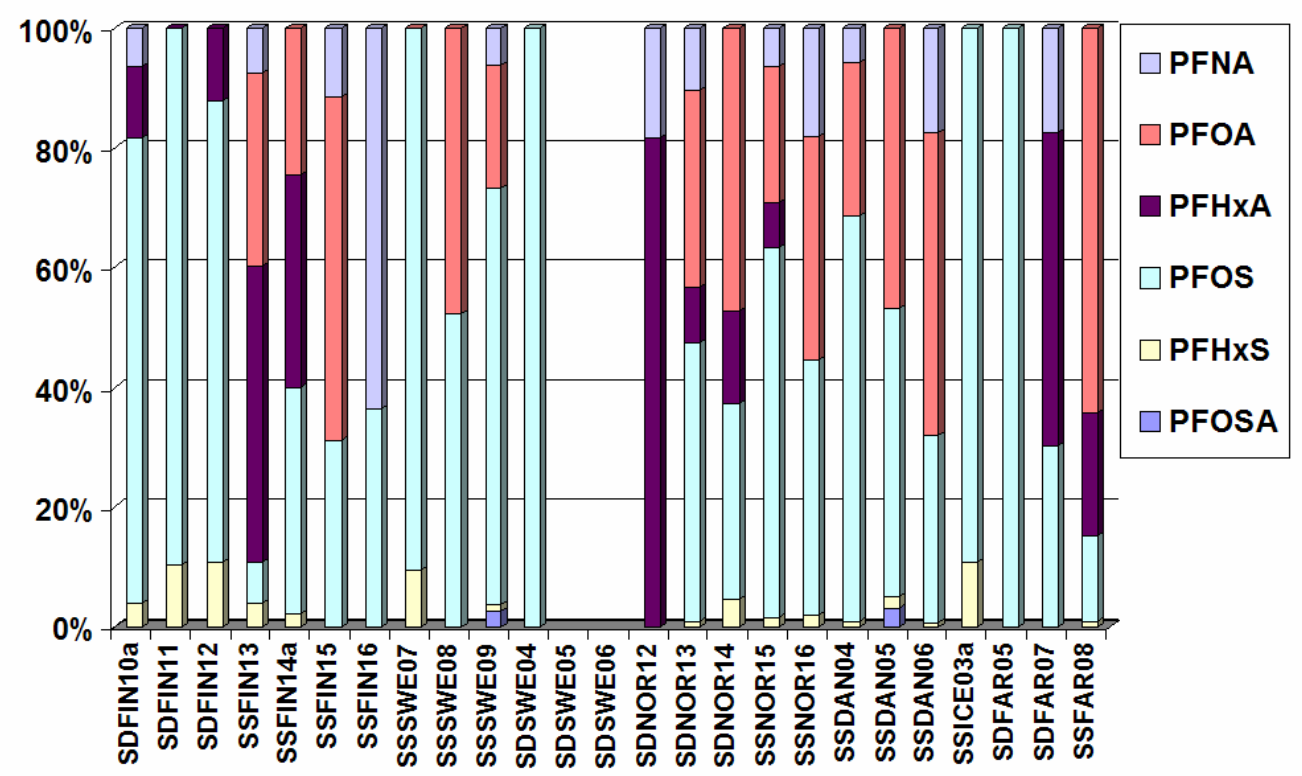

Figure 11b: Percentage distribution of PFAS related residues in Nordic abiotic solid samples $(\mathrm{SS}=$ sewage sludge and $\mathrm{SD}=$ sediment $)$.

A first comparison of PFAS contamination in sewage sludge collected in 6 different Nordic countries revealed significant pattern differences. In general PFOS was the predominant PFAS residue in sewage sludge (figure 11a-b). On the other hand, PFOA, is the predominant PFAS residue in some Finish, Danish and Faroe Island sewage sludge samples (SSFIN15, SSDAN06, SSFAR08). In few samples (SSFIN13, SDNOR12, SDFAR07) even PFHxA is dominating the PFAS pattern. These strong local variations in the PFAS distribution and levels indicate different sources or considerable temporal fluctuation in the release patterns.

Highest individual PFAS concentrations were found for a Swedish sludge sample (SUM PFAS SSSWE09 $=3793 \mathrm{pg} / \mathrm{g} \mathrm{ww}$, figure 4). The detected differences in pattern distribution point towards an application specific release pattern from anthropogenic sewage sludge sources into the environment with country specific influences. The PFAS distribution in sewage effluent samples reflect in general the concentrations found in sewage sludge from the different Nordic countries (Figure 12).

However, the median concentrations in the three sewage effluent sample sets are surprisingly homogeneous distributed (Figure 12). In both Norwegian and Finnish effluent samples, PFOA is the predominant PFAS constituent whereas PFHxA is equally concentrated as PFOS in the Finnish sewage effluent sample The sewage effluent sample from the Faroe island is considerably lower contaminated. The obvious shift in PFAS predominance from sewage sludge to sewage effluent (especially pronounced for the samples from the Faroe islands) indicated that also the physicochemical properties are important in the distribution and release of PFAS from primary sources like sewage sludge. PFOA and PFHxA are more soluble in aqueous samples than PFOS. Therefore, PFOA and PFHxA are distributed via the water phase whereas PFOS is assumed to be introduced into the environment mainly via biosolids adsorbed on surfaces. PFBS, the perfluorinated chemical promoted currently as successor for PFOS related products is found in significant amounts in all aqueous samples. 


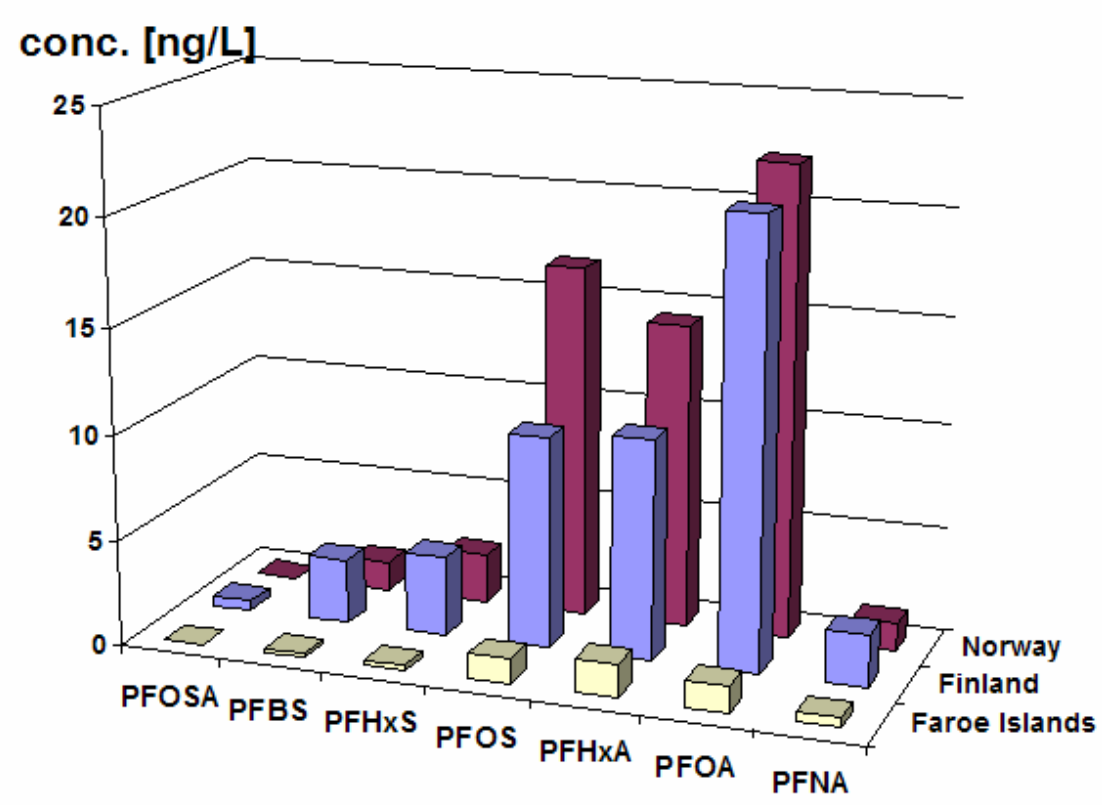

Figure 12: Median distribution [ng/L] compounds in sewage effluent

Landfill effluents are identified as additional possible anthropogenic sources (figure 13).

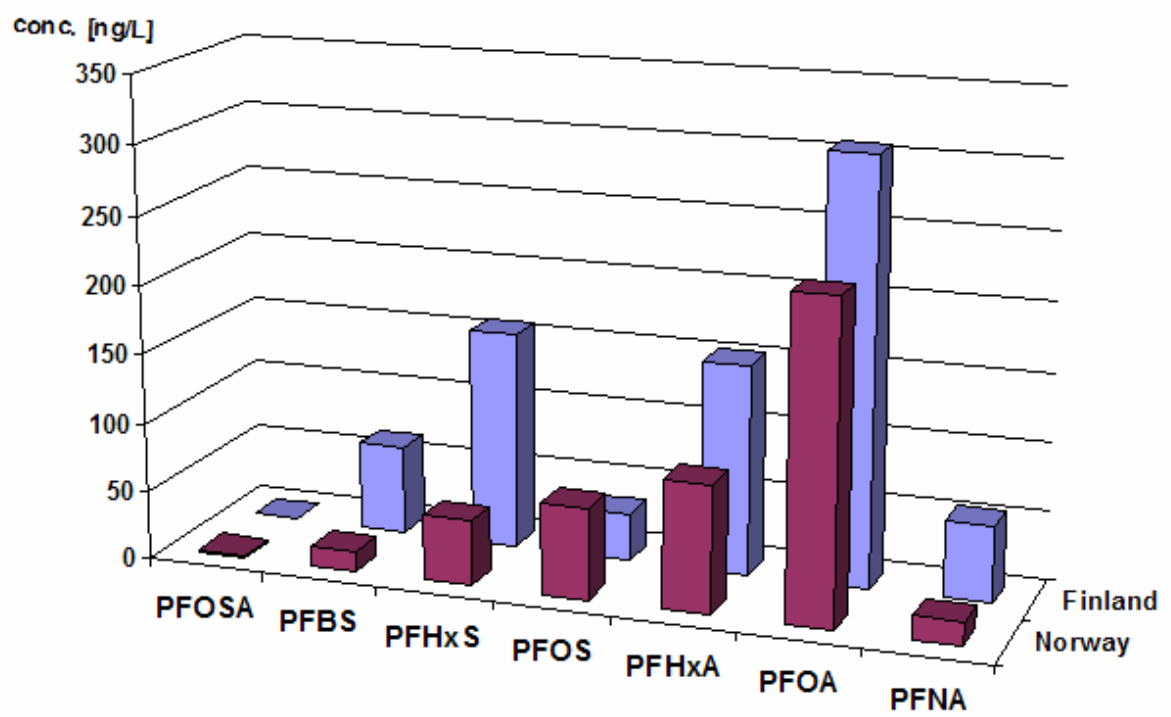

Figure 13: Median PFAS distribution [ng/L] in Nordic landfill effluent

The concentration levels found for the two sample sets of landfill effluent are considerably higher than the levels previously discussed for sewage effluents (around $10 \mathrm{x}$ higher, see figure 12) confirming the significant contribution of landfill effluent water as major anthropogenic source for PFAS in Nordic countries. PFHxS, PFHxA and PFOA are dominating the Finnish landfill effluent sample. In the Norwegian samples, PFOS, PFHxA and PFOA are dominating. PFOA is the predominant PFAS constituent in all landfill effluent. 


\subsection{Sample specific patterns and fate estimation}

The distribution of PFAS related residues in environmental samples is ruled by a combination of chemical, physical and biological processes including physico-chemical properties of the chemical, the physical environment (temperature, adsorption, storage medium, light-conditions) and biological accumulation and transformation processes.

\subsubsection{Potential sources}

Sewage sludge, sewage effluent and landfill effluents are identified as potential primary sources for the release of PFAS residues into the Nordic environment due to the high levels of PFAS related compounds detected in these sample types (figure 5 and 6).

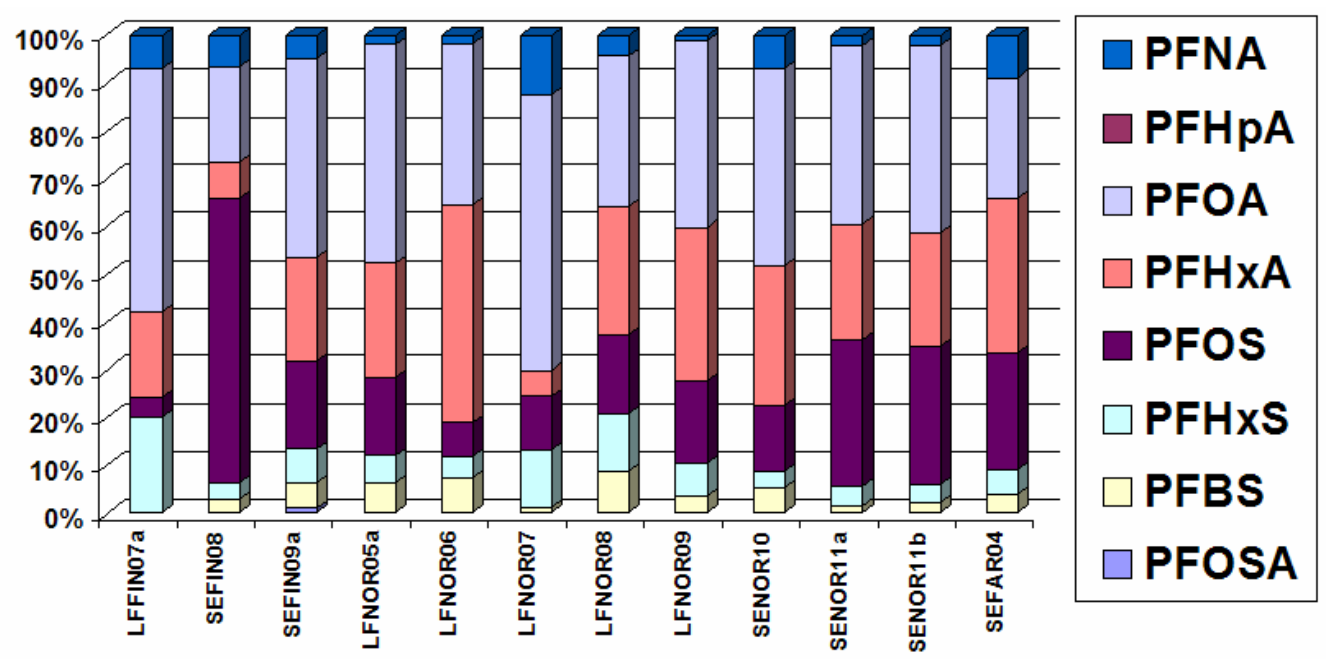

Figure 14: Relative pattern distribution of PFAS residues in Nordic sewage effluent and landfill effluent samples.

Based on the available data, the release pattern seems mainly governed by physicochemical properties of the target compounds in combination with application patterns characteristic for the respective Nordic country.

The PFAS patterns in sewage sludge (figure 11b), sewage effluent and landfill effluents are mainly ruled by PFOA, PFOS and PFHxA (figure 14). Sewage sludge from Finland is dominated by PFOA whereas Swedish sewage is dominated by PFOS. Norwegian sewage effluent samples are dominated by PFOA and PFOS. Sewage effluents from Finland do not reflect the characteristic patterns found for the respective sewage sludge samples indicating a strong "day-to-day" fluctuation in the release patterns and amounts.

Relative high concentration levels were found in marine mammals, which usually express strong migration behaviour. In addition, the concentration ranges reported on a global basis (Giesy et al. 2001) in combination with the here presented data set indicate that already now many PFAS related residues (PFOS, PFOSA) must be considered as ubiquitously distributed throughout the globe and thus, long-range transport (e.g., ocean currents, atmosphere) is expected to be a major source for PFAS contamination in remote places such as the Arctic regions. 


\subsubsection{Seawater, fresh water and rain water samples}

Adjacent water bodies serve as direct recipients of the sewage and landfill related environmental release. However, except for one seawater sample (SWFIN01), the water samples (seawater, lake water, precipitation) do not reflect the primary release pattern identified for the previously described sewage and landfill samples (figure 14 and figure 15). The PFAS pattern in all Swedish and Finnish precipitation samples (rainwater) are governed by PFOA (Figure 15).

\section{A.: $\quad$ Seawater}
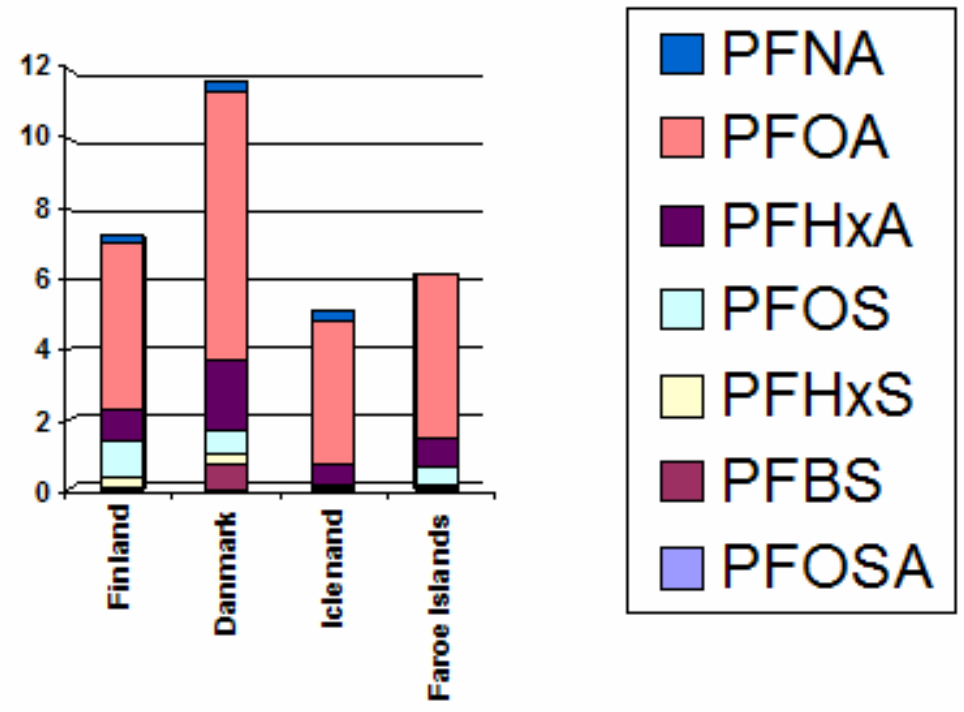

B
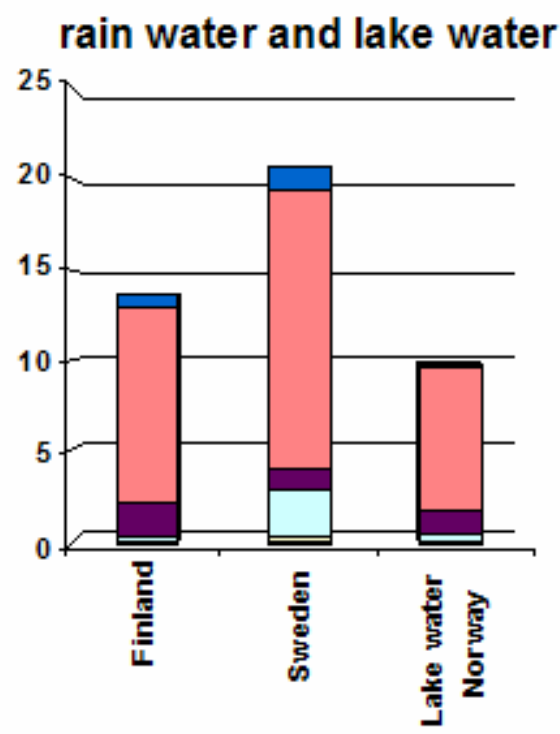

Figure 15: A: Median concentrations for seawater; B: rain (Sweden) and lake water/ fresh water samples (Finland, Norway). Concentration are given in ng/L.

Whereas no clear pattern distinction between lake water, rain water and seawater could be established regardless location (where the samples have been collected). 


\subsubsection{Sediment}

The median distribution (Figure 16) showed that the PFAS levels in sediment are different in the respective Nordic countries. PFOS is only dominating in the Finnish sediment samples. In the Norwegian samples, PFOA is the predominant PFAS residue, whereas the lowest levels were found in sediments from Sweden with PFOS as the predominant PFAS constituent. Low PFAS levels were also found in Faroe Island sediments with PFOSand PFHxA as dominating compound.

PFOS was identified as important PFAS related pollutant in sediments representing in all samples the predominant or the second most concentrated PFAS contaminant in all sediments analysed.

Whether these distinct differences are a result of the differences in sediment composition or a result of country specific release patterns remains unknown und should be investigated in more detail.

\section{Median distribution: Sediments}

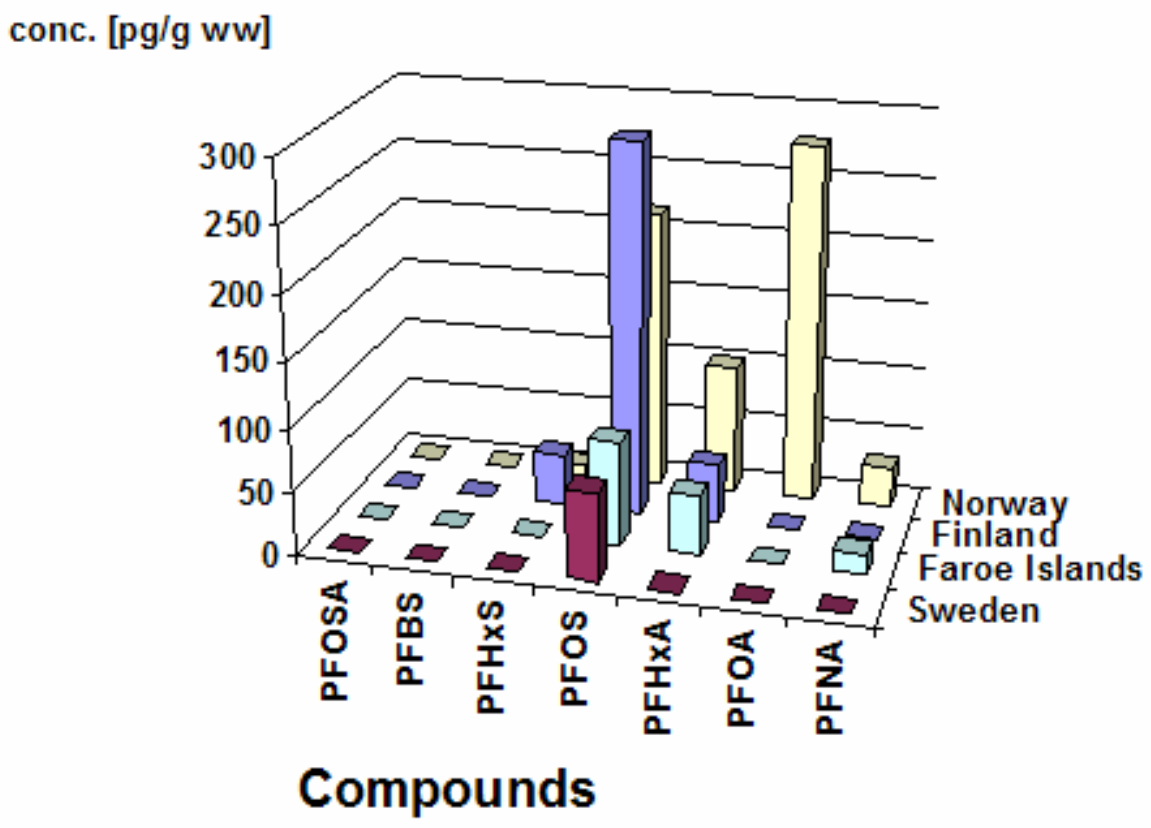

Figure 16: Median PFAS concentrations in Nordic sediment samples.

\subsubsection{Biota}

A complex combination of trophic level, up-take via the food web, passive accumulation processes as well as bioconcentration is assumed to rule the PFAS patterns in the Nordic biota samples. 

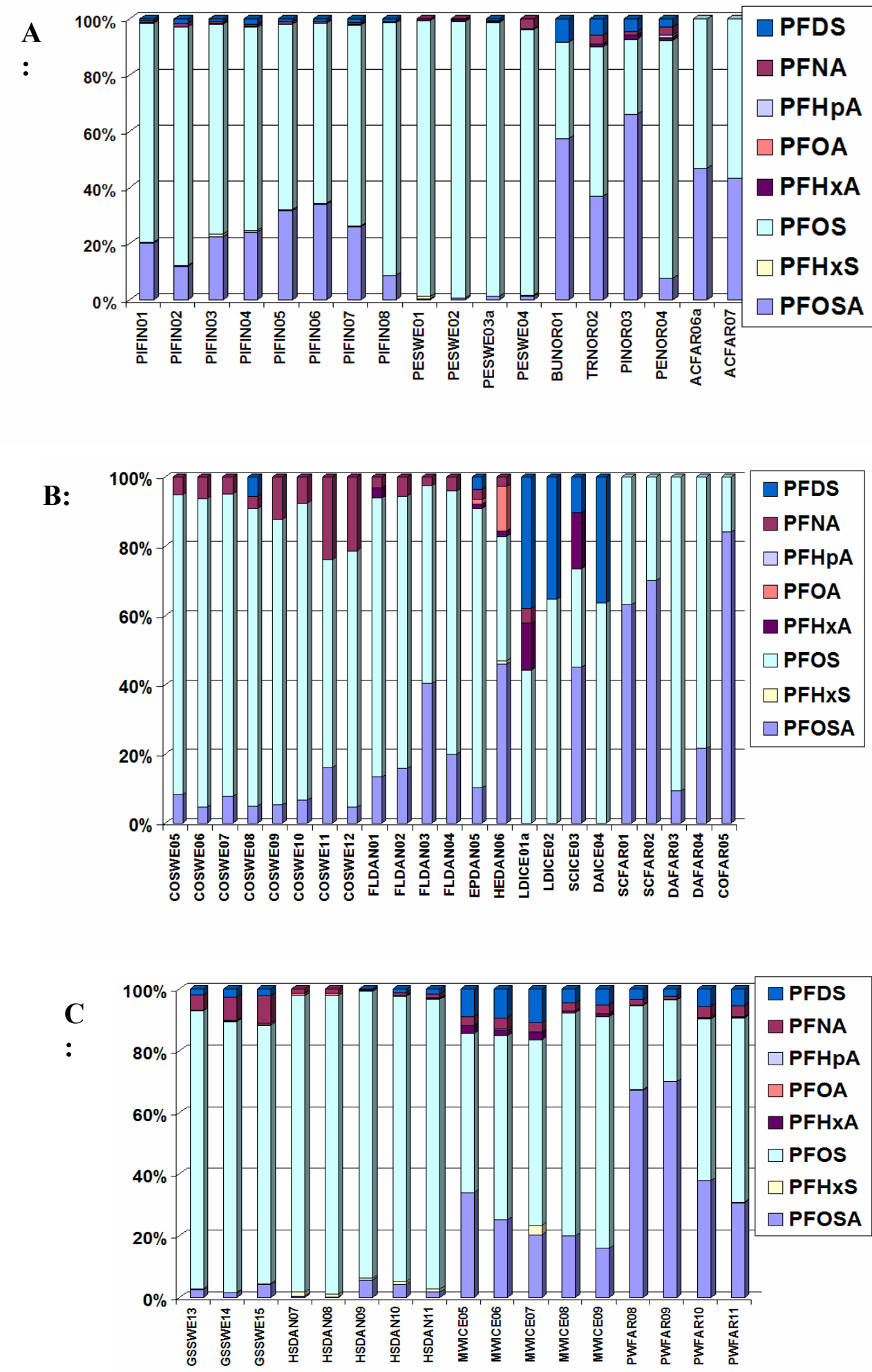

Figure 17: Reative pattern distribution for PFAS residues in freshwater fish (A), marine fish (B) and marine mammals (C).

For samples codes see page 33-34

PFAS pattern in the various biota samples reflect the biological status of the species and not so much the sample location/ country. A first pattern analysis revealed that species representing high trophic levels (top predators) are mainly dominated by PFOSA and 
PFOS (figure 17a-c). Danish harbour seals and Swedish grey seals are dominated by PFOS whereas PFOSA is predominant in Pilote whales from the Faroe Islands. Also Finnish pike samples are strongly influenced by PFOS. Marine and freshwater fish species representing lower trophic levels seem not as strongly influenced by PFOS and PFOSA as top predating species.

PFOS and PFOSA are present in the fresh water pike and perch in almost as high concentrations as in the marine mammals. These high burdens are probably due to primary source in the vicinity of the sampling site. However, the diversity of PFAS found in the marine fish and mammals seems to be higher than in the fresh water fish reflecting a stronger influence of possible secondary sources like long-range transport (atmosphere and ocean currents) as well as migration patterns of marine species (predators and prey species).

\subsection{Spatial distribution}

A first attempt to find indications for country specific distribution pattern is undertaken. Only for sample types collected and analysed from more than 3 Nordic countries a comparison of the results has been performed. However, statistically the available data set is by far not sufficient to reveal significant and statistically confirmed spatial trends. Thus, the here presented tendencies and patterns should only be considered as indications and used as basis for later in-depth trend studies.

\subsubsection{Seawater}

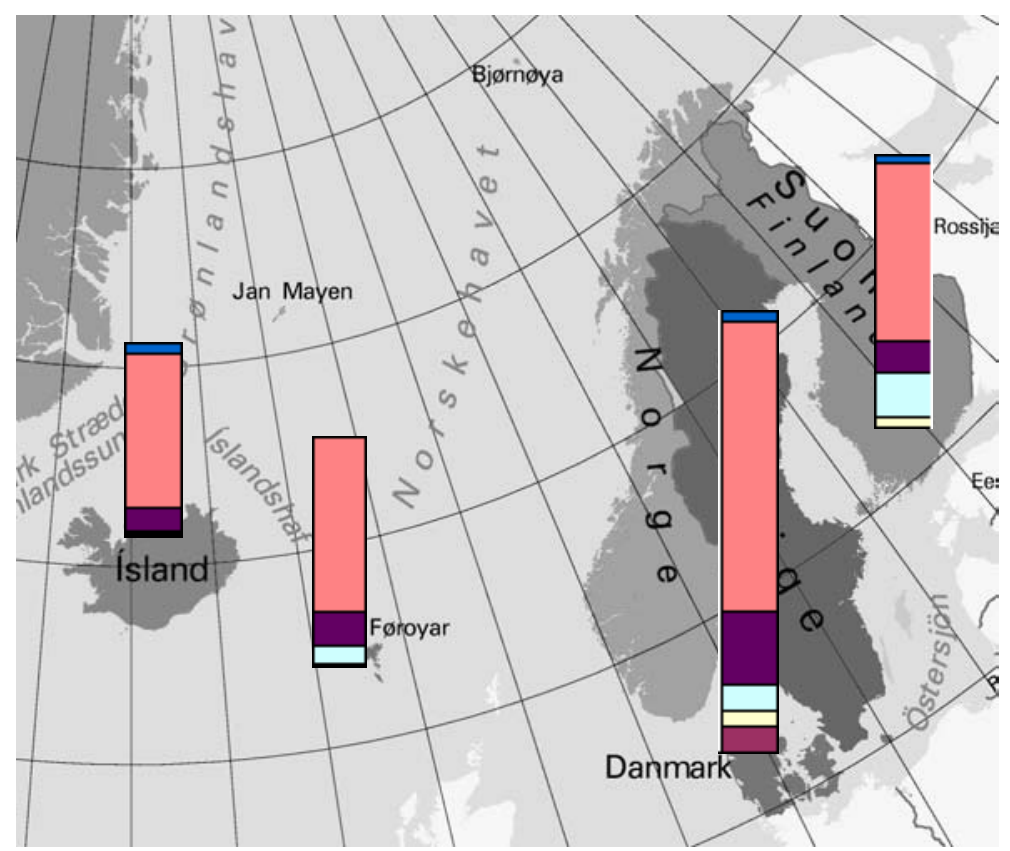

ng/L

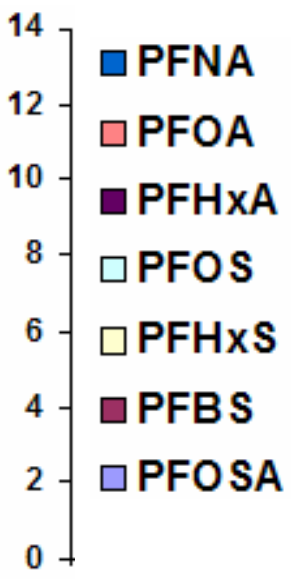

Figure 18: Spatial distribution of PFAS residues (ng/L median concentrations) in seawater from Nordic countries.

Please note, the placement of the histograms in the map does not reflect any information on sampling location.

In general, the PFAS median values for seawater samples collected in Iceland, Faroe Islands, Denmark and Finland reflect a similar PFAS distribution pattern (Figure 18). PFOA is dominating all seawater samples analysed (up to $70 \%$ of the PFAS burden) 
usually followed by PFHxA. However, in the Finnish samples, PFOS is slightly higher concentrated than PFHxA. The overall concentrations for PFAS are highest in Finland and Denmark indicating a certain influence of the population density. However, The concentration differences between the countries with smaller populations (Iceland, Faroe Islands) and larger populations (Denmark, Finland) are surprisingly small (around factor 2). Thus, the contribution of PFAS burdens from long-range transport may be considered and investigated as import source in future investigations.

However, sampling specific circumstances (e.g., distance to potential sources, sea currents, tidal conditions etc.) may contribute to the small differences between PFAS levels found in seawater.

\subsubsection{Sewage sludge}

For many comprehensively investigated anthropogenic pollutants, sewage sludge is considered as a significant primary release source. Therefore, also for the here presented study, sewage sludge was considered as an important sample type and, thus, collected in all six participating countries. A direct correlation between population size contributing to the sewage treatment plant (person equivalents) or specific sewage treatment procedures with the PFAS pattern found in sewage samples was not established in the here presented study. However, indications reflecting possible country specific application and release patterns are obvious (figure 19). The concentrations found in sewage sludge are relatively high amounting up to the lower micro-gram per gram (wet weight) range.

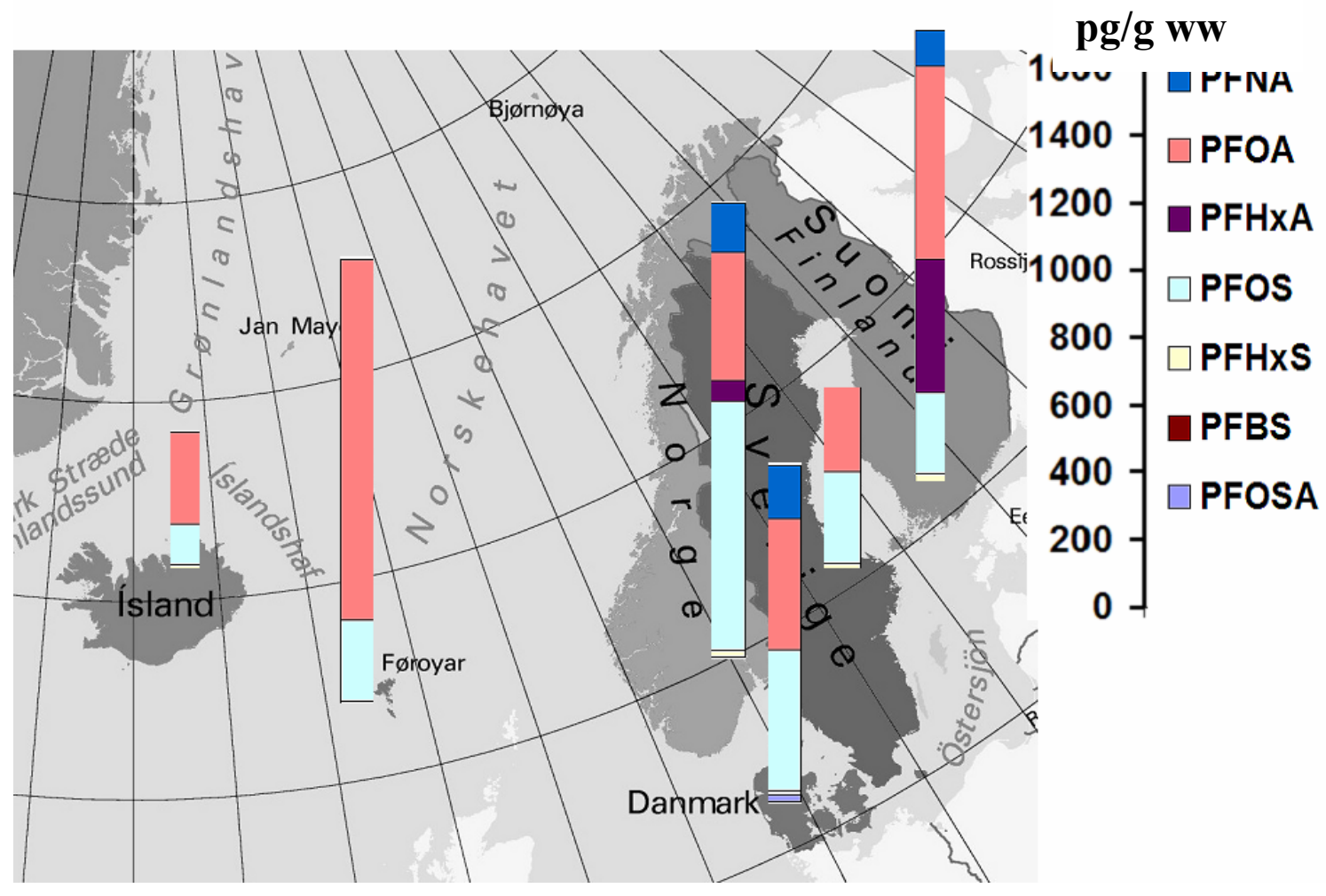

Figure 19: Spatial distribution of PFAS residues (pg/g ww median concentrations) in sewage sludge from Nordic countries.

Please note, the placement of the histograms in the map does not reflect any information on sampling location 
In the median distribution presented in figure 20, usually PFOA and PFOS were the predominant PFAS residues released through sewage sludge in all Nordic countries. However, whereas PFOA dominated in sewage samples from less populated countries (Iceland, Faroe Islands), PFOS was more prevalent in sewage from Denmark, Norway and Sweden). The PFAS burden of sewage from Finland, on the other hand, showed a somewhat different pattern. PFHxA is identified as second high concentrated PFAS residue in those samples indicating different release patterns (Figure 19). PFNA was also found insignificant amounts in Norwegian, Danish and Finnish Sewage (up to 10\% of the PFAS burden).

When comparing concentration ranges for PFOS, relatively similar concentration ranges were confirmed for Nordic countries with large population numbers (Norway, Sweden, Denmark and Finland). For Iceland and the Faroe Islands very low levels were found (table 15).

Table 15: Concentration ranges for sum PFOS in Nordic sewage sludge samples

\begin{tabular}{|l|l|l|}
\hline Country & Number of sampling locations & Concentrations [pg/g ww] \\
\hline Norway & 2 & $449-1023$ \\
\hline Denmark & 3 & $316-1041$ \\
\hline Sweden & 3 & $167-2644$ \\
\hline Finland & 3 & $35-925$ \\
\hline Iceland & 2 & $<$ LOQ - 220 \\
\hline $\begin{array}{l}\text { Faroe } \\
\text { Islands }\end{array}$ & 1 & 241 \\
\hline
\end{tabular}

\subsubsection{Sediment}

Sediment samples were collected from five Nordic countries. In the Icelandic sample no PFAS were detected and only in one Swedish sample PFOS was at a quantifiable level. PFAS levels found in Norwegian Freshwater sediments were surprisingly high with up to $637 \mathrm{pg} / \mathrm{g}$ ww (sum PFAS median concentrations) for these sediment samples (figure 20).

However, a spatial comparison of PFAS levels in sediment samples is difficult since in general sediment composition, sedimentation rate, depth of the water column, etc. play as significant role in the up-take rates and residence time of persistent contaminants in those environmental compartments.

In sediments from the Faroe Islands, Sweden and Finland, PFOS is the predominant PFAS residue followed by PFHxA. In Swedish samples, even PFOS only was detected. The Norwegian and Swedish sediment samples were collected from freshwater lakes. The Norwegian sediments were collected from the largest freshwater lake in Norway, lake Mjøsa. The Swedish samples showed exclusively PFOS as dominating residue. The Norwegian sediments, however, are dominated by PFOA, with considerable contributions of PFOS and PFHxA. Also PFNA was founding at significant levels. It can be assumed that, hydrological conditions (tidal patterns, currents), sediment composition, sedimentation rates etc. are significantly different in freshwater sediments compared to the ocean-borne sediments from the Baltic Sea (Finland), and the Atlantic 
Ocean (Faroe Islands and Iceland). Thus, no ocean current long-range transport contributes to and no tidal currents dilutes the PFAS burden deposited in the fresh water sediments from Lake Mjøsa (Norway) and the Swedish sites, whereas ocean-borne transport can be assumed contributing significantly to the PFAS patterns and burden in sediments from Finland and the Faroe Islands.

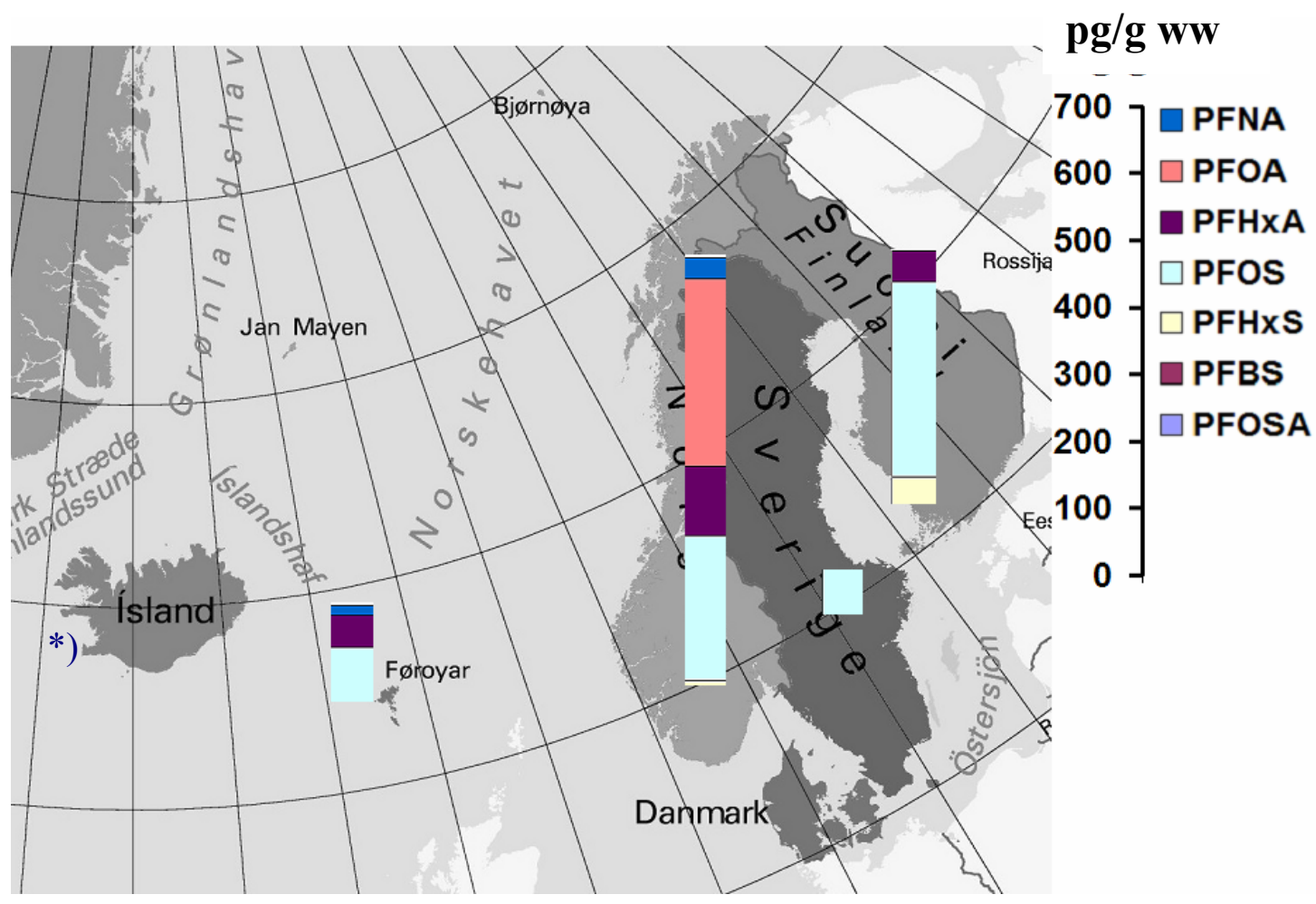

Figure 20: Spatial distribution of PFAS residues in sediment (pg/g ww median concentrations) from Nordic countries.

*) In the Icelandic sediment samples analysed, very low amounts of PFAS were found (see appendix 3).

Please note, the placement of the histograms in the map does not reflect any information on sampling location

\subsubsection{Biota}

Specimens of 16 different species were collected representing marine and fresh water environments. Samples from 6 species were collected from 2 different Nordic countries. Therefore, a comprehensive spatial distribution analysis is not possible based on the biota samples collected for the here presented Nordic PFAS screening exercise. However, the restricted data available are useful as indications for level distribution of PFAS in biota which should be subject for further elucidation.

In pike collected from Norway and Finland, the total PFAS concentration and contribution of PFOS to the overall PFAS burden is different (figure 21) indicating differences in primary sources and/or feeding habits. 


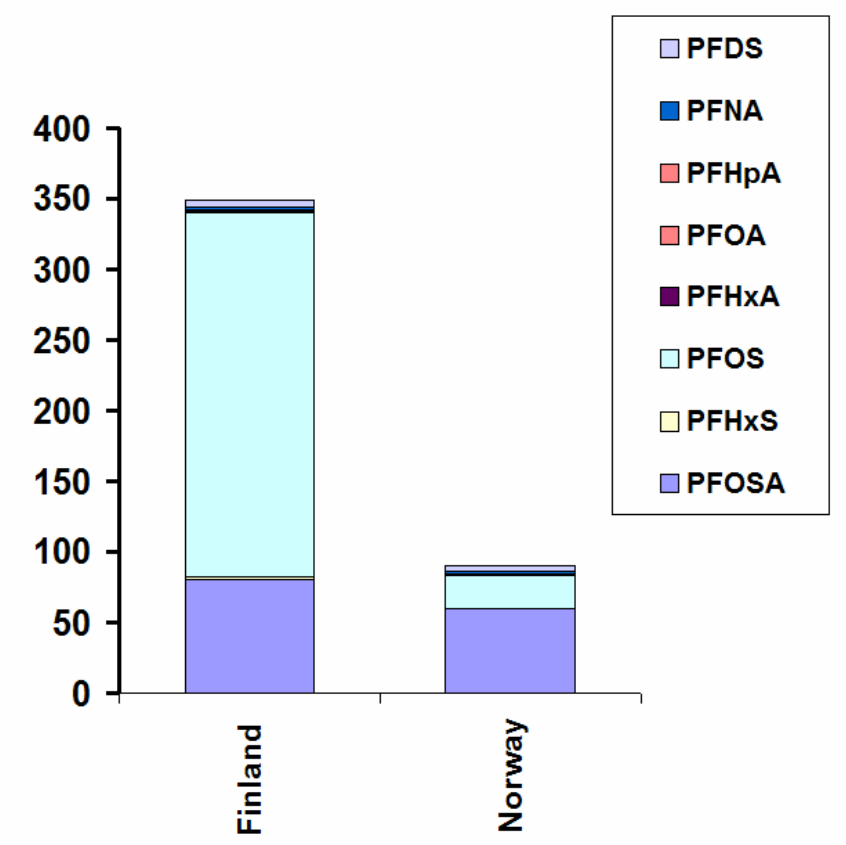

Figure 21: Median distribution of PFAS in Pike liver [ng/g ww] from Finland $(\mathrm{n}=8)$ and Norway $(\mathrm{n}=1)$.

The Finnish pike samples are higher contaminated with PFAS as the Norwegian sample. However, whereas the PFOSA levels are in a similar concentration range in pike liver from both countries, PFOS contributes with 10x higher levels to the overall PFAS burden in the Finnish pikes. The concentration levels in these freshwater fish were surprisingly high, found in the same concentration range as for top predating marine mammals (grey seal liver), indicating a considerable release of PFAS into freshwater system pointing towards different contamination sources. However, these preliminary assumptions are based on a very small data set and, thus, should only be considered as indication.

The levels in Atlantic cod were found in general to be low (low ng/g ww range). The Swedish cod samples were collected in the Baltic Sea, a region where many potential primary source are expected to release PFAS related residues in the marine environment close to the natural habitats of the cod. Thus, the levels of PFAS (median values from eight samples) in the Swedish cods were about 2 times higher than in the cod liver sample from Torshavn harbour (Faroe Islands, Figure 22). Whereas PFOS was the predominant PFAS contributor to the Swedish samples, PFOSA dominated in the Cod sample from the Faroe Island indicating different sources for respective populations. 


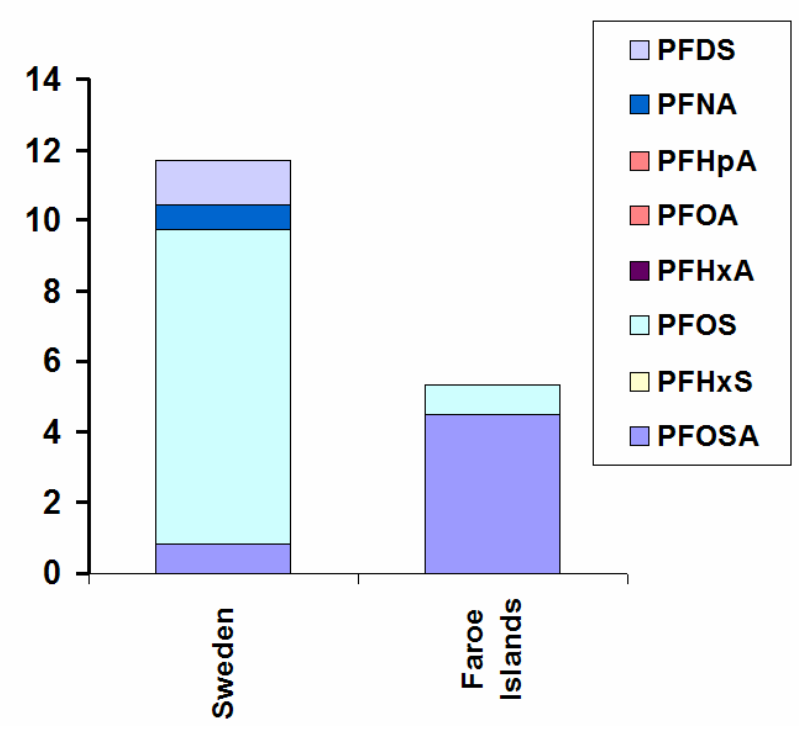

Figure 22: Median distribution of PFAS in Atlantic cod liver [ng/g ww] from the Faroe Islands $(n=1)$ and Sweden $(n=8)$.

In all other biological samples analysed for PFAS residues, no clear signals for county or region specific PFAS patterns and levels were identified.

\subsection{Comparison with literature data}

Until today only few reports are published and, thus, publicly available on the distribution of PFAS related residues in environmental sample. A first attempt is, therefore, made to compare the results of the Nordic PFAS screening with already available literature data reporting PFAS levels in comparable environmental matrices. However, due to the comprehensive analytical challenges posed by this specific group of environmental residues, the trace analytical methods available today are still in the stage of development. Thus instrumental differences in analytical methods used, method validation documented and quantification methods applied restrict a comprehensive comparison of the literature data available. Therefore, the here presented comparison should only be considered as indicative. More up-to-data international investigations (like the here presented Nordic screening exercise) are on the way, which, hopefully, will allow in future a more thorough comparison and evaluation of global distribution, fate and occurrence of PFAS related environmental contaminants.

\subsubsection{Water}

Several published scientific papers report on PFAS reported contaminants in aqueous samples. Three international studies from Germany, USA and Japan are identified which reported environmental concentration of PFAS residues (table 16). 
Table 16: Concentration distribution of selected PFAS residues in aqueous samples $[\mathrm{ng} / \mathrm{L}]$

\begin{tabular}{|c|c|c|c|c|c|c|}
\hline Matrix & Location & PFHxS & PFOS & PFOA & PFOSA & Reference \\
\hline $\begin{array}{l}\text { Surface water } \\
\text { (freshwater) }\end{array}$ & Germany & - & $2-43$ & LOD -8 & - & $\begin{array}{l}\text { Lang et al. } \\
2004\end{array}$ \\
\hline $\begin{array}{l}\text { Tennessee } \\
\text { upstream of } \\
\text { fluorofactory }\end{array}$ & $\begin{array}{l}\text { USA, } \\
\text { Tennessee } \\
\text { river }\end{array}$ & - & $17-54$ & $<25$ & - & $\begin{array}{l}\text { Hansen et al. } \\
2002\end{array}$ \\
\hline $\begin{array}{l}\text { Marine surface } \\
\text { water }\end{array}$ & Japan & $<11$ & LOD - 59 & - & - & $\begin{array}{l}\text { Taniyasu et } \\
\text { al. } 2003\end{array}$ \\
\hline $\begin{array}{l}\text { Nordic sea } \\
\text { water }\end{array}$ & $\begin{array}{c}\text { Nordic } \\
\text { countries }\end{array}$ & $0.08-4.39$ & $<L O D-21.7$ & $3.53-8.48$ & $<L O D-0.07$ & This study \\
\hline $\begin{array}{l}\text { Nordic lake } \\
\text { water }\end{array}$ & Norway & $<L O D-0.11$ & $<L O D-0.48$ & $4.82-8.23$ & $<L O D$ & This study \\
\hline $\begin{array}{l}\text { Nordic } \\
\text { precipitation }\end{array}$ & $\begin{array}{l}\text { Nordic } \\
\text { countries }\end{array}$ & $<L O D-0.59$ & $0.24-2.97$ & $8.23-16.8$ & $<L O D-0.14$ & This study \\
\hline
\end{tabular}

The German and the US study reported PFAS levels in freshwater, whereas the Japanese study focused on PFAS residues in marine surface water samples. In the literature data on fresh water used for this comparison PFOS was the predominant PFAS constituent. No distinct differences between freshwater and seawater (surface) is found in the literature references. These results are different compared to the here presented Nordic data set. However, the literature values focus mainly on PFOS and no information about e.g. PFHxA is available by now. In all Nordic water samples (seawater, freshwater (lake) and precipitation), PFOA is the predominant PFAS residue followed by PFOS or PFHxA. The PFOS levels in the Nordic samples are considerably lower than reported in the three reference studies whereas PFOA values were in comparable concentration ranges as described in the literature (table 15). However, the relative high LOD for PFOA reported in the USA study (Tennessee) indicate considerable methodological limitations.

\subsubsection{Sediment}

Only one recent study has been identified in the literature so far reporting on PFOS and PFOA residues in sediment samples (table 16). A first comparison of these literature data with the here reported Nordic sediment data revealed that the sediment concentrations measured in the Nordic samples were considerably higher compared with the sediment samples analysed from The Netherlands. In-line with the literature data from the Netherlands PFOS is identified as dominating PFAS residue in sediment samples (table 17). However, a direct comparison of the two data sets is difficult because the Dutch sediment concentration levels are reported on dry weight basis, whereas the Nordic data set is based upon wet weight. In general, the Nordic sediment samples were higher contaminated than reported for the Dutch sediments, revealing considerable contamination potential in Nordic sediments. 
Table 17: Concentration distribution of selected PFAS residues in sediment samples $[\mathrm{ng} / \mathrm{g}] . \mathrm{dw}=$ dry weight, $\mathrm{ww}=$ wet weight

\begin{tabular}{|l|l|l|l|l|l|l|}
\hline Matrix & Location & PFHxS & PFOS & PFOA & PFOSA & Reference \\
\hline $\begin{array}{l}\text { Sediments/ } \\
\text { suspended } \\
\text { matter (dw) }\end{array}$ & $\begin{array}{l}\text { The } \\
\text { Netherlands }\end{array}$ & - & LOD -47 & LOD -24 & - & $\begin{array}{l}\text { Schrap et al. } \\
(2004)\end{array}$ \\
\hline $\begin{array}{l}\text { Nordic Sediment } \\
(\boldsymbol{w} w)\end{array}$ & $\begin{array}{l}\text { Nordic } \\
\text { countries }\end{array}$ & LOD $-\mathbf{4 5}$ & LOD $-\mathbf{8 9 2}$ & LOD $-\mathbf{3 1 2}$ & $<$ LOD & This study \\
\hline
\end{tabular}

\subsubsection{Sewage sludge}

Also for PFAS in sewage sludge only one relevant study (Germany) was identified for comparison with the here presented Nordic PFAS study. However, PFOS was analysed in the German study and the detection limit was extremely high (6000 ng/g dw). Thus, PFOS was not detected in any of the German samples. In the Nordic study, PFOS was the dominant PFAS related contaminant in sewage sludge, but the highest concentration found was below the detection limit of the German study, which, furthermore, is given on dry weight basis. This prevents any comparison of the two studies. In the Nordic sewage sludge samples PFOA was detected as the second dominant PFAS residue, whereas PFOSA and PFHxS were detected in levels up to $90 \mathrm{ng} / \mathrm{g}$ ww (table 18).

Table 18: Concentration distribution of selected PFAS residues in sewage sludge samples $[\mathrm{ng} / \mathrm{g}] . \mathrm{dw}=$ dry weight, $\mathrm{ww}=$ wet weight

\begin{tabular}{|l|l|l|l|l|l|l|}
\hline Matrix & Location & PFHxS & PFOS & PFOA & PFOSA & Referene \\
\hline $\begin{array}{l}\text { Sewage sludge } \\
\text { (dw) }\end{array}$ & Germany & - & $\begin{array}{l}<\text { LOD }(6000 \\
\text { ng/g dw) }\end{array}$ & - & - & $\begin{array}{l}\text { Schröder } \\
(2003)\end{array}$ \\
\hline $\begin{array}{l}\text { Nordic sewage } \\
\text { sludge (ww) }\end{array}$ & $\begin{array}{l}\text { Nordic } \\
\text { countries }\end{array}$ & $<$ LOD - 91 & $\mathbf{5 5 - 2 6 4 4}$ & $\begin{array}{l}<\text { LOD }- \\
\mathbf{1 0 7 5}\end{array}$ & $<$ LOD - 94 & This study \\
\hline
\end{tabular}

\subsubsection{Biota}

Most of the PFAS data found in scientific literature were reported for various biological samples. Based on this so far reported literature survey, an ubiquitous global distribution must be assumed for PFOS and related compounds (table 19). A set of 9 relevant scientific references reporting PFAS residues in biota was identified for the here presented literature comparison. One common feature was identified for all reported biota data. PFOS was the predominant PFAS residue identified in biota regardless sample type or trophic level. A first comparison confirmed, that the highest environmental PFAS burdens were found in marine mammal samples (table 19), although highest individual PFOS values were found for single marine fish samples. Taniyasu et al. (2003) reported up to $7900 \mathrm{ng} / \mathrm{g}$ ww in a Japanese fish liver.

Also for marine mammals, mainly PFOS was reported in international studies except for a study on Baltic seals were also residues for other PFAS related compounds were found (table 19). The PFAS (e.g., PFOS, PFHxA, PFOA, PFOSA) concentrations found in the Nordic seal samples (Denmark, Sweden) are found in the same concentration range as reported from the Baltic study. In the Nordic study, all seal samples have been found to be highest contaminated with PFAS residues of all Nordic biota analysed. 
Table 19: Concentration distribution of selected PFAS residues in biological samples $[\mathrm{ng} / \mathrm{g}] . \quad \mathrm{dw}=$ dry weight, $\mathrm{ww}=$ wet weight.

\begin{tabular}{|c|c|c|c|c|c|c|}
\hline Matrix & Location & PFHxS & PFOS & PFOA & PFOSA & Reference \\
\hline Bird liver (ww) & Korea/Japan & LOD - 34 & LOD -650 & LOD - 21 & $\begin{array}{l}\text { LOD - } \\
215\end{array}$ & $\begin{array}{l}\text { Kannan et al. } \\
(2002 c)\end{array}$ \\
\hline $\begin{array}{l}\text { Bird liver } \\
\text { worldwide (ww) }\end{array}$ & - & - & LOD - 690 & - & - & Giesy et al. (2001) \\
\hline $\begin{array}{l}\text { Fulmar, pooled } \\
\text { eggs (ww) }\end{array}$ & $\begin{array}{l}\text { Nordic } \\
\text { countries }\end{array}$ & $\angle L O D$ & $31-37$ & $<L O D$ & $\begin{array}{l}<L O D- \\
0.46\end{array}$ & This study \\
\hline Seal liver (ww) & $\begin{array}{l}\text { Baltic Sea/ } \\
\text { Bothnian Bay }\end{array}$ & $<7.5$ & $130-1100$ & LOD - 39 & $\begin{array}{l}\text { LOD - } \\
47\end{array}$ & $\begin{array}{l}\text { Kannan et al. } \\
\text { (2002a) }\end{array}$ \\
\hline $\begin{array}{l}\text { Seal/dolphin/ polar } \\
\text { bear/ otter liver } \\
\text { (ww) }\end{array}$ & $\begin{array}{l}\text { Worldwide } \\
\text { survey }\end{array}$ & - & LOD - 990 & - & - & Giesy et al. (2001) \\
\hline $\begin{array}{l}\text { Dolphin liver } \\
\text { (ww) }\end{array}$ & $\begin{array}{l}\text { USA/Canada/ } \\
\text { Mexico }\end{array}$ & - & $37-1520$ & - & - & $\begin{array}{l}\text { Kannan et al. } \\
(2001 b)\end{array}$ \\
\hline $\begin{array}{l}\text { Minke whales } \\
(w w)\end{array}$ & $\begin{array}{l}\text { Nordic } \\
\text { countries }\end{array}$ & $<L O D-1.1$ & $19-71$ & $<L O D$ & $7.2-19$ & This study \\
\hline Pilot whales (ww) & $\begin{array}{l}\text { Nordic } \\
\text { countries }\end{array}$ & $0.39-1.0$ & $88-336$ & $0.35-1.7$ & $172-364$ & This study \\
\hline Seals (ww) & $\begin{array}{l}\text { Nordic } \\
\text { countries }\end{array}$ & $0.67-10$ & $331-977$ & $0.3-5.6$ & $0.93-55$ & This study \\
\hline Fish liver (ww) & worldwide & - & LOD - 170 & $\overline{-1}$ & - & Giesy et al. (2001) \\
\hline Fish liver (ww) & $\begin{array}{l}\text { The } \\
\text { Netherlands, } \\
\text { Western Scheldt }\end{array}$ & - & $>10-7760$ & - & - & Hoff et al. (2003) \\
\hline Oysters (dw) & USA & - & $\begin{array}{l}\text { LOD - } \\
1225\end{array}$ & - & - & $\begin{array}{l}\text { Kannan et al. } \\
\text { (2002d) }\end{array}$ \\
\hline Eel filet (ww) & The Netherlands & - & LOD - 143 & $<$ LOD & - & $\begin{array}{l}\text { Schrap et al. } \\
(2004)\end{array}$ \\
\hline $\begin{array}{l}\text { Atlantic salmon } \\
\text { liver (ww) }\end{array}$ & Not identified & $<7.5$ & $<8$ & $<19$ & $<19$ & $\begin{array}{l}\text { Kannan et al. } \\
(2002 a)\end{array}$ \\
\hline Fish liver (ww) & Japan & LOD - 19 & $3-7900$ & - & - & $\begin{array}{l}\text { Taniyasu et al. } \\
(2003)\end{array}$ \\
\hline $\begin{array}{l}\text { Freshwater fish } \\
(w w)\end{array}$ & $\begin{array}{l}\text { Nordic } \\
\text { countries }\end{array}$ & $<L O D-3.4$ & $4.7-551$ & $<L O D-1.4$ & $0.6-141$ & This study \\
\hline Marine fish (ww) & $\begin{array}{l}\text { Nordic } \\
\text { countries }\end{array}$ & $<L O D-0.4$ & $0.9-62$ & $<L O D-5.4$ & $\begin{array}{l}\angle L O D- \\
30\end{array}$ & This study \\
\hline
\end{tabular}

The PFAS levels found in the Nordic whale samples (e.g., minke whales, pilot whales) were considerably lower contaminated as previously reported for marine mammals (dolphin liver) from Middle America (Mexico, USA). 


\subsection{Level comparison with conventional "legacy" persistent organic pollutants}

Persistent organic pollutants (POP) have been investigated comprehenisively in all environmental contaminants throughout the past decades. Although many of the legacy POPs are banned or restivted in use on a international basis, high levels are still remaining in the environment documenting their high persistence and stability in the environment. Compounds like polychlorinated biphenyls (PCB), hexachlorocyclohexans (HCHs) and hexachlorobenzene (HCB) are still in the focus of environmental concern although banned for decades.

In order to illustrate the environmental significance of our findings in the light of the general contamination of environmental compartments with persistent organic contaminants, a first comparison with levels reported for selected conventional persistent organic pollutants (POP) from the literature is presented (table 20).

\subsubsection{Concentration comparison in Seawater}

PCBs belong to the most investigated POP compounds worldwide since they were detected for the first time in the 1960s. PFAS levels in the Nordic environmental samples analysed are in general found in comparable concentration ranges as reported for PCB. For seawater the levels found for sum PFAS was considerabley higher than the PCB values reported for the North Sea. Also compared to $\gamma-\mathrm{HCH}$ (a still in-use pesticide) and HCB, the levels for PFAS are considerably higher in North Sea water (table 20).

\subsubsection{Concentration comparison in Fresh water}

The PFAS levels in fresh water (lake Mjøsa) are also higher than reported for PCBs in Russian rivers. However $\gamma-\mathrm{HCH}$ levels in freshwater are exceeding the Sum PFAS concentration reported for the Nordic countries in average 10 times. The polycyclic musk compounds Galaxolide (HHCB) and Tonalide (AHTN) are found in even higher concentrations in fresh water systems (table 20).

\subsubsection{Concentration comparison in rain water}

The concentration levels for PFAS found in wet depostion (rain water) is found in the same concentration range than reported for $\gamma-\mathrm{HCH}$. However, hexachlorobenzene (HCB) was found in considerably higher levels than PFAS. In the newly reported ThemaNord report 503 "Synthetic musks in the Nordic environment", rain water samples were analysed for synthetic musks. Synthetic musks were found in the same concentration range as reported for PFAS.

\subsubsection{Concentration comparison in sediments}

PCBs in contaminated sediments are found in higher concentration ranges than PFAS indicating the importance of considering the different physico-chemical properties of the two compound groups for a proper environmental fate assessment. However, both $\gamma-$ $\mathrm{HCH}$ and $\mathrm{HCB}$ are generally reported in concentration ranges comparable to PFAS in Nordic sediments. Synthetic musks (HHCB and AHTN) are reported in concentrations 
exceeding PFAS levels in several orders of magnitudes (although reported on a dry weight basis). PBDE 47 (2,2',4,4'-TeBDE) is found in considerably lower concentration ranges in Swedish Sediments than found for PFAS in the Nordic samples (table 20).

\subsubsection{Concentration comparison in sewage effluent}

In landfill effluent, sum PFAS levels from the here presented Nordic study exceed sum PCB concentrations from New Jersey, USA by one order of magnitude (table 20).

\subsubsection{Concentration comparison in sewage sludge}

Also for conventional POPs, sewage sludge is always a medium where high concentrations can be expected. PCBs levels are exceeding the levels reported for PFAS. Also synthetic musks (HHCB and AHTN) are orders of magnitude higher concentrated in sewage sludge compared with PFAS (Table 21). PBDE levels (PBDE 47) were found to be in a similar concentration range in sewage sludge as reported for PFAS.

\subsubsection{Concentration comparison in landfill effluent}

In landfill effluent, PCB concentrations reported are found in a similar concentration range (New Jersey, USA) as reported for PFAS in the here presented Nordic study. However, the maximum values for PFAS are about 10 times higher then the PCB concentrations reported in US landfill effluent (waste water).

\subsubsection{Concentration comparison in marine mammals}

Marine mammals represent a very heterogeneous group of marine animals with regard to trophic levels, food and migration habits as well as physiology and adaptations to their environments. However, in order to provide first indication for compound group specific distribution, this generalisation is thought to be adequate. PFAS levels in marine mammals from Nordic countries (grey-/ harbour seals, pilot whales and minke whales) were found in similar concentration ranges as reported for PCBs, HCB and $\gamma-$ $\mathrm{HCH}$ in marine mammals from Norwegian coastal waters. The concentration reported for PBDE47 is considerably lower than the PFAS levels found (Table 20).

\subsubsection{Concentration comparison in marine fish}

Concentration ranges reported for conventional POPs in marine fish samples are varying considerably depending on sampling location and species caught. However, in general it was found that PFAS levels in the marine fish species collected during the Nordic screening exercise are lower than reported for PCBs. On the other hand, $\gamma-\mathrm{HCH}$ and PBDE47 are usually reported in lower concentrations than PFAS. HCB is found in a similar concentration range as PFAS. 


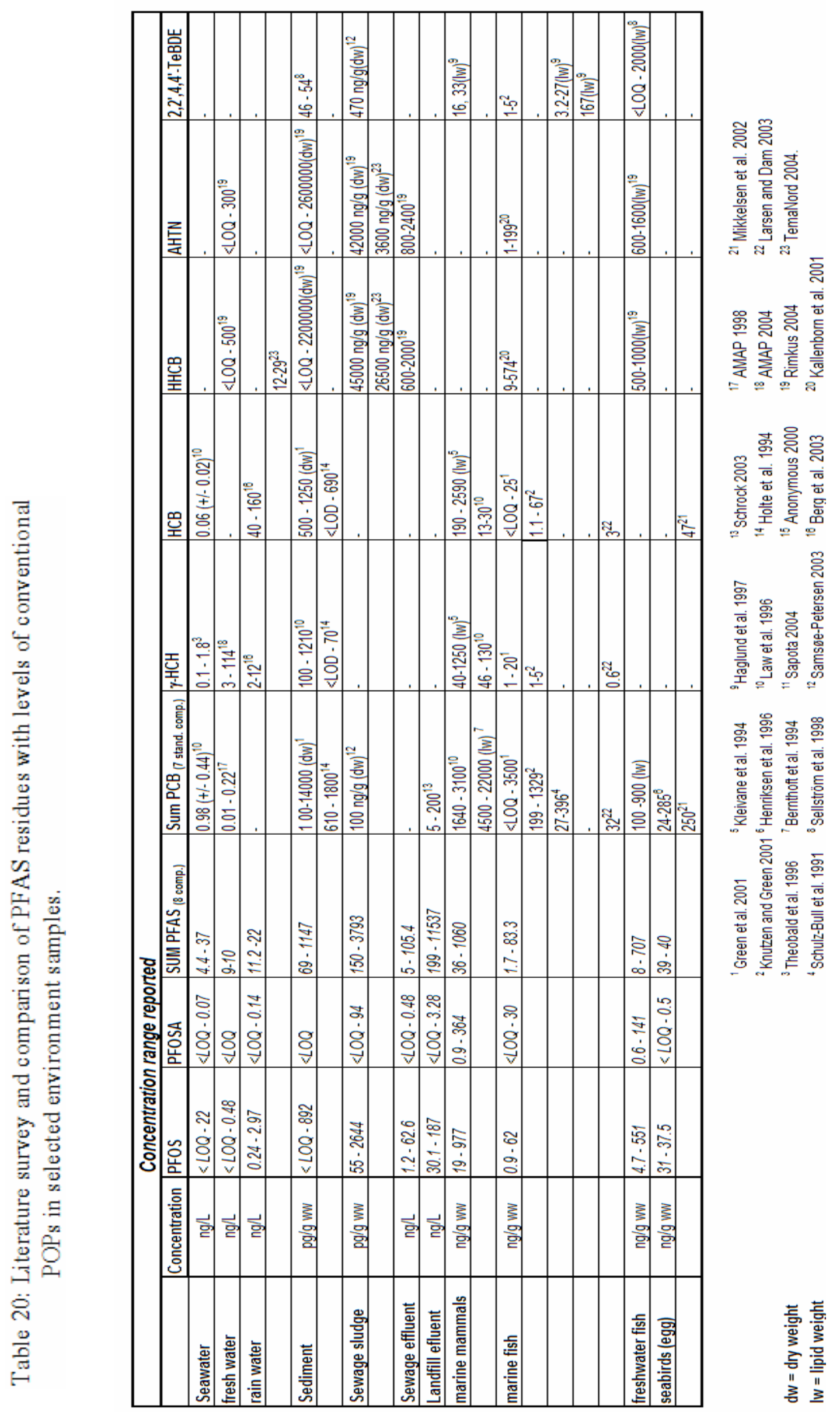




\subsubsection{Concentration comparison in fresh water fish}

PCB and PFAS levels are found in a similar concentration range. However since PCB levels are reported on a lipid weight basis $(\mathrm{lw}), \mathrm{PCBs}$ in freshwater fish might be even somewhat lower concentrated. Data from Faroe Islands Arctic char (Larsen and Dam 2003) indicate that PCB7 are in the same order of magnitude as reported for PFAS. Synthetic musks (HHCB and AHTN) and brominated flame retardants (PBDE 47) are found in considerably higher levels than reported for PFAS.

\subsubsection{Concentration comparison in seabirds}

PCB concentrations reported from glaucous gulls (Arctic) are in the same concentration range as found for PFAS in Fulmar eggs from the Faroe Islands (table 21). However PCB7 and HCB were also analysed in the Fulmar eggs used for the PFAS screening study (Mikkelsen et al. 2002). The PCB7 concentrartions exceed the PFAS levels considerably whereas HCB weas int the same concentration range as reported for PFAS (Table 20)

\subsection{Toxicity and ecotoxicity}

Today, very little is known about toxicity and ecotoxicity of PFAS related compounds. Some toxicity data exist for the already identified major environmental PFAS contaminants PFOS and PFOA (Butenhoff et al. 2004). Recently, evidence for neonatal toxicity on Sprague-Dawley rats was reported (Grasty et al. 2003, Thibodeaux et al. 2003). Even invertebrates show toxic effects when exposed to high levels of PFOS (Boudreau et al. 2003). PFOA has been identified as potent peroxisome proliferator in mice (Xie et al. 2003). Genotoxic effects in rates have been postulated for PFOA (Butenhoff et al. 2003). Strong influences on zooplankton populations upon PFOA exposure are reported recently (Sanderson et al. 2003). Hu et al. (2003) found for a comprehensive number of PFAS (incl. PFOS, PFBS, PFHxS) toxic properties leading to alterations in cell membranes. Boudreau et al (2001) reported low LC50 results for PFOA, PFOS and PFDA. There are no scientifically evaluated data reported or published neither on PHpA, PFHpS, PFDS nor on PFNA. A list of reported information on PFOS and PFOA is summarised in table 21.

Compared with the available toxicological and ecotoxicological data, all concentration values are well below the reported threshold levels (Table 20). The reported LC50 and NOEC values are all in the mg-range whereas the PFAS concentrations in the Nordic screening studie are found in the upper ng - lower $\mu \mathrm{g}$ range. However, no information about chronic exposure to low levels is available yet.

More detailed information about tosicology/Ecotoxicology of PFAS related compounds can be found in the references listed in table 21 . 


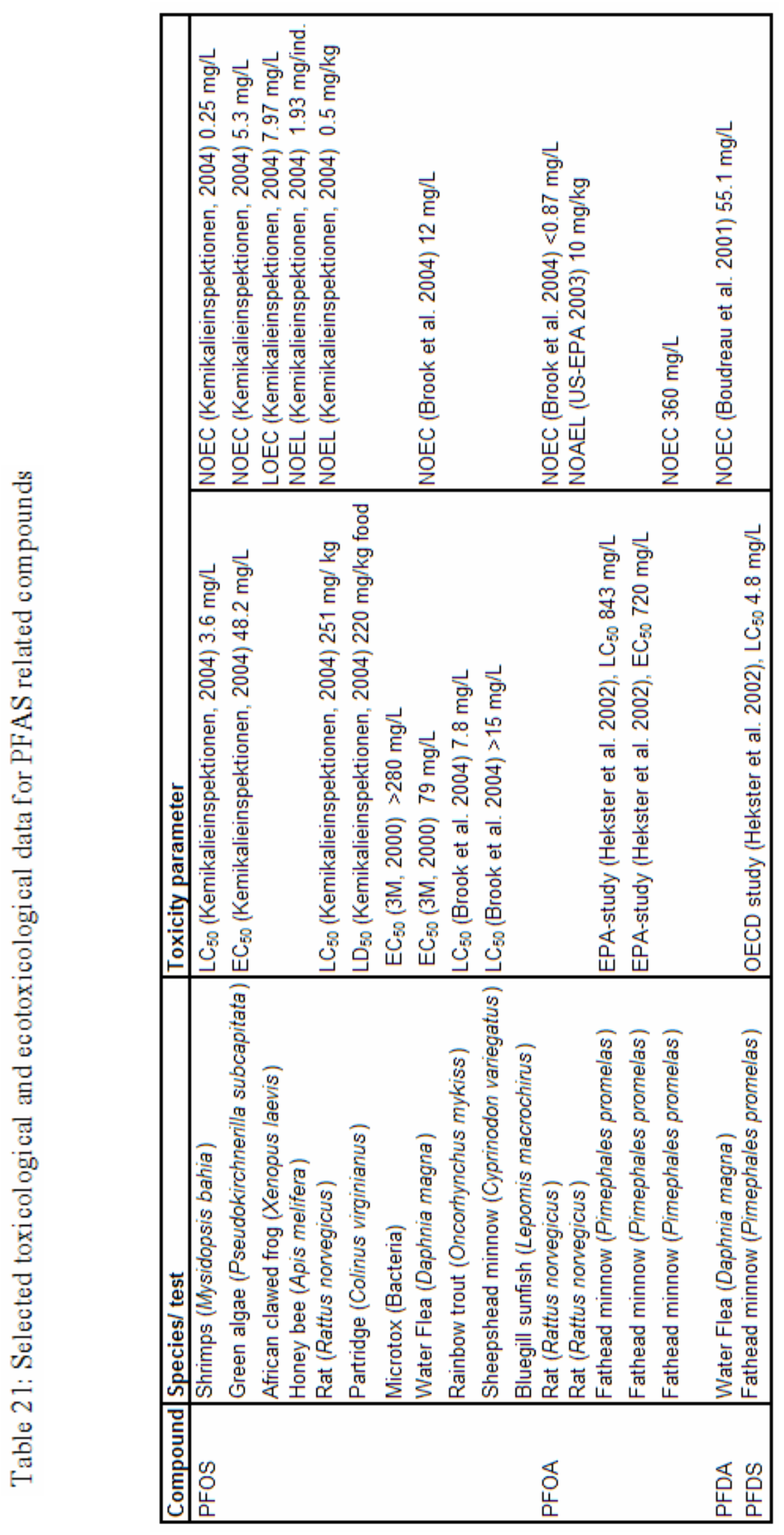




\subsection{Sources and environmental implications}

The here presented Nordic screening exercise on the fate and occurrence of PFAS related residues in the environment confirmed that landfill deposition and sewage treatment are to be considered as important sources for the release of PFAS residues into the aqueous environment (seawater and freshwater). Landfills and waste deposition sites are obviously to be considered as major sources due to the comprehensive application profile of PFAS related products (household related products, textiles, flame retardants etc.). Thus, the Nordic screening on PFAS confirms the first suspicion the waste dumps might play a major role as primary sources for PFAS residues in the environments.

However, measurable amounts of PFAS were found also in precipitation samples from Sweden and Finland demonstrating, that selected PFAS chemicals are prone to atmospheric transport and sub-sequent wet deposition via rain. Thus, selected PFAS related contaminants should be evaluated with regard to long-range transport potential.

PFOS and PFOSA dominated the PFAS burden in top predating organisms and thus indicate strong bioaccumulation tendencies. These findings support earlier reports where PFOS and PFOSA were detected in high concentrations in top predating species even from Arctic regions. PFAS related compounds like PFOS and PFOSA must therefore be evaluated as persistent and bio-accumulative residues.

These basic properties characterising many PFAS related chemicals as persistent and bioaccumulative in conjunction with recent ecotoxicological studies supports the need to add PFAS into the UNEP category of PBT compounds: "Persistent, bioaccumulative and toxic".

\subsection{Consequences and recommended actions}

The here presented report contributes to the international scientific efforts to elucidate the hazarous potential of PFAS-related contaminants in the environment. The results presented illustrate the heterogeneity of this group of contaminants with regard to physico-chemical properties, accumulation potential and ecotoxicological potential.

PFAS related contamination was detected in all samples from all participating Nordic countries. These contaminants are present in all countries and, thus, an ubiquitous distribution must be assumed not only across the Nordic countries but globally.

Compounds with considerable bioaccumulation potential like PFOS and PFOSA are found in high concentrations in top predating marine mammals like harbour and grey seals as well as in pilot whales.

As earlier described, PFAS residues are practically not biodegradable and are, thus, expected to be present in the environment for many decades to come. It is therefore recommended to include these PFAS related chemicals major environmental hazards in the national and international monitoring programs for environmental contaminants. 


\section{Conclusions and suggestions}

The here presented results from a first screening on perfluorinated alkylated substances (PFAS) is contributing to the international scientific efforts to evaluate and characterise the environmental behaviour of this very special group of environmental contaminants. A core group of 6 PFAS compounds PFOS, PFOA, PFOSA, PFHxA, PFNA, PFHxS) was analysed in all 119 samples covering seawater, rain water, fresh water, sewage sludge, sewage effluent, landfill effluent, seabird eggs (Fulmar) and liver samples from 16 species of marine and freshwater fish as well as marine mammals. As a voluntary addition to the contracted work, PFHpA (perfluoroheptanoic acid), PFBS (perfluorobutane sulfonate) and PFDS (perfluorodecane sulfonate) were analysed.

PFAS residues were found in all environmental matrices analysed. Specific matrixdependent distribution patterns were found. PFOS and PFOA were usually dominating in abiotic samples whereas PFOS and PFOSA were the predominant PFAS residues in biota. For abiotic samples, the highest PFAS levels were found in landfill effluent and sewage sludge whereas the top-predating grey seals were highest contaminated in the biota sample set.

The PFAS levels found were usually in the same order of magnitude or even higher than reported for conventional "legacy" persistent organic pollutants. In sewage samples, however, PCBs and synthetic musks were higher concentrated.

Until today, very little information is available on the ecotoxicological behaviour and effects of PFAS in biological systems. However, the concentrations found in landfill effluents and sewage are detected in concentration ranges where chronic exposure might cause adverse effects in ambient biosystems.

Based on the here presented results, PFAS compounds are identified as chemicals with considerable environmental distribution. Thus, the major contributors of this contaminant group should be implemented in on-going monitoring activities after analytical methods are adapted to this purpose. Due to their physico-chemical properties, most of the PFAS compounds are not accumulating in lipid-rich tissues. Thus, matrices bird eggs, like liver, bile and blood should be preferred for monitoring of PFAS. It is recommended to include freshwater fish located close to possible waste dumps since such locations may represent major sources for environmental distribution of PFAS. Long-range transport as a possible source should be included in futiure environmental monitoring planning. Thus, more in-depth sampling in coastal waters and remote atmosphere should give information on the long-range transport potential.

PFAS residues are virtually indestructible and, thus, will eventually reach concentrations in biota with effects on physiology and environmental health 


\section{Acknowledgements}

The support and help of many co-workers is greatly acknowledged. Without the help of numerous colleagues from the respective Nordic institutions responsible for sampling and sample handling, the project would not have been possible to realise.

\section{Sample preparation, analysis and quantification:}

Arve Bjerke (NILU) was responsible for preparation of the abiotic samples. We appreciate the help of Christian Dye (NILU) during analysis and quantification of the abiotic samples. Katrin Holmström (ITM) and Carina Johansson (ITM) assisted Ulf Järnberg (ITM) in the collecting and preparation of the biological samples.

\section{Sample collection:}

The following colleagues have been responsible for/ supported the study for the national sampling for the Nordic screening for PFAS related compounds in the environment. In addition numerous institutions/ organisation contributed with help, advise and personnel to the success of the here presented study:

\section{Norway:}

Eirik Fjeld, Norwegian Institute of Water Research (NIVA) provided water and biota samples, Trine Eggen, Norwegian Centre for Soil and Environmental Research (Jordforsk) provided landfill and sludge samples.

\section{Denmark:}

The counties of Copenhagen, Roskilde, Fyn and Ringkøbing (water, sludge mussels and fish) contributed to the sample collection.

Martin Larsen, National environmental Research Institute NERI) maintained the contact to the county officials. Jonas Theilman, (NERI) is acknowledged for providing the harbour seal liver samples.

\section{Finland:}

Sirpa Paattakainen (rainwater sampling) and Tarja Bertula from SYKE's Laboratory performed the pike sample dissection. The Uusimaa Regional Environment Centre was responsible for seawater and sediment sampling, Helsinki City provided sludge as well effluent samples and performed pike fishing. Espoo City and Porvoo City provided sludge and effluent samples and Helsinki Metropolitan Area Council was contributing with landfill effluent sampling.

\section{Iceland:}

In Iceland the following specialists helped to organise sampling of specimens and materials for the PFOS analysis: Gudjun Atli Audunsson, The Icelandic Fisheries Laboratories and Jörundur Svavarsson, Institute of Biology, University of Iceland.

\section{Faroe Islands:}

In the Faroe islands the following specialists and associations have contributed during sampling and sample handling: Katrin Hoydal and Jóhannis Danielsen (marine fish 
sampling), the Faroe Islands Angelers Association, as well as Jens-Kjeld Jensen, Poul Jóhannis Simonsen og Janus Hansen.

\section{Sweden:}

The follwoing experts have contributing to sample collection and handling: Mikael Svensson, MS Naturfakta, Osby: Abborre Helgeån Kristianstad Olle Viberg, Simrishamn: Atlantic cod (Hanöbukten), Tjelvar Odsjö and coworkers, Gruppen för miljögiftsforskning, Naturhistoriska Riksmuseet: Atlantic cod from Hoburgen (SE off Gotland): Charlotta Persson and Kristianstads municipality (STP slam). 


\section{Literature}

AMAP (1998) AMAP Assessment Report: Arctic pollution issues. Arctic Monitoring and Assessment Programme (AMAP), Oslo, Norway. XII + pp.859.

AMAP (2004) AMAP assessment 2002: Persistent Organic Pollutants in the Arctic. Arctic Monitoring and Assessment Programme (AMAP), Oslo, Norway. XVI + pp. 310.

Anonymous (1999) The science of organic fluorochemistry. 3M Report OPPT-20020043-0006: pp. 12.

Anonymous (2000) Naturmiljön i siffror 2000. Swedish Environmental Protection agency, pp. 296.

Anonymous (2002) Environmental directorate, Joint meeting of the chemicals committee and the working party on chemicals, pesticides and biotechnology. Cooperation on existing chemicals. Hazard assessment of perfluorooctane sulfonate (PFOS) and its salts. Report JT00135607; ENV/JM/RD(2002)17/FINAL: pp. 362.

Berg T., Kallenborn R., Manø S. \& Uggerud H. Th. (2003) Tidstrender i atmosfærekonsentrasjoner av tungmetaller og persistente organiske miljøgifter. Statlig Program for Forurensningsovervåking (SFT), report 883/03, pp. 24

Bernthoft A. \& Skaare J.U. (1994) Levels of selected individual polychlorinated biphenyls in different tissues of harbour seals (Phoca vitulina) from the southern coast of Norway. Environ. Poll. 86:99-107

Boudreau T.M. Janutka R., Solomon K.R., Muir D.C.G. \& Mabury S.A. (2001) Perfluorinated surfactants; Aquatic Toxicity studies on freshwater primary and secondary trophic levels. SETAC Europe conference, Madrid (Spain).

Boudreau T.M., Wilson C.J., Cheong W.J., Sibley P.K., Mabury S.A., Muir D.C.G \& Solomon K.R. (2003) Response of the zooplankton community and environmental fate of perfluorooctane sulfonic acid in aquatic microcosms. Environ. Toxicol. Chem. 22/11: 2739-2745.

Brook. D., Footitt A. \& Nwaogu T.A. (2004) Environmental risk evaluation report: Perfluorooctanesulfonate (PFOS). UK Environmental Agency, Isis House, Howbery Park, Wallingford OX10 8BD, in preparation.

Buegel-Mogensen B., Pritzl G., Rastogi S., Glesne O., Hedlund B., Hirvi J.-P., lundgren A. \& Sigurdsson A. (2004) Synthetic musks in the Nordic environment. ThemaNord 2003-503, Nordic Council of Ministers, Copenhagen 2004, ISBN 92-893-0981-4: pp.69.

Butenhoff J.L., Kennedy G.L., O'Connor J.C. \& York R.G. (2003) Multi-generation reproduction study of ammonium perfluorooctanoate in rats. Toxicologist 72/S-1: 76.

Butenhoff J.L., Gaylor D.W., Moore J.A., Olsen G.W., Rodricks J. Mandel J.H. \& Zobel L.R. (2004) Characterization of risk for general population exposure to perfluorooctanoate. Regul. Toxicol. Pharmacol. 39: 363-380. 
Cederberg I., Edell Å. \& Lindqvist I. (2004) PFOS; Rapport från en förstudie. Report, kemikalieinspektionen, pp.21.

Chow S.C. (2003) Encyclopedia of Biopharmaceutical Statistics, $2^{\text {nd }}$ Edition. Dekker, pp. 1000 , ISBN: 0-8247-4261-3.

Falandysz J., Kannan K. Tanabe S. \& Tatsukava R (1994) Organochlorine pesticides and polychlorinated biphenyls in cod-liver oils: North Atlantic, Norwegian Sea, North Sea and Baltic Sea. Ambio 23/4-5: 288-293.

Giesy J. P. \& Kannan, K. (2001) Global distribution of perfluorooctane sulfonate in wildlife. Environ. Sci. Technol. 35 : 1339-1342.

Grasty R.C., Grey B.E., Lau C.S. \& Rogers J.M. (2003) Prenatal window of susceptibility to perfluorooctane sulfonate-induced neonatal mortality in the SpragueDawley rat. Birth Defects Res. Part B Dev. Reprod. Toxicol. 68/6: 465-471.

Green N., Helland A, Hylland K., Knutzen J \& Walday M. (2001) Joint Assessment and Monitoring Programme (JAMP), Overvåking av miljøgifter i marine sedimenter og organismer $1981-1999$. Statlig Program for forurensingsovervåking. Overvåkingsrapport nr. 819/01 TA-nr. 1797/2001: pp. 191.

Knutzen J \& Green N. (2001) Joint Assessment and Monitoring Programme (JAMP), "Bakgrunnsnivåer" av miljøgifter i fisk og blåskjellbasert på datamaterialet fra 1990 1998. Statlig Program for forurensingsovervåking. Overvåkingsrapport nr. 820/01 TAnr. 1798/2001: pp. 145.

Haglund P., Zoog D.R., Buser H.-R., \& Hu J. (1997) Identification and quantification of polybrominated diphenyl ethers and methoxy-polybrominated diphenyl ethers in Baltic biota. Env. Sci. Technol. 31 : 3281-3287.

Hansen, K. J., Clemen, L. A., Ellefson, M. E. \& Johnson, H. O. (2001) Compoundspecific, quantitative characterization of organic fluorchemicals in biological matrices. Environ. Sci. Technol. 2001, 35, 766-770.

Hansen K.J., Johnson H.O., Eldridge J.S., Butenhoff J.L. \& Dick L.A. (2002) Quantitative characterization of trace Levels of PFOS and PFOA in the Tennessee River. Environ. Sci. Technol.36, 1681-1685

Hekster F.M., de Voogt P., Pijnenburg A.M.C.M.\& Laane R.W.P.M. (2002) Perfluoroalkylated substances; Aquatic environmental assessment. Rijksinstituut voor Kust en Zee, Report RIKZ/2002.043:

Henriksen E.O., Gabrielsen G.W. \& and Skaare J.U. (1996) Levels and congener pattern of polychlorinated biphenyls in kittiwakes (Rissa tridactyla), in relation to mobilization of body lipids associated with reproduction. Environ. Poll. 92/1: 27-37.

Herbert G.N., Odom M.A., Craig P.S., Dick D.L. \& Strauss S.H. (2002) Method for the determination of sub-ppm concentrations of perfluoroalkylsulfonate anions in water. J. Environ. Monit. 2002, 4, 90-95.

Hoff P.T., Van de Vijer K., Van Dongen W., Esmans E.L:, Blust R. \& DeCoen W. (2003) Perfluorocctane sulfonic acid in bib (Tripterus luscus) and plaice (Pleuronectes platessa) from the Western Scheldt and the Belgian North Sea: distribution and biochemical effects. Environ. Toxicol. Chem. (2003) 22, 608-614. 
Holte B., Næs K., Dahle S. \& Gulliksen B. (1994) Marine resipientundersøkelser ved Longyearbyen og Barentsburg, Svalbard. Bunndyrssamfunn og miljøgifter i bunnsedimenter. Akvaplan-niva rapport 412.94.402. pp. 47.

Hu W., Jones P.D., DeCoen W., King L., Fraker P., Newsted J. \& Giesy J.P. (2003) Alterations in cell membrane properties caused by perfluorinated compounds. Comp Biochem Physiol C Toxicol Pharmacol. 135/1:77-88

Kallenborn R., Gatermann, G., Nygard T., Knutzen J. \& Schlabach M. (2001) Synthetic musks in Norwegian marine fish samples collected in the vicinity of densely populated areas. Fres. Environ. Bull. 10/11: 832-842

Kannan, K., Koistinen, J., Beckmen, K., Evans, T., Garzelany, J., Hansen, K. J., Jones, P. D. \& Giesy, J. P. (2001a) Accumulation of Perfluorooctane Sulfonate in Marine Mammals. Environ. Sci. Technol. 35: 1593-1598.

Kannan, K., Hansen, S. P., Franson, C. J., Bowerman, W. W., Hansen, K. J., Jones, P. D. \& Giesy, J. P. (2001b) Perfluorooctane sulfonate in fish-eating water birds including bald eagles and albatrosses. Environ. Sci. Technol. 35, 3065-3070.

Kannan, K., Newsted, J. L., Halbrook, R. S. \& Giesy, J. P. (2002a) Perfluorooctanesulfonate and related fluorinated hydrocarbons in mink and river otters from the United States. Environ. Sci. Technol., 36: 2566-2571.

Kannan, K., Corsolini, S., Falandysz, J., Oehme, G., Focardi, S. \& Giesy, J. P. (2002b) Perfluorooctanesulfonate and Related Fluorinated Hydrocarbons in Marine Mammals, Fishes, and Birds from Coasts of the Baltic and the Mediterranean Seas. Environ. Sci. Technol. 2002, 36, 3210-3216.

Kannan K., Choi J.W., Iseki N., Senthilkumar K., Kim D.H., Masunaga S. \&bGiesy J.P. Concentrations of perfluorinated acids in livers of birds from Japan and Korea (2002c) Chemosphere 49/3: 225-231

Kannan K., Hansen K.J., Wade T.L.\& Giesy J.P. (2002d) Perfluorooctane sulfonate in oysters, Crassostrea virginica, from the Gulf of Mexico and the Chesapeake Bay, USA. Arch. Environ. Contam. Toxicol. (2002d) 42, 313-318.

Kjemikalieinspektionen (2004) PFOS-relaterade ämnen. Strategi för utfasning. Inkludert Bilag 3: riskbedömning av PFOS. Kemikalieinspeskjonen (Sweden) pp. 85.

Kleivane L., Skaare J.U., Bjørge A., de Ruiter E. \& Reijnders P.J.H. (1994) Organochlorine pesticide residue and PCBs in harbour porpoise (Phocoena phocoena) incidentally caught in Scandinavian water. Environ. Poll. 89/2: 137-146.

Lange F.T., Schmidt C.K., Metzinger M., Wenz M. \& Brauch H.-J. (2004) Determination of perfluorinated carboxylates and sulfonates from aqueous samples by HPLC-ESI-MS-MS and their occurrence in surface waters in Germany. poster presentation MOPO15/006, SETAC Europe conference, Prague

Larsen R.B. \& Dam M. (2003) In: Hoydal and Dam (Eds.) AMAP Greenlanbd and the Faroe Islands 1997 - 2001. DANCEA, Ministry of Environment. Pp. 265.

Law R.J., Stringer R.L., Allchin C.R. \& Jones B.R. (1996) Metals and organochlorines in sperm whale (Physeter macrocephalus) stranded around the North Sea during 1994/1995 winter. Marine Poll. Bull. 32/1: 72-77 
Levitt D. \& Liss A. (1986) Toxicity of perfluorinated fatty acids for human and murine B cell lines. Toxicol Appl Pharmacol. 86/1: 1-11.

Martin J.W., Smithwick M.M., Braune B.M., Hoekstra P.F., Muir D.C.G. \& Marbury S.A. (2004) Identification of long-chain perfluorinated acids in biota from the Canadian Arctic. Environ. Sci. Technol 38: 373-380.

McNaught A.D. \& Wilkinson A. (1997), IUPAC Compendium of Chemical Terminology, $2^{\text {nd }}$ Edition, Blackwell Science, 1997 [ISBN 0-86542-6848].

Moody C.A. \& Field J. (2000) Perfluorinated surfactants and the environmental implications of their use in fire-fighting foams. Environ. Sci. Technol. 34, 3864-3870.

Mikkelsen B., Hoydal K., Dam M., \& Danilesen J. (2002) Føroya Umhvørvi í Tølum,

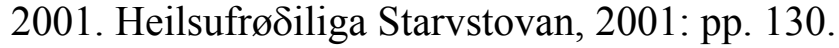

Olson C.T. \& Andersen M. E. (1983) The acute toxicity of perfluorooctanoic and perfluorodecanoic acids in male rats and effects on tissue fatty acids. Toxicol Appl Pharmacol 70(3):362-372.

Olsen G.W., Hansen K.J., Stevenson L.A., Burris J.M. \& Mandel J.H. (2003). Human donor Liver and Serum concentrations of perfluorooctanesulfate and other perfluorochemicals. Environ. Sci. Technol. 37: 888-891.

Renner R., (2001) Growing Concern over Perfluorinated Chemicals. Environ. Sci. Technol.35/7 : 154A.

Rimkus G.G. volume Ed. (2004) Synthetic musks in the Environment. In: Hutzinger O. (Editor in Chief) The Handbook of Environmental Chemistry. Springer Vlg. ISBN 3540-043706-1. pp.338.

Samsøe-Petersen L. (2003) Organic contaminants in sewage sludge. Swedish Environmental Protection agency, Report 5217. pp. 71.

Sanderson H., Boudreau T.M., Mabury S.A. \& Solomon K.R. (2003) Impact of perfluorooctanoic acid on the structure of the zooplankton community in indoor microcosms. Aquat Toxicol. 62(3):227-34.

Sapota G. (2004) Polychlorinated biphenyls (PCBs) and organochlorine pesticides (OCPs) in seawater of the southern Baltic Sea. Desalination 162: 153-157.

Schrap S.M., Voogt, de P., van Leeuwen S.P., Pijnenburg A.M.C.M..(2004) Perfluorated compounds in the Dutch aquatic environment. poster presentation MOPO15/008, SETAC Europe conference, Prague

Schrock M., Tracy K., Misita M., Tabor J., Durell G., Dahlen D., Liu B., DeGraeve M.,\& McCauley D. (2003) Wastewater contaminants measured to support the New Jersey Toxics reduction program - Part 2: dioxin, PCB and organochlorine pesticide profiles. Organohalogen Comp. 62:

Schröder H. F. (2003) Determination of fluorinated surfactants and their metabolites in sewage sludge samples by liquid chromatography with mass spectrometry and tandem mass spectrometry after pressurised liquid extraction and separation on fluorinemodified reversed-phase sorbents. J. Chrom. A (2003), 1020: 131-151

Schulz-Bull D., Petrick G \& Duinker J.C. (1991) Polychlorinated biphenyls in North Sea water. Marine Chemistry (1991) 365-384. 
Sellström U., Kierkegard A., deWit C. \& Jansson B. (1998) Polybrominated diphenyl ethers and hexabromocyclododecane in sediment and fish from a Swedish river. Environ. Toxicol. And. Chem. 17/6: 1065-1072.

Taniyasu S., Kannan K., Horii Y., Hanari N. \& Yamashita N. (2003). A survey of perfluorooctane sulfonate and related perfluorinated organic compounds in water fish, birds and humans from Japan. Environ. Sci. Technol. 37: 2634-2639.

Theobald N, Gaul H. \& Zierbarth U (1996) Verteilung von organischen Schadstoffen in der Nordsee und angrensenden Seegebieten. Deutsche Hydrographische Zeitschrift, Supplement 6.: 81-93.

Thibodeaux J., Hanson R.G., Grey B.E., Barbee B.D., Richards J.H., Butenhoff J.L., Rogers J.M. \& Lau C. (2003) Maternal and developmental toxicity of perfluorooctane sulfonate (PFOS) in the mouse. Toxicologist 2(S-1): 342

Thomsen V., Schatzlein D \& Mercuro D. (2003) Limits of detection in spectroscopy. Spectroscopy 18/12: 112-114.

U.S. Environmental Protection Agency (2000) Perfluorooctyl Sulfonates: Proposed Significant New Use Rule. Fed. Regist. 65: 62319-62333.

U.S. Environmental Protection Agency (2003) Preliminary risk assessment of the development toxicity associated with exposure to perfluorinated octanoic acid. Rreport. pp. 63.

Van de Vijer K. I., Hoff P.T., Das K., van Dongen W., Esmans E.L., Jauniaux T., Buoquegneaux J.-M., Blust R.\& deCoen W. (2003) Perfluorinated chemicals infiltrate Ocean Waters: Link between Exposure Levels and Stable Isotope Ratios in Marine Mammals. Environ. Sci. Technol. 37: 5545-5550.

Xie Y., Yang Q., Nelson B.D. \& DePierre J.W. (2003) The relationship between liver peroxisome proliferation and adipose tissue atrophy induced by peroxisome proliferator exposure and withdrawal in mice. Biochem Pharmacol. 66/5:749-756.

Ylinen,M., Hanhijarvi, H., Peura,P., \& Ramo O. (1985) Quantitative gas chromatographic determination of perfluorooctanoic acid as the benzyl ester in plasma and urine. Arch Environ Contam Toxicol, 14: 713-717

3M (2000) Sulfonated Perfluorochemicals in the Environment: Sources, Dispersion, Fate and Effects. Report pp. 51 


\section{Appendix 1: Sample characteristics}

\begin{tabular}{|c|c|c|c|c|c|c|}
\hline Sample ID & Country/ Location & Species & Sampling position & Sampling date & Sample type & Comments \\
\hline & Denmark & & & & & \\
\hline FLDAN01 & Köbenhavn Amt & Flounder & $55.44^{\circ} \mathrm{N}-12.36^{\circ} \mathrm{E}$ & & Liver & \\
\hline FLDAN02 & Köbenhavn Amt repl. & Flounder & $55.44^{\circ} \mathrm{N}-12.36^{\circ} \mathrm{E}$ & & Liver & \\
\hline FLDAN03 & Köbenhavn Amt repl. & Flounder & $55.44^{\circ} \mathrm{N}-12.36^{\circ} \mathrm{E}$ & & Liver & \\
\hline FLDAN04 & Köbenhavn Amt repl. & Flounder & $55.44^{\circ} \mathrm{N}-12.36^{\circ} \mathrm{E}$ & & Liver & \\
\hline EPDAN05 & Roskilde fjord & Eelpout & $55.44^{\circ} \mathrm{N}-12.01^{\circ} \mathrm{E}$ & & Liver & \\
\hline HEDAN06 & Roskilde fjord & Herring & 55.44 & & Liver & \\
\hline HSDAN07 & Limfjord1 & Harbour seal & $56.40^{\circ} \mathrm{N}-08.20^{\circ} \mathrm{E}$ & & Liver & \\
\hline HSDAN08 & Limfjord2 & Harbour seal & $56.40^{\circ} \mathrm{N}-08.20^{\circ} \mathrm{E}$ & & Liver & \\
\hline HSDAN09 & Hesselö & Harbour seal & $56.10^{\circ} \mathrm{N}-11.40^{\circ} \mathrm{E}$ & & Liver & \\
\hline HSDAN10 & Samsö & Harbour seal & $55.50^{\circ} \mathrm{N}-10.30^{\circ} \mathrm{E}$ & & Liver & \\
\hline \multirow[t]{2}{*}{ HSDAN11 } & Öresund & Harbour seal & $55.35^{\circ} \mathrm{N}-12.50^{\circ} \mathrm{E}$ & & Liver & \\
\hline & Finland & & & & & \\
\hline PIFIN01 & Helsinki City coast & Pike & $60.11^{\circ} \mathrm{N}-24.59^{\circ} \mathrm{E}$ & & Liver & \\
\hline
\end{tabular}




\begin{tabular}{|c|c|c|c|c|c|c|}
\hline Sample ID & Country/ Location & Species & Sampling position & Sampling date & Sample type & Comments \\
\hline PIFIN02 & Helsinki City coast & Pike & $60.11^{\circ} \mathrm{N}-24.59^{\circ} \mathrm{E}$ & 2003 & Liver & $\begin{array}{l}\text { Vanhankaupungin lahti; } \\
\text { Gammelstadsfjärden }\end{array}$ \\
\hline PIFIN03 & Helsinki City coast & Pike & $60.11^{\circ} \mathrm{N}-24.59^{\circ} \mathrm{E}$ & 2003 & Liver & $\begin{array}{l}\text { Vanhankaupungin lahti; } \\
\text { Gammelstadsfjärden }\end{array}$ \\
\hline PIFIN04 & Helsinki City coast & Pike & $60.11^{\circ} \mathrm{N}-24.59^{\circ} \mathrm{E}$ & 2003 & Liver & $\begin{array}{l}\text { Vanhankaupungin lahti; } \\
\text { Gammelstadsfjärden }\end{array}$ \\
\hline PIFIN05 & Helsinki City coast & Pike & $60^{\circ} 11^{\prime} \mathrm{N}-24^{\circ} 59^{\prime} \mathrm{E}$ & 2003 & Liver & $\begin{array}{l}\text { Vanhankaupungin lahti; } \\
\text { Gammelstadsfjärden }\end{array}$ \\
\hline PIFIN06 & Helsinki City coast & Pike & $60^{\circ} 11^{\prime} \mathrm{N}-24^{\circ} 59^{\prime} \mathrm{E}$ & 2003 & Liver & $\begin{array}{l}\text { Vanhankaupungin lahti; } \\
\text { Gammelstadsfjärden }\end{array}$ \\
\hline PIFIN07 & Helsinki City coast & Pike & $60^{\circ} 11^{\prime} \mathrm{N}-24^{\circ} 59^{\prime} \mathrm{E}$ & 2003 & Liver & $\begin{array}{l}\text { Vanhankaupungin lahti; } \\
\text { Gammelstadsfjärden }\end{array}$ \\
\hline PIFIN08 & Helsinki City coast & Pike & $60^{\circ} 11^{\prime} \mathrm{N}-24^{\circ} 59^{\prime} \mathrm{E}$ & 2003 & Liver & $\begin{array}{l}\text { Vanhankaupungin lahti; } \\
\text { Gammelstadsfjärden }\end{array}$ \\
\hline & Faroe Islands & & & & & \\
\hline SCFAR01 & Kaldbak & Sculpin & $62.03 \mathrm{~N}-06.49^{\circ} \mathrm{W}$ & May 2002 & Liver & \\
\hline SCFAR02 & Kaldbak & Sculpin & $62.03 \mathrm{~N}-06.49^{\circ} \mathrm{W}$ & May 2002 & Liver & \\
\hline DAFAR03 & Kaldbak & Dab & $62.03 \mathrm{~N}-06.49^{\circ} \mathrm{W}$ & July 2002 & Liver & \\
\hline DAFAR04 & Kirkjubö & Dab & $61.57^{\circ} \mathrm{N}-06.47^{\circ} \mathrm{W}$ & July 2002 & Liver & \\
\hline COFAR05 & Torshavn & Cod & $62.00^{\circ} \mathrm{N}-06.46^{\circ} \mathrm{W}$ & June 2002 & Liver & \\
\hline ACFAR06a & á Mýranar, Bleiki I & Arctic char & $62.10^{\circ} \mathrm{N}-07.05^{\circ} \mathrm{W}$ & July 2002 & Liver & Landlocked \\
\hline ACFAR06b & á Mýranar , Bleiki I & Arctic char & $62.10^{\circ} \mathrm{N}-07.05^{\circ} \mathrm{W}$ & July 2002 & Liver & Landlocked \\
\hline ACFAR07 & á Mýranar, Bleiki II & Arctic char & $62.10^{\circ} \mathrm{N}-07.05^{\circ} \mathrm{W}$ & July 2002 & Liver & Landlocked \\
\hline PWFAR09 & Sandagerdi & Pilot whale & $62.00^{\circ} \mathrm{N}-06.46^{\circ} \mathrm{W}$ & September 2002 & Liver & \\
\hline
\end{tabular}




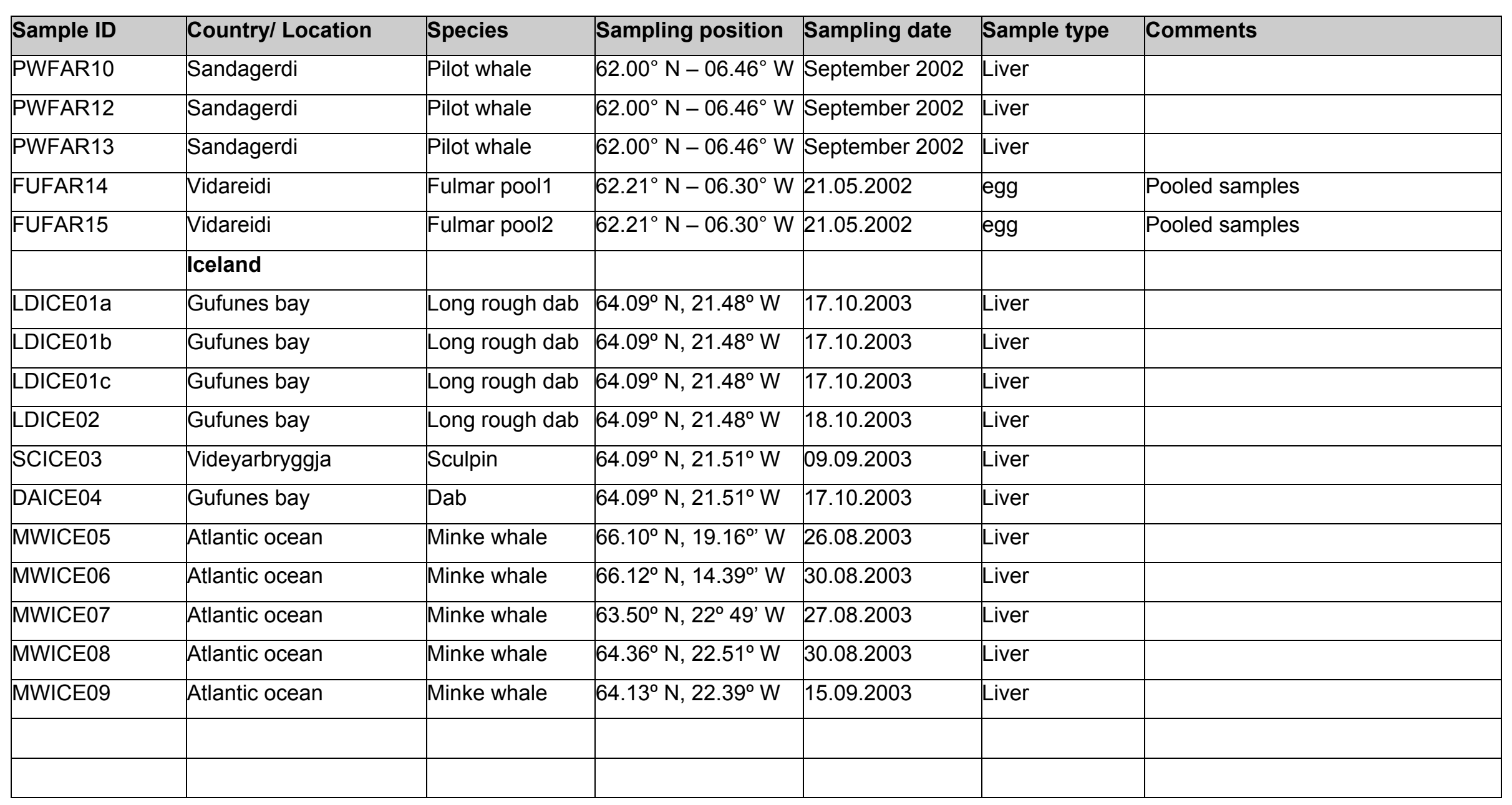




\begin{tabular}{|c|c|c|c|c|c|c|}
\hline Sample ID & Country/ Location & Species & Sampling position & Sampling date & Sample type & Comments \\
\hline & Norway & & & & & \\
\hline BUNOR01 & Mjösa: North of Gjøvik & Burbot & $60.82^{\circ} \mathrm{N}-10.67^{\circ} \mathrm{E}$ & Juni 2003 & Liver & \\
\hline TRNOR02 & Mjösa, central basin & Trout & $60.72^{\circ} \mathrm{N}-10.96^{\circ} \mathrm{E}$ & Juni-August 2003 & Liver & Pooled samples \\
\hline PINOR03 & Mjösa, North of Gjøvik & Pike & $60.82^{\circ} \mathrm{N}-10.67^{\circ} \mathrm{E}$ & Mai-June 2003 & Liver & Pooled samples \\
\hline \multirow{2}{*}{ PENOR04 } & Mjøsa, North of Gjøvik & Perch & $60.82^{\circ} \mathrm{N}-10.67^{\circ} \mathrm{E}$ & 15.06 .2003 & Liver & \\
\hline & Sweden & & & & & \\
\hline PESWE01 & $\begin{array}{l}\text { Helgeån } \\
\text { Gummastorpasjäön }\end{array}$ & Perch & $56.00^{\circ} \mathrm{N}-12.10^{\circ} \mathrm{E}$ & & Liver & \\
\hline PESWE02 & Helgeån Araslövssjön & Perch & $62.15^{\circ} \mathrm{N}-13.95^{\circ} \mathrm{E}$ & & Liver & \\
\hline PESWE03a & $\begin{array}{l}\text { Helgeån Hammarsjön Ö } \\
\text { repl. }\end{array}$ & Perch & $62.10^{\circ} \mathrm{N}-13.99^{\circ} \mathrm{E}$ & & Liver & \\
\hline PESWE03b & $\begin{array}{l}\text { Helgeån Hammarsjön Ö } \\
\text { repl. }\end{array}$ & Perch & $62.10^{\circ} \mathrm{N}-13.99^{\circ} \mathrm{E}$ & & Liver & \\
\hline PESWE04 & Helgeån Hammarsjön N & Perch & $62.08^{\circ} \mathrm{N}-14.05^{\circ} \mathrm{E}$ & & Liver & \\
\hline COSWE05 & Hoburgen & Cod & $56.54^{\circ} \mathrm{N}-18.10^{\circ} \mathrm{E}$ & & Liver & \\
\hline COSWE06 & Hoburgen & Cod & $56.54^{\circ} \mathrm{N}-18.10^{\circ} \mathrm{E}$ & & Liver & \\
\hline COSWE07 & Hoburgen & Cod & $56.54^{\circ} \mathrm{N}-18.10^{\circ} \mathrm{E}$ & & Liver & \\
\hline COSWE08 & Hoburgen & Cod & $56.54^{\circ} \mathrm{N}-18.10^{\circ} \mathrm{E}$ & & Liver & \\
\hline COSWE09 & Hoburgen & Cod & $56.54^{\circ} \mathrm{N}-18.10^{\circ} \mathrm{E}$ & & Liver & \\
\hline COSWE10 & Hoburgen & Cod & $56.54^{\circ} \mathrm{N}-18.10^{\circ} \mathrm{E}$ & & Liver & \\
\hline
\end{tabular}




\begin{tabular}{|l|l|l|l|l|l|l|}
\hline Sample ID & Country/ Location & Species & Sampling position & Sampling date & Sample type & Comments \\
\hline COSWE11 & Hanöbukten & Cod & $55.41^{\circ} \mathrm{N}-14.21^{\circ} \mathrm{E}$ & Liver & \\
\hline COSWE12 & Hanöbukten & Cod & $55.41^{\circ} \mathrm{N}-14.21^{\circ} \mathrm{E}$ & Liver & \\
\hline GSSWE13 & Sörmland & Grey seal & $58.50^{\circ} \mathrm{N}-18.00^{\circ} \mathrm{E}$ & Liver & \\
\hline GSSWE14 & Uppland & Grey seal & $60.30^{\circ} \mathrm{N}-18.20^{\circ} \mathrm{E}$ & Liver & \\
\hline GSSWE15 & Gästrilkand & Grey seal & $61.00^{\circ} \mathrm{N}-17.50^{\circ} \mathrm{E}$ & Liver & \\
\hline
\end{tabular}


Seawater, freshwater, Sediment and sludge samples

\begin{tabular}{|c|c|c|c|c|c|c|}
\hline Sample type & Sample ID & $\begin{array}{l}\text { Sampling } \\
\text { location }\end{array}$ & Sample amount analysed & Sampling date/ time & Additional information & $\begin{array}{l}\text { Position: Lat. - } \\
\text { Long. }\end{array}$ \\
\hline Sea water & SWFIN01 & Helsinki & $497 \mathrm{~g}$ & $21.08 .2003,10.00 \mathrm{~h}$ & $\begin{array}{l}\text { Brackish sea water, main } \\
\text { city area }\end{array}$ & $60.11^{\circ} \mathrm{N}^{\prime}-24.59^{\circ} \mathrm{E}$ \\
\hline Sea water & SWFIN02 & Helsinki & $517 \mathrm{~g}$ & $21.08 .2003,13.00 \mathrm{~h}$ & Outside Helsinki & $60.06^{\circ} \mathrm{N}-24.45^{\circ} \mathrm{E}$ \\
\hline Sea water & SWFIN03 & Porvoo & $490 \mathrm{~g}$ & $19.08 .2003,11.00 \mathrm{~h}$ & Brackish sea water & $60.44^{\circ} \mathrm{N}-25.33^{\circ} \mathrm{E}$ \\
\hline Sea water & SWFIN04 & Porvoo & $503 \mathrm{~g}$ & $19.08 .2003,13.00 \mathrm{~h}$ & Brackish sea water & $60.15^{\circ} \mathrm{N}-25.32^{\circ} \mathrm{E}$ \\
\hline Rain water & RWFIN05 & Helsinki & $492 g$ & 23.-27.08.2003 & Urban + industrial influences & $60.27^{\circ} \mathrm{N}-24.87^{\circ} \mathrm{E}$ \\
\hline Rain water & RWFIN06 & Helsinki & $490 \mathrm{~g}$ & 21.-22.08.2003 & Urban + industrial influences & $60.27^{\circ} \mathrm{N}-24.87^{\circ} \mathrm{E}$ \\
\hline $\begin{array}{l}\text { Landfill effluent water } \\
\text { (sub-samples) }\end{array}$ & LFFIN07a & Espoo & $492 \mathrm{~g}$ & 02.09 .2003 & untreated effluent water & $60.12^{\circ} \mathrm{N}-24.32^{\circ} \mathrm{E}$ \\
\hline $\begin{array}{l}\text { Landfill effluent water } \\
\text { (sub-samples) }\end{array}$ & LFFIN07b & Espoo & $496 \mathrm{~g}$ & 02.09 .2003 & untreated effluent water & $60.12^{\circ} \mathrm{N}-24.32^{\circ} \mathrm{E}$ \\
\hline $\begin{array}{l}\text { Landfill effluent water } \\
\text { (sub-samples) }\end{array}$ & LFFIN07c & Espoo & $497 \mathrm{~g}$ & 02.09 .2003 & untreated effluent water & $60.12^{\circ} \mathrm{N}-24.32^{\circ} \mathrm{E}$ \\
\hline Sewage effluent water & SEFIN08 & Helsinki & $504 g$ & 29.08 .2003 & Urban + industrial influences & $60.27^{\circ} \mathrm{N}-24.87^{\circ} \mathrm{E}$ \\
\hline $\begin{array}{l}\text { Sewage effluent water } \\
\text { (sub-samples) }\end{array}$ & SEFIN09a & Porvoo & $513 g$ & 29.08 .2002 & Urban + industrial influences & $60.37^{\circ} \mathrm{N}-25.61^{\circ} \mathrm{E}^{\prime}$ \\
\hline $\begin{array}{l}\text { Sewage effluent water } \\
\text { (sub-samples) }\end{array}$ & SEFIN09b & Porvoo & $510 \mathrm{~g}$ & 29.08 .2003 & Urban + industrial influences & $60.37^{\circ} \mathrm{N}-25.61^{\circ} \mathrm{E}^{\prime}$ \\
\hline Sediment (sub-samples) & SDFIN10a & Helsinki & $4.8 \mathrm{~g}$ & 21.08 .2003 & Site 1 & $60.06^{\circ} \mathrm{N}-24.45^{\circ} \mathrm{E}$ \\
\hline
\end{tabular}




\begin{tabular}{|c|c|c|c|c|c|c|}
\hline Sample type & Sample ID & $\begin{array}{l}\text { Sampling } \\
\text { location }\end{array}$ & Sample amount analysed & Sampling date/ time & Additional information & $\begin{array}{l}\text { Position: Lat. - } \\
\text { Long. }\end{array}$ \\
\hline Sediment (sub-samples) & SDFIN10b & Helsinki & $5.0 \mathrm{~g}$ & 21.08 .2003 & Site 1 & $60^{\circ} 06^{\prime} \mathrm{N}-24^{\circ} 45^{\prime} \mathrm{E}$ \\
\hline Sediment (sub-samples) & SDFIN10c & Helsinki & $5.0 \mathrm{~g}$ & 21.08 .2003 & Site 1 & $60^{\circ} 06^{\prime} \mathrm{N}-24^{\circ} 45^{\prime} \mathrm{E}$ \\
\hline Sediment & SDFIN11 & Porvoo & $1.6 \mathrm{~g}$ & 19.08.2003, $11.00 \mathrm{~h}$ & Site 2 & $60.14^{\circ} \mathrm{N}-25.33^{\circ} \mathrm{E}$ \\
\hline Sediment & SDFIN12 & Porvoo & $2.1 \mathrm{~g}$ & 19.08.2003, $13.00 \mathrm{~h}$ & Site 1 & $60.15^{\circ} \mathrm{N}-25.32^{\circ} \mathrm{E}$ \\
\hline Sewage sludge & SSFIN13 & Espoo & $5.2 \mathrm{~g}$ & 01.09 .2003 & dewatered & $60.11^{\circ} \mathrm{N}-24.74^{\circ} \mathrm{E}$ \\
\hline $\begin{array}{l}\text { Sewage sludge (sub- } \\
\text { samples) }\end{array}$ & SSFIN14a & Helsinki & $5.3 \mathrm{~g}$ & 29.08 .2003 & dewatered & $60.27^{\circ} \mathrm{N}-24.87^{\circ} \mathrm{E}$ \\
\hline $\begin{array}{l}\text { Sewage sludge (sub- } \\
\text { samples) }\end{array}$ & SSFIN14b & Helsinki & $5.0 \mathrm{~g}$ & 29.08 .2003 & dewatered & $60.27^{\circ} \mathrm{N}-24.87^{\circ} \mathrm{E}$ \\
\hline $\begin{array}{l}\text { Sewage sludge (sub- } \\
\text { samples) }\end{array}$ & SSFIN14c & Helsinki & $5.0 \mathrm{~g}$ & 29.08 .2003 & dewatered & $60.27^{\circ} \mathrm{N}-24.87^{\circ} \mathrm{E}$ \\
\hline Sewage sludge & SSFIN15 & Porvoo & $4.8 \mathrm{~g}$ & 28.08 .2003 & dewatered & $60.37^{\circ} \mathrm{N}-25.61^{\circ} \mathrm{E}$ \\
\hline Sewage sludge & SSFIN16 & Porvoo & $4.3 g$ & 19.08 .2003 & dewatered & $60.37^{\circ} \mathrm{N}-25.61^{\circ} \mathrm{E}$ \\
\hline Rainwater (sub-samples) & RWSWE01a & Råö & $496 \mathrm{~g}$ & $\begin{array}{l}02.10 .2003- \\
11.11 .2003\end{array}$ & & $57.39^{\circ} \mathrm{N}-11.91^{\circ} \mathrm{E}$ \\
\hline Rainwater (sub-samples) & RWSWE01b & Råö & $511 \mathrm{~g}$ & $\begin{array}{l}02.10 .2003- \\
11.11 .2003\end{array}$ & & $57.39^{\circ} \mathrm{N}-11.91^{\circ} \mathrm{E}$ \\
\hline Rainwater & RWSWE02 & Råö & $519 g$ & $\begin{array}{l}11.11 .2003- \\
03.12 .2003\end{array}$ & & $57.39^{\circ} \mathrm{N}-11.91^{\circ} \mathrm{E}$ \\
\hline Rainwater & RWSWE03 & Råö & $515 \mathrm{~g}$ & $\begin{array}{l}03.12 .2003- \\
15.12 .2003\end{array}$ & & $57.39^{\circ} \mathrm{N}-11.91^{\circ} \mathrm{E}$ \\
\hline Sediment & SDSWE04 & $\begin{array}{l}\text { Kristianstad, } \\
\text { Arnslövssjön }\end{array}$ & $5.2 \mathrm{~g}$ & 23.09 .2003 & Accumulation site & $62.15^{\circ} \mathrm{N}-13.95^{\circ} \mathrm{E}$ \\
\hline & & & & & & \\
\hline
\end{tabular}




\begin{tabular}{|c|c|c|c|c|c|c|}
\hline Sample type & Sample ID & $\begin{array}{l}\text { Sampling } \\
\text { location }\end{array}$ & Sample amount analysed & Sampling date/ time & Additional information & $\begin{array}{l}\text { Position: Lat. - } \\
\text { Long. }\end{array}$ \\
\hline Sediment & SDSWE05 & $\begin{array}{l}\text { Kristianstad, } \\
\text { Hammarsjön II }\end{array}$ & $4.0 \mathrm{~g}$ & 23.09 .2003 & Accumulation site & $56.00^{\circ} \mathrm{N}-14.15^{\circ} \mathrm{E}$ \\
\hline Sediment & SDSWE06 & $\begin{array}{l}\text { Kristianstad, } \\
\text { Hammarsjön I }\end{array}$ & $4.5 \mathrm{~g}$ & 23.09.2003 & Accumulation site & $56.00^{\circ} \mathrm{N}-14.15^{\circ} \mathrm{E}$ \\
\hline Sewage sludge & SSSWE07 & $\begin{array}{l}\text { Kristianstad, } \\
\text { Centrala ARV }\end{array}$ & $4.5 \mathrm{~g}$ & week 39, 2003 & $\begin{array}{l}\text { collected over the entire } \\
\text { week }\end{array}$ & $56.00^{\circ} \mathrm{N}-14.15^{\circ} \mathrm{E}$ \\
\hline Sewage sludge & SSSWE08 & Köpinge ARV & $3.0 \mathrm{~g}$ & week 39, 2003 & $\begin{array}{l}\text { collected over the entire } \\
\text { week }\end{array}$ & $55.55^{\circ} \mathrm{N}-14.15^{\circ} \mathrm{E}$ \\
\hline Sewage sludge & SSSWE09 & Tollarp ARV & $3.7 \mathrm{~g}$ & week 39, 2003 & $\begin{array}{l}\text { collected over the entire } \\
\text { week }\end{array}$ & $55.55^{\circ} \mathrm{N}-14.00^{\circ} \mathrm{E}$ \\
\hline Lake water & LWNOR01 & Lillehammer & $504 \mathrm{~g}$ & 01.07 .2003 & Lake Mjøsa & $61.09^{\circ} \mathrm{N}-10.45^{\circ} \mathrm{E}$ \\
\hline Lake water & LWNOR02 & Gjøvik & $501 \mathrm{~g}$ & 01.07 .2003 & Lake Mjøsa & $61.78^{\circ} \mathrm{N}-10.71^{\circ} \mathrm{E}$ \\
\hline Lake water & LWNOR03 & Furnesfjorden & $501 \mathrm{~g}$ & 01.07 .2003 & Lake Mjøsa & $61.87^{\circ} \mathrm{N}-10.93^{\circ} \mathrm{E}$ \\
\hline Lake water & LWNOR04a & Hamar & $515 g$ & 01.07 .2003 & Lake Mjøsa & $61.78^{\circ} \mathrm{N}-11.06^{\circ} \mathrm{E}$ \\
\hline Lake water & LWNOR04b & Hamar & $526 \mathrm{~g}$ & 01.07 .2003 & Lake Mjøsa & $61.78^{\circ} \mathrm{N}-11.06^{\circ} \mathrm{E}$ \\
\hline Landfill effluent & LFNOR05a & Spillhaug & $481 \mathrm{~g}$ & 29.09.2003, $06.45 \mathrm{~h}$ & & $59.83^{\circ} \mathrm{N}-10.85^{\circ} \mathrm{E}$ \\
\hline Landfill effluent & LFNOR05b & Spillhaug & $479 g$ & 29.09.2003, 06.45 h & & $59.83^{\circ} \mathrm{N}-10.85^{\circ} \mathrm{E}$ \\
\hline Landfill effluent & LFNOR06 & Støleheia & $483 \mathrm{~g}$ & 26.09 .2003 & $\begin{array}{l}\text { Effluent from komposting } \\
\text { treatment }\end{array}$ & $58.25^{\circ} \mathrm{N}-07.90^{\circ} \mathrm{E}$ \\
\hline Landfill effluent & LFNOR07 & Gålås & $528 \mathrm{~g}$ & $02 / 07 / 2003$ & & $59.92^{\circ} \mathrm{N}-11.60^{\circ} \mathrm{E}$ \\
\hline Landfill effluent & LFNOR08 & Røyken & $499 g$ & $27 / 08 / 2003$ & Coarse waste & $59.70^{\circ} \mathrm{N}-10.47^{\circ} \mathrm{E}$ \\
\hline Landfill effluent & LFNOR09 & Spillhaug & $497 g$ & $18 / 09 / 2003$ & effluent from cleaning plant & $59.83^{\circ} \mathrm{N}-10.85^{\circ} \mathrm{E}$ \\
\hline Sewage effluent & SENOR10 & Lillehammer & $521 \mathrm{~g}$ & 01.07 .2003 & at lake Mjøsa & $61.09^{\circ} \mathrm{N}-10.45^{\circ} \mathrm{E}$ \\
\hline
\end{tabular}




\begin{tabular}{|c|c|c|c|c|c|c|}
\hline Sample type & Sample ID & $\begin{array}{l}\text { Sampling } \\
\text { location }\end{array}$ & Sample amount analysed & Sampling date/ time & Additional information & $\begin{array}{l}\text { Position: Lat. - } \\
\text { Long. }\end{array}$ \\
\hline Sewage effluent & SENOR11a & Gjøvik & $482 \mathrm{~g}$ & 01.07 .2003 & purified outlet & $61.78^{\circ} \mathrm{N}-10.71^{\circ} \mathrm{E}$ \\
\hline Sewage effluent & SENOR11b & Gjøvik & $503 g$ & 01.07 .2003 & purified outlet & $61.78^{\circ} \mathrm{N}-10.71^{\circ} \mathrm{E}$ \\
\hline Sediment & SDNOR12 & Furnes & $5.5 \mathrm{~g}$ & 02.09 .2003 & Lake Mjøsa & $60.86^{\circ} \mathrm{N}-10.92^{\circ} \mathrm{E}$ \\
\hline Sediment & SDNOR13 & Hamar & $5.5 \mathrm{~g}$ & 01.09 .2003 & Lake Mjøsa & $60.78^{\circ} \mathrm{N}-11.06^{\circ} \mathrm{E}$ \\
\hline Sediment & SDNOR14 & Gålås & $3.5 \mathrm{~g}$ & 02.07 .2003 & Lake Mjøsa & $60.78^{\circ} \mathrm{N}-10.71^{\circ} \mathrm{E}$ \\
\hline Sewage sludge & SSNOR15 & Gjøvik & $4.9 \mathrm{~g}$ & week 36, 2003 & $\begin{array}{l}\text { collected over the entire } \\
\text { week }\end{array}$ & $60.78^{\circ} \mathrm{N}-10.71^{\circ} \mathrm{E}$ \\
\hline Sewage sludge & SSNOR16 & Lillehammer & $5.1 \mathrm{~g}$ & week 36, 2003 & $\begin{array}{l}\text { collected over the entire } \\
\text { week }\end{array}$ & $61.09^{\circ} \mathrm{N}-10.45^{\circ} \mathrm{E}$ \\
\hline Sea water & SWDAN01 & $\begin{array}{l}\text { Limfjorden } \\
\text { (Ringkøpingamt) }\end{array}$ & $512 \mathrm{~g}$ & 12.11.2003 & & $56.34^{\circ} \mathrm{N}-08.29^{\circ} \mathrm{E}$ \\
\hline Sea water (sub-samples) & SWDAN02a & Odensefjord & $503 g$ & 24.10 .2003 & S1: Seden strand & $55.26^{\circ} \mathrm{N}-10.25^{\circ} \mathrm{E}$ \\
\hline Sea water (sub-samples) & SWDAN02b & Odensefjord & $497 g$ & 24.10 .2003 & & $55.26^{\circ} \mathrm{N}-10.25^{\circ} \mathrm{E}$ \\
\hline Sea water & SWDAN03 & Roskilde & $494 \mathrm{~g}$ & 30.10 .2003 & Station 60 & $55.26^{\circ} \mathrm{N}-12.04^{\circ} \mathrm{E}$ \\
\hline Sewage & SSDAN04 & $\begin{array}{l}\text { Bjergmarken, } \\
\text { Roskilde }\end{array}$ & $4.9 \mathrm{~g}$ & 09.12 .2003 & & $55.41^{\circ} \mathrm{N}-11.51^{\circ} \mathrm{E}$ \\
\hline Sewage & SSDAN05 & Fyns amt & $5.2 \mathrm{~g}$ & 24.10 .2003 & & $55.26^{\circ} \mathrm{N}-10.25^{\circ} \mathrm{E}$ \\
\hline Sewage & SSDAN06 & $\begin{array}{l}\text { Lynetten } \\
\text { (Copenhagen) }\end{array}$ & $4.8 \mathrm{~g}$ & 28.10 .2003 & & $55.41^{\circ} \mathrm{N}-12.38^{\circ} \mathrm{E}$ \\
\hline Sea water (sub-samples) & SWICE01a & Gufunes bay & $501 \mathrm{~g}$ & 17.10 .2003 & & $64.08^{\circ} \mathrm{N}-21.49^{\circ} \mathrm{W}$ \\
\hline Sea water (sub-samples) & SWICE01b & Gufunes bay & $524 \mathrm{~g}$ & 17.10 .2003 & & $64.08^{\circ} \mathrm{N}-21.49^{\circ} \mathrm{W}$ \\
\hline
\end{tabular}




\begin{tabular}{|c|c|c|c|c|c|c|}
\hline Sample type & Sample ID & $\begin{array}{l}\text { Sampling } \\
\text { location }\end{array}$ & Sample amount analysed & Sampling date/ time & Additional information & $\begin{array}{l}\text { Position: Lat. - } \\
\text { Long. }\end{array}$ \\
\hline Sea water (sub-samples) & SWICE01C & Gufunes bay & $484 \mathrm{~g}$ & 17.10 .2003 & & $64.08^{\circ} \mathrm{N}-21.49^{\circ} \mathrm{W}$ \\
\hline Sea water (sub-samples) & SWICE01d & Gufunes bay & $517 \mathrm{~g}$ & 17.10 .2003 & & $64.08^{\circ} \mathrm{N}-21.49^{\circ} \mathrm{W}$ \\
\hline Sediment (sub-samples) & SDICE02a & Gufunes bay & $5.3 g$ & 17.10 .2004 & & $64.08^{\circ} \mathrm{N}-21.49^{\circ} \mathrm{W}$ \\
\hline Sediment (sub-samples) & SDICE02b & Gufunes bay & $5.1 \mathrm{~g}$ & 17.10 .2005 & & $64.08^{\circ} \mathrm{N}-21.49^{\circ} \mathrm{W}$ \\
\hline Sediment (sub-samples) & SDICE02c & Gufunes bay & $5.4 \mathrm{~g}$ & 17.10 .2006 & & $64.08^{\circ} \mathrm{N}-21.49^{\circ} \mathrm{W}$ \\
\hline Sediment (sub-samples) & SDICE02d & Gufunes bay & $5.0 \mathrm{~g}$ & 17.10 .2007 & & $64.08^{\circ} \mathrm{N}-21.49^{\circ} \mathrm{W}$ \\
\hline Sediment (sub-samples) & SDICE02e & Gufunes bay & $4.9 \mathrm{~g}$ & 17.10 .2008 & & $64.08^{\circ} \mathrm{N}-21.49^{\circ} \mathrm{W}$ \\
\hline Sewage (sub-samples) & SSICE03a & Klettagardar & $4.5 \mathrm{~g}$ & 16.09.2003, $10.00 \mathrm{~h}$ & & $64.09^{\circ} \mathrm{N}-21.51^{\circ} \mathrm{W}$ \\
\hline Sewage (sub-samples) & SSICE03b & Klettagardar & $5.6 \mathrm{~g}$ & $16.09 .2003,10.00 \mathrm{~h}$ & & $64.09^{\circ} \mathrm{N}-21.51^{\circ} \mathrm{W}$ \\
\hline Sewage (sub-samples) & SSICE04a & Ananaust & $5.1 \mathrm{~g}$ & 16.09.2003, $10.15 \mathrm{~h}$ & & $64.09^{\circ} \mathrm{N}-21.56^{\circ} \mathrm{W}$ \\
\hline Sewage (sub-samples) & SSICE04b & Ananaust & $4.8 \mathrm{~g}$ & 16.09.2003, $10.15 \mathrm{~h}$ & & $64.09^{\circ} \mathrm{N}-21.56^{\circ} \mathrm{W}$ \\
\hline Sea water & SWFAR01 & $\begin{array}{l}\text { Torshavn, Utfyri } \\
\text { skipasmiduna }\end{array}$ & $531 \mathrm{~g}$ & 21.08.2003 & & $62.00^{\circ} \mathrm{N}-06.46^{\circ} \mathrm{W}$ \\
\hline Sea water & SWFAR02 & $\begin{array}{l}\text { Torshavn, Utfyri } \\
\text { skipasmiduna }\end{array}$ & $362 \mathrm{~g}$ & 21.08.2003 & & $62.00^{\circ} \mathrm{N}-06.46^{\circ} \mathrm{W}$ \\
\hline Sea water & SWFAR03 & $\begin{array}{l}\text { Torshavn, Utfyri } \\
\text { skipasmiduna }\end{array}$ & $520 \mathrm{~g}$ & 21.08.2003 & & $62.00^{\circ} \mathrm{N}-06.46^{\circ} \mathrm{W}$ \\
\hline Sewage effluent & SEFAR04 & Yviri vid Strond & $512 g$ & 15.10.2003, 11.00h & & $62.00^{\circ} \mathrm{N}-06.46^{\circ} \mathrm{W}$ \\
\hline Sediment & SDFAR05 & $\begin{array}{l}\text { Landingarplassi i } \\
\text { Vagsbotni }\end{array}$ & $5.0 \mathrm{~g}$ & 21.08.2003 & & $62.00^{\circ} \mathrm{N}-06.46^{\circ} \mathrm{W}$ \\
\hline Sediment & SDFAR06 & $\begin{array}{l}\text { Torshavn, Utfyri } \\
\text { skipasmiduna }\end{array}$ & $5.2 \mathrm{~g}$ & 21.08 .2003 & & $62.00^{\circ} \mathrm{N}-06.46^{\circ} \mathrm{W}$ \\
\hline & & & & & & \\
\hline
\end{tabular}




\begin{tabular}{|c|c|c|c|c|c|c|}
\hline Sample type & Sample ID & $\begin{array}{l}\text { Sampling } \\
\text { location }\end{array}$ & Sample amount analysed & Sampling date/ time & Additional information & $\begin{array}{l}\text { Position: Lat. - } \\
\text { Long. }\end{array}$ \\
\hline Sediment & SDFAR07 & Fjardakanningar & $4.8 \mathrm{~g}$ & 02.09 .2003 & & $62.00^{\circ} \mathrm{N}-06.46^{\circ} \mathrm{W}$ \\
\hline Sewage & SSFAR08 & $\begin{array}{l}\text { Torshavn, } \\
\text { Sersjandvikin }\end{array}$ & $5.1 \mathrm{~g}$ & 19.08 .2003 & & $62.00^{\circ} \mathrm{N}-06.46^{\circ} \mathrm{W}$ \\
\hline
\end{tabular}




\section{Appendix 2: Sampling manual}

Nordic cooperation on screening of perfluorinated substances

\section{Sampling and sample handling manual}

Prepared by

Urs Berger, Norwegian Institute for Air Research (NILU)

The Polar Environmental Centre, Hjalmar Johansens gt. 14

NO-9296 Tromsø, Norway

e-mail: urs.berger@nilu.no

in cooperation with

Ulf Järnberg, Institute of Applied Environmental Research (ITM)

Stockholm University, SE-106 91 Stockholm , Sweden 


\section{Introduction and objectives of the study}

These guidelines concern the sampling, sample handling and shipping of water, sediment, sludge, fish liver and seal liver for trace analysis of organic contaminants. They are suitable for perfluoroalkylated substances (PFAS) such as perfluoroalkylated acids, perfluoroalkylated sulfonates and their derivatives. The institutes performing the chemical trace analysis do not take any responsibility for representativeness of samples or contamination problems during sampling, sample storage and shipping to the respective laboratories. These guidelines should be followed as precisely as possible and any deviations from the guidelines must be reported in the sampling protocols.

The purpose of this study is a first quantitative screening of perfluorooctyl sulfonate (PFOS), perfluorohexyl sulfonate (PFHS), perfluorooctanoic acid (PFOA), perfluorononanoic acid (PFNA) and perfluorooctyl sulfonamide (PFOSA) (Figure 1) contaminants in water (freshwater, seawater, effluents and rainwater), sediment, sludge, fish liver and seal liver from the Nordic countries (i.e. Denmark, Sweden, Finland, Norway, Iceland and Faeroe Islands). This will allow to assess the existing level of contamination (spatial distribution monitoring) possibly indicating regional differences. The spatial distribution monitoring programme will enable to determine the representativeness of the monitoring sites with regard to spatial variability in contaminant concentrations and will give information about the ubiquity of PFAS distribution in the Nordic countries.

\section{Perfluoroalkylated substances (PFAS)}

Perfluoroalkylated substances (PFAS) have been manufactured for more than 50 years. They are used for a large number of industrial applications such as protection of carpets, textiles, leather products as well as in the production of fire-fighting foams, herbicides and insecticides, lubricants, paints, adhesives and acid etching solutions (Kannan et al., 2001; Laikhtman and Rohrer, 1998; RIKZ 2002). About 3250 tons of PFOS-based chemicals were produced by the $3 \mathrm{M}$ company (USA) in 2000 . Though the manufacturer voluntarily has phased out most of this production volume, similar compounds with long perfluorinated chains, continue to be produced for comparable applications. Compared to hydrocarbons, perfluorinated compounds display exceptional physical properties:

I) They are immiscible with most other liquids.

II) Fluoro-organics are non-flammable and non-corrosive.

III) Perfluorinated compounds have a very high insulation resistance.

The exceptional properties making man-made PFAS so attractive for industrial applications also impose a risk for the environment and ecological systems. The strength of the carbon-fluorine bond makes these compounds very persistent towards degradation. Recent publications indicated that PFAS and especially PFOS are widely distributed over the northern hemisphere, including remote areas such as the Arctic (Giesy and Kannan, 2001; Hansen et al., 2002; Kannan et al., 2001).

\section{General sampling strategy}

Sampling should be performed in accordance with general sampling strategies for chemical trace analysis. In case of questions about the practicability of procedures or 
usability of special material and equipment NILU must be contacted (Roland Kallenborn, phone: +47 777503 86, e-mail: roland.kallenborn@,nilu.no; Urs Berger, phone: +47 777503 85, e-mail: urs.berger@nilu.no). The sampling strategy should take into account the specific objectives of the monitoring programme, including the quantitative objectives. Natural variability within the samples should be reduced by an appropriate sampling design. The sampling strategy is an intrinsic component of the data, and may limit their use and interpretation.

\subsection{Sampling site selection / representative sampling}

Nothing is known about the homogeneity of the distribution of PFAS in the Nordic environment, since no comprehensive screening has been performed in these countries yet. Therefore, it is difficult to give recommendations about the choice of representative sampling sites. Only a relatively high number of samples taken from as many different places as possible can overcome this challenge and will add to our knowledge about distribution patterns of PFAS in the environment. The detailed sampling site selection lies within the responsibility of the sampling institutes. Sampling sites must be indicated on the sampling protocols as accurate as possible (preferably with latitude/longitude data).

\subsection{Homogeneity of samples}

Primary sample amounts should be as large as feasible and homogenised on site to yield sub-samples of at least the required volume for analysis (see Chapter 5). Larger sample amounts are preferred (and mandatory for some samples of each matrix) to perform laboratory replicate studies. These as well as field replicate studies (see Chapter 7.2) are an integrated part of the quality assurance programme of the planned study.

\section{Sampling equipment / risk of contamination}

All equipment, materials and containers that come in contact with the samples must be rinsed with high-purity water and methanol before use. Fluoropolymeric materials pose a significant risk of contamination with PFAS, especially for PFOA. Equipment made of or containing fluoropolymers such as PTFE ('Teflon') or Viton rubber (sealing rings etc.) must not be in direct contact with the samples and should completely be avoided when handling, storing or shipping samples. The target analytes are surface-active compounds. Furthermore, they display very poor solubility both in water and organic solvents. Currently there is no consensus among experts as to whether PFAS adsorb irreversibly to glass surfaces or not. Glass containers should therefore be avoided and replaced by polyethylene (not PTFE!). NILU must be contacted in case of questions about the usability of certain materials in contact with samples (Roland Kallenborn, phone: +4777750386, e-mail: roland.kallenborn@,nilu.no; Urs Berger, phone: +4 77750385, e-mail: urs.berger@nilu.no). Samples should be collected in the same containers in which they are cooled/frozen, stored and shipped to the analysing laboratories to avoid losses due to adsorption and change of vessels.

\section{Field sampling / required sample amounts}

\subsection{Water}

General water sampling strategies for chemical trace analysis should be followed. Sample amounts of $500-1000 \mathrm{ml}$ are required to guarantee good detection limits. The sampling depth in lakes and the sea is crucial. Due to their surface-active properties, PFAS might form a layer on water surfaces or preferably bind to particles. Therefore, it 
is important to state if samples were collected on the water surface, several meters from surface and bottom or close to the bottom. Water samples should be kept cool (but not frozen) and in darkness in order to avoid degradation of analytes.

\subsection{Sediment}

General sediment sampling strategies for chemical trace analysis should be followed. PFAS are expected to be distributed unevenly in sediments. Therefore, as much sediment as feasible should be collected over a large area and thoroughly blended before an aliquot is taken. A homogenous aliquot of approx. $100 \mathrm{~g}$ should be sent cooled to the analysing laboratory.

\subsection{Sludge}

PFAS are expected to be distributed unevenly in sludge. Therefore, as much sludge as feasible should be collected and thoroughly mixed before an aliquot is taken. A homogenous aliquot of approx. $100 \mathrm{~g}$ should be sent cooled to the analysing laboratory.

\subsection{Fish and seal liver}

Fish and seals should be dissected immediately after collection and liver samples should be removed and frozen. The fish liver samples should be pooled samples prepared from at least 10 individuals of similar size (weight and length). The weight of the total pooled sample should in any case exceed $5 \mathrm{~g}$. Fish caught during the non-breeding season is preferred over fish from the breeding period. The seal liver samples should preferably be prepared as pooled samples from several individuals if this is feasible, since seals have shown a large variability in PFAS concentrations. A minimum of $5 \mathrm{~g}$ seal liver sample is requested for analysis. All biological samples must be frozen immediately after catch and preparation.

\section{Storage and shipping of samples}

The target analytes are generally very stable towards degradation. Therefore, the time between sampling and analysis is not expected to be crucial in this study. However, little is known about enzymatic degradation, therefore all samples should be kept cold and especially biological samples should be frozen $\left(-18{ }^{\circ} \mathrm{C}\right)$ immediately after

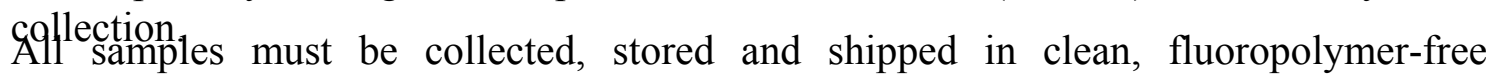
containers, preferably polyethylene vessels should be used (see Chapter 4). Containers should not be changed from the moment of sampling or preparation to the arrival at the analytical laboratories.

\subsection{Water, sediment and sludge samples}

Water, sediment and sludge samples must be cooled $\left(<4{ }^{\circ} \mathrm{C}\right)$ after collection. Water samples should not be frozen. All samples should be stored and shipped at low temperatures and in darkness. They must be clearly and unmistakably marked with a sample name and sent together with their sampling protocols by an express delivery service (TNT, DHL, EMS or similar) to the following address:

Norwegian Institute for Air Research (NILU) , Instituttveien 18 ,NO-2027 Kjeller Norway

To assure that samples reach the destination within short time (usually within the same day), they should be sent early in the morning and not on a Friday (preferably Monday to Wednesday). When sending the samples a notice including the airway bill number 
(AWB) of the package must be sent to NILU to the following fax number: ++476389 8050 addressed to Arve Bjerke and Ellen Katrin Enge. The delivery should be marked with "samples NMR-PFAS study" to avoid unnecessary delay during the registration procedure at the analysing institute.

\subsection{Fish and seal liver samples}

Biological samples (fish and seal liver) must be kept frozen during storage $\left(<-18^{\circ} \mathrm{C}\right)$. During transportation, an insulated box should be used to ensure that the temperature does not exceed thawing temperature $\left(<0{ }^{\circ} \mathrm{C}\right)$. All samples must be clearly and unmistakably marked with a sample name and sent together with their sampling protocols by an express delivery service (TNT, DHL, EMS or similar) to the following address:

Ulf Järnberg : Institute of Applied Environmental Research (ITM) , Stockholm University SE-106 91 Stockholm, Sweden

To assure that samples reach the destination within short time (usually within the same day), they should be sent early in the morning and not on a Friday (preferably Monday to Wednesday). When sending the samples a notice including the airway bill number (AWB) of the package must be sent to ITM to the following fax number: ++468674 7637 addressed to Ulf Järnberg. The delivery should be marked with "samples NMRPFAS study" to avoid unnecessary delay during the registration procedure at the analysing institute.

\section{Sampling quality assurance}

Quality assurance is a management scheme required to ensure the consistent delivery of quality controlled data. To minimise the risk of contamination or the loss of analytes (and so to avoid the generation of false data) all procedures including sampling, storage and shipping must be evaluated and controlled. This is partly done by analysing field blanks and replicates. Furthermore, sample replicates allow to assess the precision of the complete analytical method. Field blank and replicate samples will be analysed and reported in addition to the 100 samples without additional costs. The steering group of the Nordic Chemicals Group decides where blank and duplicate samples will be taken and is responsible for the distribution of these tasks (see also 7.1 and 7.2).

\subsection{Field blanks}

Field blanks must be taken parallel to the samples for all matrices at five different sampling sites. For water, sediment and sludge the blank surrogate matrix must be treated in exactly the same way as the real samples from the moment of sampling in the field. As surrogate matrix for water analysis high-purity water should be used, for sediment analysis high-purity silica should be employed. A slurry mixture of highpurity water and silica with similar water content as the sludge samples (i.e. only silica if desiccated sludge is sampled) should be used as blank surrogate matrix for sludge analysis. For fish and seal liver the blank surrogate matrix must be treated in exactly the same way as the real samples from the moment of dissection of the animal and isolation of the liver. Triolin (= 1,2,3-tri-(cis-9-octadecenoyl) glycerol) should be used as liver surrogate matrix for field blank experiments. 


\subsection{Field replicates}

Additionally to the blank and real samples, duplicate samples must be taken for all matrices at a minimum of three different sampling sites (preferably three different countries). These samples will be used to assess the repeatability and representativeness of the sampling procedures. The duplicates must in each case be two independent samples simultaneously taken from the same site and not two aliquots from the same primary sample homogenate. It has to be indicated on the sampling protocols which samples belong together as field duplicates.

\section{References}

- Giesy J.P., Kannan K. (2001) Environ. Sci. Technol. 35, 1339-1342

- Hansen K.J., Johnson H.O., Eldridge J.S., Butenhoff J.L., Dick L.A. (2002) Environ. Sci. Technol. 36, 1681-1685

- Kannan K., Koistinen J., Beckmen K., Evans T., Gorzelany J.F., Hansen K.J., Jones P.D., Helle E., Nyman M., Giesy J.P. (2001) Environ. Sci. Technol. 35, 15931598

- Laikhtman M., Rohrer J.S. (1998) J. Chrom. A 822, 321-325

- RIKZ (2002) Perfluoroalkylated substances, aquatic environmental assessment; report RIKZ/2002.043, Hekster F.M., de Voogt P., Pijnenburg A.M.C.M., Laane R.W.P.M. (authors), Directoraat-Generaal Rijkswaterstaat, Rijksinstituut voor Kust en Zee, Den Haag, The Netherlands 
Annex 1: Sampling protocol for sea-/river-/lake-water samples

\begin{tabular}{|l|l}
\hline Sample name: & Sample material:
\end{tabular}

\begin{tabular}{|l|l|l|}
\hline \multicolumn{2}{|l|}{ Sampling } & Comments \\
\hline Date and time: & & \\
\hline $\begin{array}{l}\text { Site (description, preferably } \\
\text { with latitude/longitude data): }\end{array}$ & & \\
\hline $\begin{array}{l}\text { Approx. sampling depth } \\
\text { (distance from surface): }\end{array}$ & & \\
\hline $\begin{array}{l}\text { Approx. distance from } \\
\text { bottom/shore: }\end{array}$ & & \\
\hline Sample volume: & & \\
\hline Water temperature: & $\begin{array}{l}\text { Transport temperature after } \\
\text { sampling: }\end{array}$ & \\
\hline $\begin{array}{l}\text { Special observations / } \\
\text { deviations from sampling } \\
\text { procedure: }\end{array}$ & & \\
\hline
\end{tabular}

\begin{tabular}{|l|l|l|}
\hline Storage & & Comments \\
\hline Storage time: & & \\
\hline Storage temperature: & & \\
\hline Special observations: & & \\
\hline
\end{tabular}

\begin{tabular}{|l|l|l|}
\hline Shipping & & Comments \\
\hline Date sample sent: & & \\
\hline Shipping temperature: & & \\
\hline Date sample received*: & & \\
\hline Condition upon receipt*: & & \\
\hline Special observations*: & & \\
\hline$*$ To be filled in by NILU &
\end{tabular}


Annex 2: Sampling protocol for effluent water samples

\begin{tabular}{|l|l|}
\hline Sample name: & Sample material: \\
\hline
\end{tabular}

\begin{tabular}{|c|c|}
\hline Sampling & \multirow[t]{2}{*}{ Comments } \\
\hline Date and time: & \\
\hline $\begin{array}{l}\text { Site (description, preferably } \\
\text { with latitude/longitude data): }\end{array}$ & \\
\hline $\begin{array}{l}\text { Origin of effluent water } \\
\text { (industry, households, } \\
\text { hospital etc.): }\end{array}$ & \\
\hline $\begin{array}{l}\text { Effluent treatment before } \\
\text { sampling (biological, } \\
\text { filtration etc.):: }\end{array}$ & \\
\hline Sample volume: & \\
\hline Water temperature: & \\
\hline $\begin{array}{l}\text { Transport temperature after } \\
\text { sampling: }\end{array}$ & \\
\hline $\begin{array}{l}\text { Special observations / } \\
\text { deviations from sampling } \\
\text { procedure: }\end{array}$ & \\
\hline
\end{tabular}

\begin{tabular}{|l|l|l|}
\hline Storage & & Comments \\
\hline Storage time: & & \\
\hline Storage temperature: & & \\
\hline Special observations: & & \\
\hline
\end{tabular}

\begin{tabular}{|l|l|l|}
\hline Shipping & & Comments \\
\hline Date sample sent: & & \\
\hline Shipping temperature: & & \\
\hline Date sample received*: & & \\
\hline Condition upon receipt*: & & \\
\hline Special observations": & & \\
\hline
\end{tabular}

* To be filled in by NILU 
Annex 3: Sampling protocol for rainwater samples

\begin{tabular}{|l|l}
\hline Sample name: & Sample material: \\
\hline
\end{tabular}

\begin{tabular}{|l|l|l|}
\hline \multicolumn{2}{|l|}{ Sampling } & Comments \\
\hline $\begin{array}{l}\text { Date (period of rainwater } \\
\text { collection): }\end{array}$ & \\
\hline $\begin{array}{l}\text { Site (description, preferably } \\
\text { with latitude/longitude data): }\end{array}$ & & \\
\hline Rainwater collection device: & & \\
\hline Sample volume: & & \\
\hline $\begin{array}{l}\text { Transport temperature after } \\
\text { sampling: }\end{array}$ & & \\
\hline $\begin{array}{l}\text { Special observations / } \\
\text { deviations from sampling } \\
\text { procedure: }\end{array}$ & & \\
\hline
\end{tabular}

\begin{tabular}{|l|l|l|}
\hline Storage & & Comments \\
\hline Storage time: & & \\
\hline Storage temperature: & & \\
\hline Special observations: & \multicolumn{2}{|l|}{} \\
\hline
\end{tabular}

\begin{tabular}{|l|l|l|}
\hline Shipping & & Comments \\
\hline Date sample sent: & & \\
\hline Shipping temperature: & & \\
\hline Date sample received*: & & \\
\hline Condition upon receipt*: & & \\
\hline Special observations*: & \multicolumn{2}{|l|}{} \\
\hline
\end{tabular}

* To be filled in by NILU 
Annex 4: Sampling protocol for sediment samples

Sample name:

Sample material:

\begin{tabular}{|l|l|l|}
\hline \multicolumn{2}{|l|}{ Sampling } & Comments \\
\hline Date and time: & & \\
\hline $\begin{array}{l}\text { Site (description, water } \\
\text { depth, latitude/longitude) }\end{array}$ & \\
\hline $\begin{array}{l}\text { Water current conditions at } \\
\text { sampling site: }\end{array}$ & & \\
\hline $\begin{array}{l}\text { Sample layer depth (digging } \\
\text { depth): }\end{array}$ & & \\
\hline $\begin{array}{l}\text { Total primary sample } \\
\text { amount: }\end{array}$ & & \\
\hline Homogenous aliquot amount: & & \\
\hline $\begin{array}{l}\text { Transport temperature after } \\
\text { sampling: }\end{array}$ & & \\
\hline $\begin{array}{l}\text { Special observations / } \\
\text { deviations from sampling } \\
\text { procedure: }\end{array}$ & & \\
\hline
\end{tabular}

\begin{tabular}{|l|l|l|}
\hline Storage & & Comments \\
\hline Storage time: & & \\
\hline Storage temperature: & & \\
\hline Special observations: & \multicolumn{2}{|l}{} \\
\hline
\end{tabular}

\begin{tabular}{|l|l|l|}
\hline Shipping & & Comments \\
\hline Date sample sent: & & \\
\hline Shipping temperature: & & \\
\hline Date sample received*: & & \\
\hline Condition upon receipt*: & & \\
\hline Special observations*: & & \\
\hline
\end{tabular}

* To be filled in by NILU 
Annex 5: Sampling protocol for sludge samples

\begin{tabular}{|l|l}
\hline Sample name: & Sample material:
\end{tabular}

\begin{tabular}{|l|l|l|}
\hline \multicolumn{2}{|l|}{ Sampling } & Comments \\
\hline Date and time: & & \\
\hline $\begin{array}{l}\text { Site (description, preferably } \\
\text { with latitude/longitude data): }\end{array}$ & & \\
\hline $\begin{array}{l}\text { Total primary sample } \\
\text { amount: }\end{array}$ & & \\
\hline Homogenous aliquot amount: & & \\
\hline $\begin{array}{l}\text { Transport temperature after } \\
\text { sampling: }\end{array}$ & & \\
\hline $\begin{array}{l}\text { Special observations/ } \\
\text { deviations from sampling } \\
\text { procedure: }\end{array}$ & & \\
\hline
\end{tabular}

\begin{tabular}{|l|l|l|}
\hline Storage & & Comments \\
\hline Storage time: & & \\
\hline Storage temperature: & & \\
\hline Special observations: & \multicolumn{2}{|l}{} \\
\hline
\end{tabular}

\begin{tabular}{|l|l|l|}
\hline Shipping & & Comments \\
\hline Date sample sent: & & \\
\hline Shipping temperature: & & \\
\hline Date sample received*: & & \\
\hline Condition upon receipt*: & & \\
\hline Special observations*: & \multicolumn{2}{|l}{} \\
\hline
\end{tabular}

* To be filled in by NILU 
Annex 6: Sampling protocol for fish liver samples

\begin{tabular}{|l|l|}
\hline Sample name: & Sample material: \\
\hline
\end{tabular}

\begin{tabular}{|l|l|l|}
\hline \multicolumn{2}{|l|}{ Sampling } & Comments \\
\hline Date: & & \\
\hline $\begin{array}{l}\text { Site (description, preferably } \\
\text { with latitude/longitude data): }\end{array}$ & & \\
\hline $\begin{array}{l}\text { Number and size of } \\
\text { individuals used for the } \\
\text { pooled fish liver sample: }\end{array}$ & $\begin{array}{l}\text { Age and sex of the } \\
\text { individuals (if possible): }\end{array}$ & \\
\hline $\begin{array}{l}\text { Physiological condition of } \\
\text { individuals when caught: }\end{array}$ & & \\
\hline $\begin{array}{l}\text { Storage temp. after sampling: } \\
\text { Date and site of dissection: }\end{array}$ & & \\
\hline $\begin{array}{l}\text { Total liver sample amount: } \\
\text { dissection): }\end{array}$ & & \\
\hline $\begin{array}{l}\text { Special observations (e.g. } \\
\text { ding and re-freezing for }\end{array}$ & & \\
\hline
\end{tabular}

\begin{tabular}{|l|l|l|}
\hline Storage & & Comments \\
\hline Storage time: & & \\
\hline Storage temperature: & & \\
\hline Special observations: & & \\
\hline
\end{tabular}

\begin{tabular}{|l|l|l|}
\hline Shipping & & Comments \\
\hline Date sample sent: & & \\
\hline Shipping temperature: & & \\
\hline Date sample received*: & & \\
\hline Condition upon receipt*: & & \\
\hline Special observations*: & & \\
\hline
\end{tabular}

* To be filled in by ITM 
Annex 7: Sampling protocol for seal liver samples

\begin{tabular}{|l|l|}
\hline Sample name: & Sample material: \\
\hline
\end{tabular}

\begin{tabular}{|l|l|l|}
\hline \multicolumn{2}{|l|}{ Sampling } & Comments \\
\hline Date: & & \\
\hline $\begin{array}{l}\text { Site (description, preferably } \\
\text { with latitude/longitude data): }\end{array}$ & & \\
\hline $\begin{array}{l}\text { Number of individuals used } \\
\text { for the pooled liver sample: }\end{array}$ & & \\
\hline $\begin{array}{l}\text { Age and sex of the } \\
\text { individuals (if possible): }\end{array}$ & & \\
\hline Cause of death: & & \\
\hline Storage temp. after sampling: & & \\
\hline Date and site of dissection: & & \\
\hline $\begin{array}{l}\text { Exact tissue location of } \\
\text { prepared sample, in case only } \\
\text { a part of tissue was prepared: }\end{array}$ & & \\
\hline Total liver sample amount: & & \\
\hline $\begin{array}{l}\text { Special observations / } \\
\text { deviations from sampling } \\
\text { procedure: }\end{array}$ & & \\
\hline
\end{tabular}

\begin{tabular}{|l|l|l|}
\hline Storage & & Comments \\
\hline Storage time: & & \\
\hline Storage temperature: & & \\
\hline Special observations: & & \\
\hline
\end{tabular}

\begin{tabular}{|l|l|l|}
\hline Shipping & & Comments \\
\hline Date sample sent: & & \\
\hline Shipping temperature: & & \\
\hline Date sample received*: & & \\
\hline Condition upon receipt*: & & \\
\hline Special observations*: & \multicolumn{2}{|l}{} \\
\hline
\end{tabular}

* To be filled in by ITM 


\section{Nordic cooperation on screening of perfluorinated substances}

Supplementary information:

Sampling and sample handling manual from 04.07.2003

\section{Sludge samples:}

Recent literature suggested that PFOS and PFOA could be anaerobically biodegraded in activated sludge (Schröder, 2003). This problem might occur in wet sludge samples kept at ambient or higher temperatures. To avoid the possibility of degradation of analytes the following recommendations should be followed when sampling, storing and shipping sludge samples: - Drained sludge samples (dry samples) are preferred over wet samples. Analysing only dry sludge would also guarantee the comparability between sludge samples from different countries. - Samples should be frozen immediately after sampling and kept frozen during storage and shipping. - If dry or drained sludge is not available, wet sludge samples with high water content can be deactivated by adding $0.5 \%$ (weight) of formic acid ( $\mathrm{HCOOH})$. This treatment must be clearly indicated on the sampling protocol. These samples should be cooled but not frozen (compare also water samples).

Reference: Schröder H.F. (2003) J. Chrom. A (2003), 1020: 131-151 


\section{Appendix 3: Concentration list}

\begin{tabular}{|c|c|c|c|c|c|c|c|c|}
\hline \multirow[b]{2}{*}{ Sample no } & \multirow[b]{2}{*}{ Type } & \multicolumn{3}{|c|}{ Sediment-sludge } & \multicolumn{2}{|c|}{$[p g / g ~ w w]$} & \multirow[b]{2}{*}{ PFNA } & \multirow[b]{2}{*}{ SUM } \\
\hline & & PFOSA & PFHxS & PFOS & PFHxA & PFOA & & \\
\hline SDFIN10a & Sediment (sub-samples) & $<L O Q$ & 45 & 892 & 138 & $<L O Q$ & 72 & 1147 \\
\hline SDFIN10b & Sediment (sub-samples) & $<L O Q$ & 47 & 861 & 159 & $<L O Q$ & 64 & 1131 \\
\hline SDFIN10c & Sediment (sub-samples) & $<L O Q$ & 44 & 1014 & 135 & $<L O Q$ & 46 & 1238 \\
\hline SDFIN11 & Sediment & $<L O Q$ & 26 & 222 & $<L O Q$ & $<L O Q$ & $<L O Q$ & 247 \\
\hline SDFIN12 & Sediment & $<L O Q$ & 41 & 290 & 46 & $<L O Q$ & $<L O Q$ & 377 \\
\hline SSFIN13 & Sewage sludge & $<L O Q$ & 91 & 158 & 1152 & 754 & 171 & 2326 \\
\hline SSFIN14a & Sewage sludge (sub-samples) & $<L O Q$ & 46 & 846 & 792 & 546 & $<L O Q$ & 2230 \\
\hline SSFIN14b & Sewage sludge (sub-samples) & $<L O Q$ & 38 & 663 & 932 & 580 & $<L O Q$ & 2213 \\
\hline SSFIN14C & Sewage sludge (sub-samples) & $<L O Q$ & 51 & 925 & 838 & 707 & $<L O Q$ & 2521 \\
\hline SSFIN15 & Sewage sludge & $<L O Q$ & $<L O Q$ & 327 & $<L O Q$ & 602 & 119 & 1048 \\
\hline SSFIN16 & Sewage sludge & $<L O Q$ & $<L O Q$ & 55 & $<$ LOD & $<L O Q$ & 95 & 150 \\
\hline SSSWE07 & Sewage sludge & $<L O Q$ & 17 & 167 & $<L O Q$ & $<L O Q$ & $<L O Q$ & 184 \\
\hline SSSWE08 & Sewage sludge & $<L O Q$ & $<L O Q$ & 274 & $<L O Q$ & 250 & $<L O Q$ & 524 \\
\hline SSSWE09 & Sewage sludge & 94 & 46 & 2644 & $<L O Q$ & 779 & 229 & 3793 \\
\hline SDSWE04 & Sediment & $<L O Q$ & $<L O Q$ & 69 & $<L O Q$ & $<L O Q$ & $<\mathrm{LOQ}$ & 69 \\
\hline SDSWE05 & Sediment & $<L O Q$ & $<L O Q$ & $<L O Q$ & $<L O Q$ & $<L O Q$ & $<L O Q$ & $<L O Q$ \\
\hline SDSWE06 & Sediment & $<L O Q$ & $<L O Q$ & $<L O Q$ & $<L O Q$ & $<L O Q$ & $<L O Q$ & $<L O Q$ \\
\hline
\end{tabular}




\begin{tabular}{|c|c|c|c|c|c|c|c|c|}
\hline Sample no. & Type & PFOSA & PFHxS & PFOS & PFHXA & PFOA & PFNA & SUM \\
\hline SDNOR12 & Sediment & $<L O Q$ & & & 143 & & 32 & 175 \\
\hline SDNOR13 & Sediment & $<\mathrm{LOQ}$ & 8 & 394 & 80 & 278 & 88 & 848 \\
\hline SDNOR14 & Sediment & $<L O Q$ & 30 & 217 & 102 & 312 & $<L O Q$ & 661 \\
\hline SSNOR15 & Sewage sludge & $<L O Q$ & 25 & 1023 & 126 & 377 & 103 & 1654 \\
\hline SSNOR16 & Sewage sludge & $<L O Q$ & 18 & 449 & $<L O Q$ & 391 & 190 & 1048 \\
\hline SSDAN04 & Sewage & $<L O Q$ & 14 & 1041 & $<L O Q$ & 392 & 87 & 1533 \\
\hline SSDAN05 & Sewage & 20 & 13 & 316 & $<L O Q$ & 306 & $<L O Q$ & 655 \\
\hline SSDAN06 & Sewage & $<L O Q$ & 9 & 416 & $<L O Q$ & 675 & 232 & 1333 \\
\hline SSICE02a & Sediment (sub-sample) & $<L O Q$ & $<L O Q$ & $<L O Q$ & $<L O Q$ & $<L O Q$ & $<\mathrm{LOQ}$ & $<\mathrm{LOQ}$ \\
\hline SSICE02b & Sediment (sub-sample) & $<L O Q$ & $<L O Q$ & $<L O Q$ & $<L O Q$ & $<L O Q$ & $<L O Q$ & $<L O Q$ \\
\hline SSICE02C & Sediment (sub-sample) & $<L O Q$ & $<L O Q$ & $<L O Q$ & $<L O Q$ & $<L O Q$ & $<L O Q$ & $<L O Q$ \\
\hline SSICE02d & Sediment (sub-sample) & $<L O Q$ & $<L O Q$ & $<L O Q$ & $<L O Q$ & $<L O Q$ & $<L O Q$ & $<L O Q$ \\
\hline SSICE03a & Sewage (sub-samples) & $<L O Q$ & 19 & 160 & $<L O Q$ & $<L O Q$ & $<L O Q$ & 179 \\
\hline SSICE03b & Sewage (sub-samples) & $<L O Q$ & 15 & 220 & $<L O Q$ & $<L O Q$ & $<L O Q$ & 234 \\
\hline SSICE04a & Sewage (sub-samples) & $<L O Q$ & 15 & 69 & $<\mathrm{LOQ}$ & 298 & $<L O Q$ & 381 \\
\hline SSICE04b & Sewage (sub-samples) & $<L O Q$ & 12 & 79 & $<\mathrm{LOQ}$ & 251 & $<L O Q$ & 342 \\
\hline SDFAR05 & Sediment & $<L O Q$ & $<L O Q$ & 111 & $<L O Q$ & $<L O Q$ & $<L O Q$ & 111 \\
\hline SDFAR06 & Sediment & $<L O Q$ & $<L O Q$ & $<L O Q$ & $<L O Q$ & $<L O Q$ & $<L O Q$ & $<L O Q$ \\
\hline SDFAR07 & Sediment & $<L O Q$ & $<L O Q$ & 54 & 93 & $<L O Q$ & 31 & 178 \\
\hline SSFAR08 & Sewage & $<L O Q$ & 15 & 241 & 346 & 1075 & $<L O Q$ & 1677 \\
\hline
\end{tabular}


Aqueous samples

[ng/L]

\begin{tabular}{|c|c|c|c|c|c|c|c|c|c|}
\hline Sample no. & Type & PFOSA & PFBS & PFHxS & PFOS & PFHxA & PFOA & PFNA & SUM \\
\hline SWFIN01 & Sea water & $<L O Q$ & 0.93 & 4.39 & 21.7 & 4.35 & 5.19 & 0.84 & 37 \\
\hline SWFIN02 & Sea water & $<L O Q$ & 0.12 & 0.24 & 0.86 & 0.77 & 3.97 & 0.18 & 6 \\
\hline SWFIN04 & Sea water & 0.07 & $<\mathrm{LOQ}$ & 0.25 & 1.11 & 0.94 & 5.60 & 0.24 & 8 \\
\hline RWFIN05 & Rain water & 0.07 & $<L O Q$ & $<L O Q$ & 0.32 & 1.90 & 13.1 & 0.74 & 16 \\
\hline LFFIN07a & $\begin{array}{l}\text { Landfill effluent water } \\
\text { (sub-samples) }\end{array}$ & 0.71 & $<\mathrm{LOQ}$ & 158 & 33.5 & 139 & 399 & 55.0 & 785 \\
\hline LFFIN07b & $\begin{array}{l}\text { Landfill effluent water } \\
\text { (sub-samples) }\end{array}$ & 0.64 & 68.0 & 112 & 30.2 & 165 & 300 & 61.3 & 737 \\
\hline LFFIN07c & $\begin{array}{l}\text { Landfill effluent water } \\
\text { (sub-samples) }\end{array}$ & 0.51 & 61.3 & 159 & 34.7 & 152 & 306 & 51.3 & 764 \\
\hline SEFIN08 & Sewage effluent water & $<L O Q$ & 3.01 & 3.71 & 62.6 & 8.08 & 20.9 & 7.09 & 105 \\
\hline SEFIN09a & $\begin{array}{l}\text { Sewage effluent water } \\
\text { (sub-samples) }\end{array}$ & 0.48 & 2.61 & 3.40 & 8.83 & 10.4 & 19.9 & 2.42 & 48 \\
\hline SEFIN09b & $\begin{array}{l}\text { Sewage effluent water } \\
\text { (sub-samples) }\end{array}$ & 0.46 & 3.09 & 4.66 & 10.0 & 13.5 & 22.8 & 2.51 & 57 \\
\hline RWSWE01a & Rainwater (sub-samples) & $<L O Q$ & $<L O Q$ & 0.39 & 2.54 & 1.10 & 15.3 & 1.34 & 21 \\
\hline RWSWE01b & Rainwater (sub-samples) & $<L O Q$ & $<\mathrm{LOQ}$ & 0.36 & 2.39 & 1.18 & 16.8 & 1.26 & 22 \\
\hline RWSWE02 & Rainwater & 0.07 & $<\mathrm{LOQ}$ & 0.15 & 0.83 & 0.81 & 10.7 & 0.63 & 13 \\
\hline RWSWE03 & Rainwater & 0.14 & $<L O Q$ & 0.59 & 2.97 & 1.14 & 15.1 & 1.41 & 21 \\
\hline
\end{tabular}




\begin{tabular}{|c|c|c|c|c|c|c|c|c|c|}
\hline Sample no. & Type & PFOSA & PFBS & PFHxS & PFOS & PFHxA & PFOA & PFNA & SUM \\
\hline LWNOR01 & Lake water & $<\mathrm{LOQ}$ & $<\mathrm{LOQ}$ & $<\mathrm{LOQ}$ & $<\mathrm{LOQ}$ & 1.47 & 7.77 & 0.24 & 9 \\
\hline LWNOR02 & Lake water & $<\mathrm{LOQ}$ & $<\mathrm{LOQ}$ & $<\mathrm{LOQ}$ & $<\mathrm{LOQ}$ & 1.68 & 8.23 & 0.23 & 10 \\
\hline LWNOR03 & Lake water & $<L O Q$ & $<\mathrm{LOQ}$ & 0.10 & 0.43 & 1.27 & 8.21 & 0.12 & 10 \\
\hline LWNOR04a & Lake water & $<L O Q$ & $<L O Q$ & 0.11 & 0.48 & 0.76 & 4.82 & 0.30 & 6 \\
\hline LWNOR04b & Lake water & $<L O Q$ & $<\mathrm{LOQ}$ & 0.08 & 0.40 & 0.91 & 5.01 & 0.30 & 7 \\
\hline LFNOR05a & Landfill effluent & 0.06 & 12.7 & 11.6 & 33.0 & 47.9 & 91.3 & 4.16 & 201 \\
\hline LFNOR05b & Landfill effluent & 0.09 & 12.2 & 13.1 & 33.0 & 43.7 & 93.5 & 3.50 & 199 \\
\hline LFNOR06 & Landfill effluent & 3.28 & 112 & 70.9 & 108 & 697 & 516 & 30.9 & 1537 \\
\hline LFNOR07 & Landfill effluent & $<L O Q$ & 5.64 & 62.6 & 56.4 & 26.4 & 293 & 61.5 & 505 \\
\hline LFNOR08 & Landfill effluent & 3.04 & 98.9 & 143 & 187 & 311 & 367 & 51.9 & 1162 \\
\hline LFNOR09 & Landfill effluent & $<L O Q$ & 15.5 & 30.1 & 75.1 & 137 & 168 & 4.70 & 430 \\
\hline SENOR10 & Sewage effluent & $<L O Q$ & 2.60 & 1.80 & 6.89 & 14.5 & 20.2 & 3.55 & 49 \\
\hline SENOR11a & Sewage effluent & $<L O Q$ & 1.00 & 2.30 & 18.3 & 14.4 & 22.2 & 1.25 & 59 \\
\hline SENOR11b & Sewage effluent & $<L O Q$ & 1.32 & 2.27 & 16.7 & 13.9 & 22.5 & 1.34 & 58 \\
\hline SWDAN01 & Sea water & $<L O Q$ & 0.71 & 0.17 & 0.55 & 1.12 & 8.48 & 0.19 & 11 \\
\hline SWDAN02a & Sea water (sub-samples) & $<L O Q$ & 1.09 & 0.30 & 1.50 & 2.63 & 7.67 & 0.42 & 13 \\
\hline SWDAN02b & Sea water (sub-samples) & $<L O Q$ & 1.08 & 0.33 & 1.57 & 2.95 & 7.82 & 0.39 & 14 \\
\hline SWDAN03 & Sea water & $<\mathrm{LOQ}$ & 0.30 & 0.53 & 0.72 & 1.95 & 6.20 & 0.28 & 10 \\
\hline SWICE01a & Sea water (sub-samples) & $<L O Q$ & 0.05 & 0.08 & $<L O Q$ & 0.65 & 4.02 & 0.31 & 5 \\
\hline SWICE01b & Sea water (sub-samples) & $<L O Q$ & 0.08 & $<L O Q$ & $<\mathrm{LOQ}$ & 0.63 & 3.53 & 0.21 & 4 \\
\hline SWICE01C & Sea water (sub-samples) & $<L O Q$ & 0.06 & 0.08 & $<L O Q$ & 0.65 & 3.78 & 0.20 & 5 \\
\hline SWICE01d & Sea water (sub-samples) & $<L O Q$ & 0.06 & $<L O Q$ & $<L O Q$ & 0.73 & 3.83 & 0.21 & 5 \\
\hline
\end{tabular}




\begin{tabular}{|l|l|lrrrrrr|l|l|}
\hline Sample no. & Type & PFOSA & PFBS & PFHxS & PFOS & PFHxA & PFOA & PFNA & SUM \\
\hline SWFAR01 & Sea water & L LOQ & 0.06 & 0.08 & 0.31 & 0.59 & 3.62 & $<$ LOQ & 5 \\
SWFAR02 & Sea water & $<$ LOQ & 0.11 & 0.24 & 1.18 & 1.85 & 7.24 & $<$ LOQ & 11 \\
SWFAR03 & Sea water & $<$ LOQ & 0.05 & 0.08 & 0.52 & 0.81 & 4.67 & $<$ LOQ & 6 \\
SEFAR04 & Sewage effluent & $<$ LOQ & 0.20 & 0.26 & 1.22 & 1.61 & 1.26 & 0.44 & 5 \\
\hline
\end{tabular}

Biota [ng/g ww]

\begin{tabular}{|c|c|c|c|c|c|c|c|c|c|c|}
\hline Sample & Type & PFOSA & PFHxS & PFOS & PFHxA & PFOA & PFHpA & PFNA & PFDS & SUM \\
\hline PIFIN01 & Pike & 141 & 3.4 & 551 & $<$ LOD & 0.89 & $<$ LOD & 4.3 & 5.7 & 707 \\
\hline PIFIN02 & Pike & 62 & 2.1 & 440 & $<\mathrm{LOD}$ & $<\mathrm{LOD}$ & $<\mathrm{LOD}$ & 6.1 & 9.0 & 519 \\
\hline PIFIN03 & Pike & 61 & 2.3 & 204 & $<\mathrm{LOD}$ & $<$ LOD & 0.41 & 2.2 & 2.4 & 273 \\
\hline PIFIN04 & Pike & 70 & 1.3 & 211 & $<L O D$ & $<\mathrm{LOD}$ & $<L O D$ & 2.1 & 5.8 & 291 \\
\hline PIFIN05 & Pike & 115 & 1.8 & 240 & $<L O D$ & $<\mathrm{LOD}$ & $<$ LOD & 3.0 & 4.1 & 364 \\
\hline PIFIN06 & Pike & 139 & 1.4 & 263 & $<L O D$ & $<\mathrm{LOD}$ & $<$ LOD & 2.0 & 4.3 & 410 \\
\hline PIFIN07 & Pike & 92 & 1.4 & 253 & $<$ LOD & 1.42 & $<L O D$ & 1.5 & 5.1 & 354 \\
\hline PIFIN08 & Pike & 48 & 1.3 & 492 & $<$ LOD & $<\mathrm{LOD}$ & $<L O D$ & 1.9 & 6.2 & 549 \\
\hline PESWE01 & Perch & 0.60 & 1.4 & 172 & 1.08 & $<\mathrm{LOD}$ & $<L O D$ & 0.23 & $<L O D$ & 175 \\
\hline PESWE02 & Perch & 1.02 & $<L O D$ & 172 & 0.90 & $<\mathrm{LOD}$ & $<L O D$ & 0.63 & $<$ LOD & 174 \\
\hline PESWE03a & Perch & 5.5 & $<$ LOD & 427 & 0.66 & $<$ LOD & $<$ LOD & 1.5 & 3.6 & 438 \\
\hline PESWE03b & Perch & 6.1 & $<$ LOD & 432 & 0.62 & $<L O D$ & $<$ LOD & 1.3 & 3.2 & 443 \\
\hline
\end{tabular}




\begin{tabular}{|c|c|c|c|c|c|c|c|c|c|c|}
\hline Sample & Type & PFOSA & PFHxS & PFOS & PFHxA & PFOA & PFHpA & PFNA & PFDS & SUM \\
\hline PESWE04 & Perch & 2.17 & 0.79 & 169 & 0.66 & & 0.30 & 6.3 & $<\mathrm{LOD}$ & 179 \\
\hline COSWE05 & Cod & 0.85 & $<\mathrm{LOD}$ & 9.1 & $<\mathrm{LOD}$ & $<\mathrm{LOD}$ & $<L O D$ & 0.53 & $<\mathrm{LOD}$ & 10 \\
\hline COSWE06 & Cod & 0.41 & $<\mathrm{LOD}$ & 8.1 & $<$ LOD & $<\mathrm{LOD}$ & $<\mathrm{LOD}$ & 0.55 & $<\mathrm{LOD}$ & 9 \\
\hline COSWE07 & Cod & 0.75 & $<\mathrm{LOD}$ & 8.7 & $<$ LOD & $<\mathrm{LOD}$ & $<\mathrm{LOD}$ & 0.47 & $<\mathrm{LOD}$ & 10 \\
\hline COSWE08 & Cod & 1.16 & $<\mathrm{LOD}$ & 20 & $<\mathrm{LOD}$ & $<\mathrm{LOD}$ & $<L O D$ & 0.86 & 1.26 & 23 \\
\hline COSWE09 & Cod & 0.41 & $<\mathrm{LOD}$ & 6.4 & $<$ LOD & $<$ LOD & $<L O D$ & 0.94 & $<$ LOD & 8 \\
\hline COSWE10 & Cod & 0.48 & $<\mathrm{LOD}$ & 6.4 & $<$ LOD & $<\mathrm{LOD}$ & $<$ LOD & 0.55 & $<\mathrm{LOD}$ & 7 \\
\hline COSWE11 & Cod & 6.1 & $<\mathrm{LOD}$ & 23 & $<$ LOD & $<\mathrm{LOD}$ & $<\mathrm{LOD}$ & 9.0 & $<\mathrm{LOD}$ & 38 \\
\hline COSWE12 & Cod & 3.9 & $<\mathrm{LOD}$ & 62 & $<$ LOD & $<\mathrm{LOD}$ & $<\mathrm{LOD}$ & 18 & $<\mathrm{LOD}$ & 83 \\
\hline GSSWE13 & Grey seal & 15 & 2.0 & 537 & 0.62 & 0.6 & $<\mathrm{LOD}$ & 29 & 11 & 594 \\
\hline GSSWE14 & Grey seal & 7.5 & 0.67 & 422 & 0.48 & 1.4 & $<\mathrm{LOD}$ & 36 & 13 & 481 \\
\hline GSSWE15 & Grey seal & 17 & 1.1 & 331 & 0.62 & 1.8 & $<$ LOD & 35 & 9 & 395 \\
\hline BUNOR01 & Burbot & 14 & $<\mathrm{LOD}$ & 8.1 & $<L O Q$ & $<\mathrm{LOD}$ & $<$ LOD & $<$ LOD & 1.9 & 24 \\
\hline TRNOR02 & Trout & 35 & $<\mathrm{LOD}$ & 51 & 0.86 & $<$ LOD & $<L O D$ & 2.7 & 5.6 & 95 \\
\hline PINOR03 & Pike & 60 & $<\mathrm{LOD}$ & 24 & 1.1 & $<\mathrm{LOD}$ & $<\mathrm{LOD}$ & 1.1 & 4.2 & 90 \\
\hline PENOR04 & Perch & 11 & $<$ LOD & 120 & 1.49 & $<\mathrm{LOD}$ & 0.57 & 4.5 & 4.0 & 141 \\
\hline FLDAN01 & Flounder & 3.3 & $<$ LOD & 20 & 0.74 & $<\mathrm{LOD}$ & $<\mathrm{LOD}$ & 0.78 & $<\mathrm{LOD}$ & 25 \\
\hline FLDAN02 & Flounder & 3.8 & $<$ LOD & 19 & $<$ LOD & $<$ LOD & $<\mathrm{LOD}$ & 1.3 & $<\mathrm{LOD}$ & 25 \\
\hline FLDAN03 & Flounder & 14.6 & $<\mathrm{LOD}$ & 21 & $<$ LOD & $<\mathrm{LOD}$ & $<\mathrm{LOD}$ & 0.95 & $<\mathrm{LOD}$ & 36 \\
\hline FLDAN04 & Flounder & 4.7 & $<\mathrm{LOD}$ & 18 & $<$ LOD & $<\mathrm{LOD}$ & $<$ LOD & 0.92 & $<\mathrm{LOD}$ & 24 \\
\hline EPDAN05 & Eelpout & 7.5 & $<$ LOD & 60 & 0.90 & 1.02 & $<$ LOD & 2.1 & 2.6 & 74 \\
\hline HEDAN06 & Herring & 19.2 & 0.42 & 15 & 0.66 & 5.4 & $<$ LOD & 1.2 & $<$ LOD & 42 \\
\hline
\end{tabular}




\begin{tabular}{|c|c|c|c|c|c|c|c|c|c|c|}
\hline Sample & Type & PFOSA & PFHxS & PFOS & PFHxA & PFOA & PFHpA & PFNA & PFDS & SUM \\
\hline HSDAN07 & Harbour seal & 4.1 & 10 & 772 & 1.4 & 5.0 & 0.4 & 11.5 & $<\mathrm{LOD}$ & 805 \\
\hline HSDAN08 & Harbour seal & 0.93 & 8.0 & 762 & 1.0 & 5.6 & $<$ LOD & 11.1 & $<$ LOD & 789 \\
\hline HSDAN09 & Harbour seal & 55 & 5.3 & 892 & 3.5 & 0.3 & $<\mathrm{LOD}$ & 2.5 & 2.4 & 961 \\
\hline HSDAN10 & Harbour seal & 46 & 10 & 977 & 3.2 & 1.3 & $<$ LOD & 9.0 & 13 & 1060 \\
\hline HSDAN11 & Harbour seal & 11 & 5.0 & 565 & 1.2 & 1.1 & 0.5 & 8.1 & 10 & 602 \\
\hline LDICE01a & Long rough dab & $<$ LOD & $<\mathrm{LOD}$ & 13 & 4.2 & $<\mathrm{LOD}$ & $<L O D$ & 1.26 & 11.6 & 31 \\
\hline LDICE01b & Long rough dab & $<$ LOD & $<$ LOD & 12 & 5.9 & $<\mathrm{LOD}$ & 0.56 & 1.26 & 6.8 & 26 \\
\hline LDICE01C & Long rough dab & $<L O D$ & $<$ LOD & 28 & 9.6 & $<$ LOD & 1.8 & 1.44 & 6.8 & 48 \\
\hline LDICE02 & Long rough dab & $<L O D$ & $<$ LOD & 19 & $<$ LOD & $<$ LOD & $<\mathrm{LOD}$ & $<$ LOD & 10.7 & 30 \\
\hline SCICE03 & Sculpin & 30 & $<\mathrm{LOD}$ & 19 & 11 & $<$ LOD & $<\mathrm{LOD}$ & $<$ LOD & 6.8 & 67 \\
\hline DAICE04 & Dab & $<$ LOD & $<$ LOD & 17 & $<$ LOD & $<$ LOD & $<\mathrm{LOD}$ & $<$ LOD & 9.7 & 27 \\
\hline MWICE05 & Minke whale & 13 & $<\mathrm{LOD}$ & 19 & 0.94 & $<\mathrm{LOD}$ & $<\mathrm{LOD}$ & 1.1 & 3 & 37 \\
\hline MWICE06 & Minke whale & 12 & $<$ LOD & 28 & 0.90 & $<\mathrm{LOD}$ & 0.23 & 1.6 & 4 & 47 \\
\hline MWICE07 & Minke whale & 7.2 & 1.1 & 21 & 0.94 & $<$ LOD & $<\mathrm{LOD}$ & 1.1 & 4 & 35 \\
\hline MWICE08 & Minke whale & 19 & $<$ LOD & 71 & 0.68 & $<$ LOD & $<\mathrm{LOD}$ & 2.3 & 5 & 98 \\
\hline MWICE09 & Minke whale & 14 & $<\mathrm{LOD}$ & 67 & 0.99 & $<\mathrm{LOD}$ & $<\mathrm{LOD}$ & 2.4 & 5 & 89 \\
\hline SCFAR01 & Sculpin & 3.4 & $<\mathrm{LOD}$ & 2.0 & $<$ LOD & $<\mathrm{LOD}$ & $<\mathrm{LOD}$ & $<\mathrm{LOD}$ & $<$ LOD & 5 \\
\hline SCFAR02 & Sculpin & 5.8 & $<\mathrm{LOD}$ & 2.5 & $<\mathrm{LOD}$ & $<\mathrm{LOD}$ & $<L O D$ & $<$ LOD & $<$ LOD & 8 \\
\hline DAFAR03 & Dab & 0.21 & $<\mathrm{LOD}$ & 2.1 & $<$ LOD & $<$ LOD & $<\mathrm{LOD}$ & $<$ LOD & $<$ LOD & 2 \\
\hline DAFAR04 & Dab & 0.36 & $<\mathrm{LOD}$ & 1.3 & $<$ LOD & $<\mathrm{LOD}$ & $<\mathrm{LOD}$ & $<\mathrm{LOD}$ & $<\mathrm{LOD}$ & 2 \\
\hline COFAR05 & Cod & 4.5 & $<\mathrm{LOD}$ & 0.85 & $<$ LOD & $<\mathrm{LOD}$ & $<\mathrm{LOD}$ & $<\mathrm{LOD}$ & $<\mathrm{LOD}$ & 5 \\
\hline ACFAR06a & Arctic char & 4.2 & $<\mathrm{LOD}$ & 4.8 & $<$ LOD & $<\mathrm{LOD}$ & $<\mathrm{LOD}$ & $<$ LOD & $<$ LOD & 9 \\
\hline
\end{tabular}




\begin{tabular}{|l|l|lllllllll|l|}
\hline Sample & Type & PFOSA & PFHxS & PFOS & PFHxA & PFOA & PFHpA & PFNA & PFDS & SUM \\
\hline ACFAR06b & Arctic char & 5.7 & $<$ LOD & 5.3 & LLOD & $<$ LOD & $<$ LOD & $<$ LOD & $<$ LOD & 11 \\
ACFAR07 & Arctic char & 3.6 & $<$ LOD & 4.7 & $<$ LOD & $<$ LOD & $<$ LOD & $<$ LOD & $<$ LOD & 8 \\
PWFAR08 & Pilot whale & 218 & 0.66 & 88 & 0.53 & 0.45 & $<$ LOQ & 5.5 & 11 & 324 \\
PWFAR09 & Pilot whale & 364 & 0.39 & 136 & 1.00 & 0.35 & $<$ LOQ & 5.4 & 12 & 519 \\
PWFAR10 & Pilot whale & 184 & 0.52 & 256 & 0.89 & 1.7 & $<$ LOQ & 17 & 27 & 486 \\
PWFAR11 & Pilot whale & 172 & 1.0 & 336 & 0.84 & 1.3 & $<$ LOQ & 20 & 30 & 560 \\
FUFAR12 & Fulmar pool1 & LLOD & $<$ LOD & 31 & $<$ LOD & $<$ LOD & 0.4 & 1 & $<$ LOD & 33 \\
FUFAR13 & Fulmar pool2 & 0.46 & $<$ LOD & 37.5 & $<$ LOD & $<$ LOD & 0.45 & 1.3 & $<$ LOD & 40 \\
\hline
\end{tabular}




\section{Appendix 4: Sampling locations}

\section{Sample locations:}

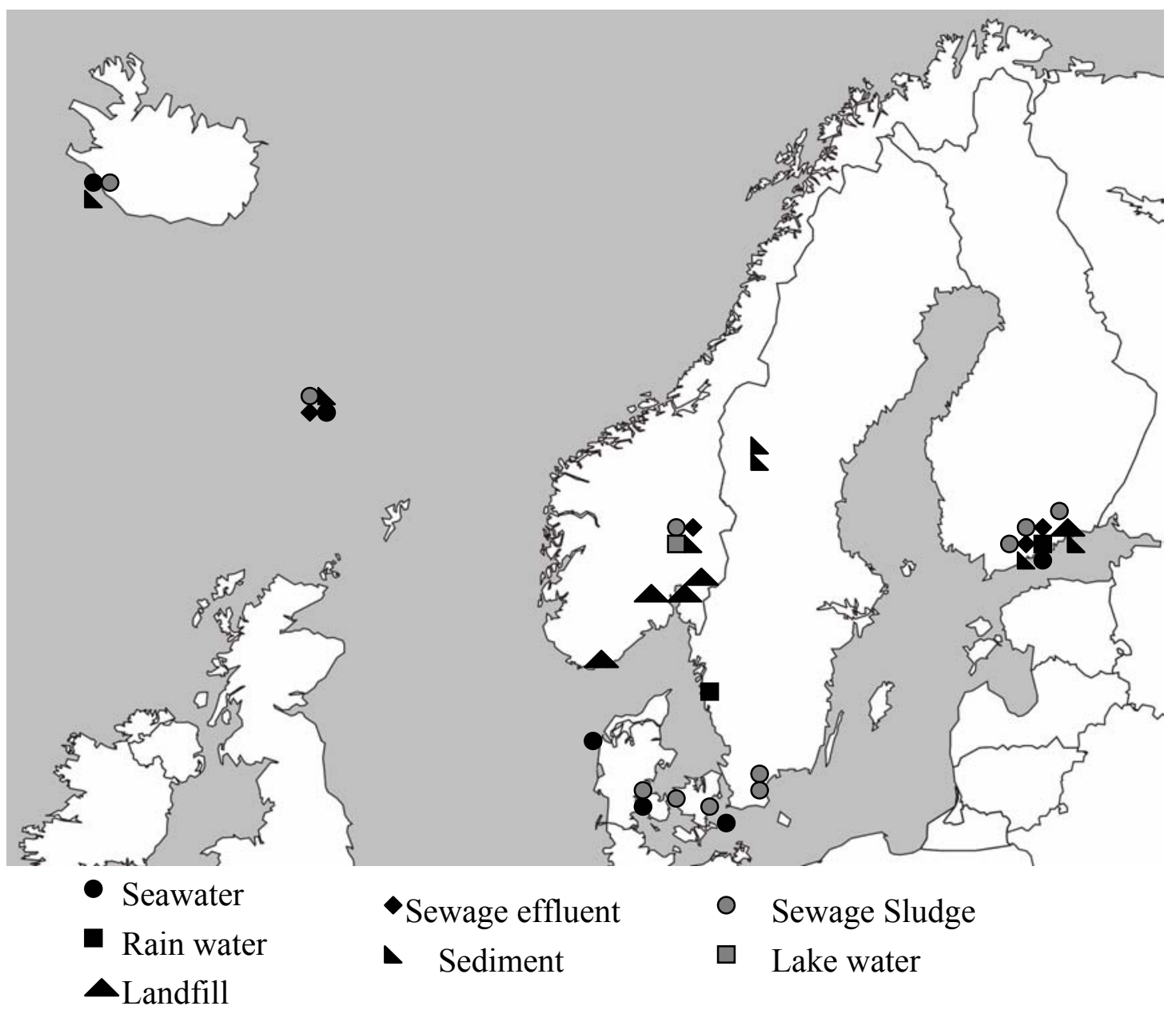




\section{Sample locations: Biota}

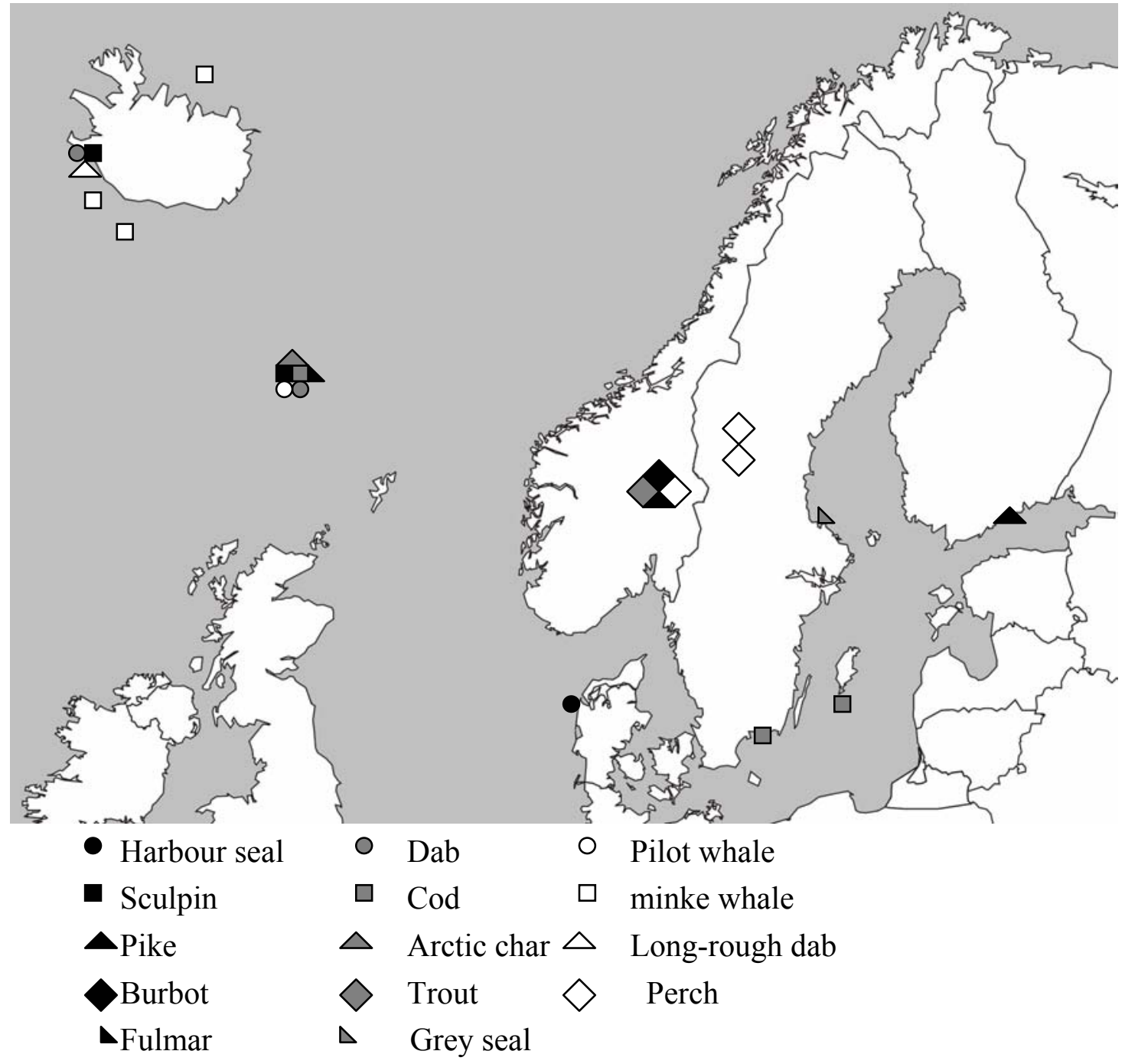




\section{Appendix 5: Abbreviations list}

\begin{tabular}{|c|c|}
\hline Abbreviation & Explanation \\
\hline AHTN & Polycyclic musk, Tonalide \\
\hline ASE & Accelerated Solvent extraction \\
\hline ECF & Electrochemical fluorination \\
\hline EPA & U.S. Environmental Protection Agency \\
\hline DEFRA & UK Department for Environment; Food and Rural Affairs \\
\hline $\mathrm{EC}_{50}$ & $\begin{array}{l}\text { Cncentration of an agonist, which produces } 50 \% \text { of the maximum } \\
\text { possible response for that agonist in a test population. }\end{array}$ \\
\hline ESI & Electrospray ionisation \\
\hline FTOH & Fluoro-telomer alcohols \\
\hline $\mathrm{HCB}$ & Hexachlorobenzene \\
\hline $\mathrm{HCH}$ & hexachlorocyclohexane \\
\hline HHCB & Polycyclic musk, Galaxolide \\
\hline HPLC & High performance liquid chromatography \\
\hline ITM & $\begin{array}{l}\text { Institute of Applied Environmental Research (Stockholm University, } \\
\text { Sweden) }\end{array}$ \\
\hline ISTD & Internal standard \\
\hline $\mathrm{K}_{\mathrm{OW}}$ & Octanol-water partitioning coefficient \\
\hline $\mathrm{LC}_{50}$ & Lethal concentration for $50 \%$ of the test population \\
\hline LOD & Limit of detection \\
\hline LOEC & Lowest observed effect concentration \\
\hline LOQ & Limit of quantification \\
\hline LLOQ & Lowest limit of quantification \\
\hline NDFDA & nonadecafluoro- $n$-decanoic acid \\
\hline NILU & Norwegian Institute for Air Research \\
\hline NIVA & Norwegian Institute for Water Research \\
\hline NOAEL & No observed adverse effect level \\
\hline NOEC & No observed effect concentration \\
\hline NOEL & No observed effect limit \\
\hline NTEM & Nordic Terrestrial Monitoring Group \\
\hline PFAS & Perfluorinated alkylated substances \\
\hline PBDE & Polybrominated diphenyl ethers \\
\hline $\mathrm{PCDD} / \mathrm{F}$ & Chlorinated- $p$-dibenzodioxins and furans \\
\hline peq & person equivalent (contribution to sewage) \\
\hline
\end{tabular}




\begin{tabular}{|l|l|}
\hline Abbreviation & Explanation \\
\hline PET & Polyethylene \\
\hline PP & Polypropylene \\
\hline RSTD & Recovery standard (volume standard) \\
\hline SFT & $\begin{array}{l}\text { Statens forurensningstilsynet (Norwegian State Pollution Control } \\
\text { Authorities) }\end{array}$ \\
\hline SRM & Selected reaction monitoring \\
\hline STP & Sewage treatment plant \\
\hline TOF & Time-of-flight mass spectrometry \\
\hline UNEP & United Nations Environmental Programme \\
\hline
\end{tabular}




\section{BELGIEN \& LUXEMBOURG}

Jean de Lannoy

Avenue du Roi, 202, 1190 Brussels

Tel +32 (0)2 5385169

Fax +32 (0)2 5380841

jean.de.lannoy@euronet.be

\section{CANADA}

Renouf Publishing Company Ltd

5369 Canotek Road, Ottawa,

Ontario K1J 9J3

$\mathrm{Tel}+1$ (613) 7452665

Fax + 1 (613) 7457660

order.dept@renoufbooks.com

www.renoufbooks.com

\section{DANMARK}

Svensk-Norsk Bogimport A/S

Esplanaden 8 B, 1263 København K $\mathrm{Tel}+4533142666 \mathrm{Fax}+4533143588$ snb@bog.dk

www.snbog.dk

\section{ESTLAND}

Astro Raamatud AS

Pärnu mnt 142, 11317 Tallinn

Tel +372 6548485 Fax +372 6548475

book@astro.ee

\section{FINLAND}

Akademiska Bokhandeln

PB 128, Centralgatan 1,

00101 Helsingfors

Tel +358 912141

akatilaus@akateeminen.com

www.akateeminen.com

\section{FRANKRIG}

Librairie LAVOISIER

14, rue de Provigny,

94236 Cachan Cedex

Tel +33 (1) 47406700

Fax +33 (1) 47406702

group@lavoisier.fr

www.lavoisier.fr

\section{F/ERøERNE}

H.N. Jacobsens Bókahandil

Postboks 55, 110 Tórshavn

Tel +29831 1036 Fax +298317873

hnj@hnj.fo

www.hnj.fo

\section{HOLLAND}

De Lindeboom Internationale Publicaties

M.A. de Ruyterstraat 20 A,

NL-7482 BZ Haaksbergen

Tel +31 (0)535740004

Fax +31 (0)53 5729296

books@delindeboom.com

www.delindeboom.com

\section{ISLAND}

Mál og Menning

Laugavegi 18, 101 Reykjavik

Tel +354 (9)5152500

Fax +354 (9)515 2505

books@penninn.is

\section{KINA}

CNPIEC

Europe Division 16 Gongti East Road

P.O. Box 88, Beijing

Tel +86 $105066688-8$

Fax +86105063101

\section{LETLAND}

Jana Rozes Gramàtnica

Kr. Barona iela 5, 1011 Riga

$\mathrm{Tel}+371$ (0)2 284288

Fax +3717370922

\section{LITAUEN}

Penki Kontinentai

A. Stulginskio 5, 2001 Vilnius

Tel +370 (5) 2664540

Fax +370 (5) 2664565

books@5ci.lt

www.books.lt

\section{NORGE}

Akademika A/S

Postboks 84 Blindern, 0314 Oslo

Tel +4722 $853030 \mathrm{Fax}+4722853080$

bloken@sio.uio.no

www.akademika.no

\section{RUMAENIEN}

Euromedia s.r.l.

Str Dionisie Lupu nr 65, 70184 Bucuresti

$\mathrm{Tel}+4016140664$

Fax +4013129646

\section{STORBRITANNIEN}

The Stationery Office

P.O. Box 276, London SW8 5DT

Tel +448706005522

Fax +448706005533

customer.services@tso.co.uk

www.tso.co.uk/bookshop

\section{SVERIGE}

Fritzes

Kundservice, 10647 Stockholm

Tel +46 (0)8 6909190

Fax +46 (0)8 6909191

order.fritzes@nj.se

www.fritzes.se

\section{TYSKLAND}

UNO-Verlag GmbH

Am Hofgarten 10, 53113 Bonn

Tel +49 (0)228949020

Fax +49 (0)228 9490222

info@uno-verlag.de

www.uno-verlag.de

\section{UNGARN}

Euro Info Service

PO Box 1039, 1245 Budapest

Tel +36 (1) 3292487

Fax +36 (1) 3492053

euroinfo@euroinfo.hu

USA

Bernan

4611-F Assembly Drive,

Lanham MD 20706-4391

Tel +1 (301) 4597666

$\mathrm{Fax}+1$ (301) 4590056

query@bernan.com

www.bernan.com

\section{ÅLAND}

Lisco bok- och pappershandel Skarpansvägen 25, Box 8 , 22101 Mariehamn Tel +358 (0)1817177 Fax +358 (0)18 19771 info@lisco.fi 